\author{
UNIVERSIDADE DE SÃO PAULO \\ FACULDADE DE ARQUITETURA E URBANISMO
}

DOUGLAS LOPES DE SOUZA

\title{
A Configuração do Discurso do Diagrama na Arquitetura Contemporânea
}


A Configuração do Discurso do Diagrama na Arquitetura Contemporânea

Douglas Lopes de Souza

Dissertação apresentada à Faculdade de Arquitetura e Urbanismo da Universidade de São Paulo para obtenção do título de Mestre em Arquitetura e Urbanismo.

Área de Concentração:

Design e Arquitetura

Orientador: Prof. Dr. Carlos Egídio Alonso

São Paulo

2010 
AUTORIZO A REPRODUÇÃO E DIVULGAÇÃO TOTAL OU PARCIAL DESTE TRABALHO, POR QUALQUER MEIO CONVENCIONAL OU ELETRÔNICO, PARA FINS DE ESTUDO E PESQUISA, DESDE QUE CITADA A FONTE.

E-MAIL: DGLOPES@GMAIL.COM

Souza, Douglas Lopes de

S729a A configuração do discurso do diagrama na arquitetura contemporânea / Douglas Lopes de Souza. --São Paulo, 2010. 139 p. : il.

Dissertação (Mestrado - Área de Concentração: Design e Arquitetura) - FAUUSP.

Orientador: Carlos Egídio Alonso

1.Teoria da arquitetura 2.Projeto de arquitetura I.Título

CDU 72.01 
Nome: SOUZA, Douglas Lopes de.

Título: A Configuração do Discurso do Diagrama na Arquitetura Contemporânea

Dissertação apresentada à Faculdade de Arquitetura e Urbanismo para obtenção de título de Mestre em Arquitetura

Aprovado em:

Banca Examinadora

Prof. Dr. Instituição:

Julgamento: Assinatura:

Prof. Dr. Instituição:

Julgamento: Assinatura:

Prof. Dr. Instituição:

Julgamento: Assinatura: 
A meus pais, Moacil e Ruth. 


\section{AGRADECIMENTOS}

Este trabalho não teria sido possível sem a aceitação, disponibilidade, e orientação do Prof. Dr. Carlos Egídio Alonso, por sua amizade e suas exposições sempre estimulantes e motivadoras despertadas durante o processo.

Aos membros da banca do exame de qualificação, Prof. Dr. Ricardo Marques de Azevedo e Prof. Dr. David Moreno Sperling que, através de apontamentos preciosos, permitiram que esta dissertação enveredasse pelos caminhos apropriados.

Ao Prof. Dr. Wilson Flório pelos ensinamentos sobre arquitetura contemporânea, disponibilidade e precisão nas orientações deste trabalho.

Aos professores Luis Antônio Jorge, Giorgio Giorgi Júnior, Cibele Haddad e Cristiane Aun, pela recepção acolhedora dentro da disciplina de Design do Objeto em meu estágio docente.

Aos professores da Universidade Federal de Minas Gerias, José dos Santos Cabral Filho e Celina Borges Lemos, por implantarem em mim o vírus da pesquisa.

À equipe bibliotecária da FAU: Maria José, Estelita, Regina e Ana Paula pela atenção e simpatia que recebi no auxílio em minhas pesquisas.

Aos meus pais, Moacil e Ruth, ao me incentivarem e mostrarem direções em momentos difusos.

À minha irmã Adriana pelo duplo apoio e confiança que recebi no percurso, sobretudo, pelo seu exemplo.

À minha irmã Nádia pelo trabalho logístico sempre eficiente em Viçosa e pela sua alegria contagiante.

Aos meus amigos, Vinícius, Leandro, Thiago, Bruno e Pedro pelo desfocamento da pesquisa em momentos importantes.

Aos mestrandos Verônica Natividade, Elenira Arakilian, Hermínia Machry, Felipe Lima, André Lacroce e Pedro Veloso pelas conversas e discussões sobre a vida, a FAU e tudo mais.

E a Michele Mello por sua atenção, carinho e apoio constante. Sem sua companhia e amor este trabalho teria sido muito mais árduo. 
"Technology is the answer... but what was the question?" Cedric Price (1979) 


\section{RESUMO}

Frente a uma compreensão projetual ampliada na arquitetura contemporânea devido às intersecções disciplinares experimentadas no pós-modernismo, esta pesquisa destaca os processos que anunciam o diagrama como conceito que efetiva um novo modus operandi arquitetônico.

Percebendo as ramificações teóricas que são geradas sobre este tema dentro do discurso dos arquitetos, este trabalho busca na definição semiótica de diagrama em Charles S. Peirce e na sua derivação filosófica em Gilles Deleuze e Félix Guattari um suporte instrumental para a compreensão da configuração do discurso do diagrama na arquitetura.

Partindo do pressuposto que a possibilidade de um conceito só é efetivada em sua interpretação, recorremos à análise de textos e obras de Peter Eisenman e do escritório UNStudio na tentativa de compreender como o conceito transita nestas arquiteturas.

Palavras-chave:

Diagrama, arquitetura contemporânea, teoria da arquitetura 


\section{ABSTRACT}

Facing an amplified projectual comprehension in contemporary architecture due to the disciplinary intersections experimented in the postmodernism, this thesis emphasize the processes that announce the diagram as a concept that effects a new architectural modus operandi.

Apprehending the theoretical ramifications that are generated about this theme inside the architect's speeches, this thesis searches in the Charles S. Peirce's semiotics definition of diagram and in its philosophic derivation of Gilles Deleuze and Félix Guattari an instrumental support for the comprehension of the dis- course 's configuration of the diagram in architecture.

Starting from the assumption that the possibility of a concept is only effective inner its interpretation, we had recoursed to the analysis of texts and works of Peter Eisenman and of the office UNStudio in the attempt to understand how the concept transits in these 


\section{ILUSTRAÇOES}

\section{Capítulo 1}

Figura 1.1 Composição de Modelos Geométricos e Formas Simples

Fonte: PAI, Hyungmin, 2002.

Figura 1.2 Análise do movimento

Fonte: PAl, Hyungmin, 2002.

Figura 1.3 Mapa de supervisão funcional 25

Fonte: PAl, Hyungmin, 2002.

Figura 1.4 Registro do movimento através do método ciclográfico 26

Fonte: PAI, Hyungmin, 2002.

Figura 1.5 Procedimentos necessários para fazer um bolo 27 Fonte: PAl, Hyungmin, 2002.

Figura 1.6 Estudos de Eficiência Alemães 28

Fonte: PAl, Hyungmin, 2002.

Figura 1.7 Projeto de Residência. George Howe, 1936 29

Fonte: PAl, Hyungmin, 2002.

Figura 1.8 Geometria da Figura Humana 30

Fonte: PAl, Hyungmin, 2002.

Figura 1.9 Mapeamento do movimento ao deitar. Análise da altura livre

Fonte: PAl, Hyungmin, 2002.

Figura 1.10 Projeto para o Museu da Ciência.

Fonte: PAl, Hyungmin, 2002.

Figura 1.11 Metodologia de projeto a partir da composição de blocos

Fonte: PAl, Hyungmin, 2002.

Figura 1.12 Unidades habitacionais funcionais

Fonte: PAI, Hyungmin, 2002.

\section{Capíutlo 2}

Figura 2.1 Diagrama de Euler

Fonte: elaborado pelo autor

Figura 2.2 Aplicação das regras de composição.

Fonte: elaborado pelo autor

Figura 2.3 Operações lógicas 50

Fonte: elaborado pelo autor 


\section{Capítulo 3}

Figura 3.1 Panóptico

Fonte: PAl, Hyungmin, 2002.

Figura3.2 Três estudos para um auto-retrato. Francis Bacon 1979

Fonte: http://www.arcadja.com/artmagazine/it/2008/05/16/i-top-lot-della-settimana-8/

\section{Capítulo 4}

Figura 4.1 Villa Rotonda.

Fonte: ROWE, Colin, 1987.

Figura 4.2 Villa Cornaro

Fonte: ROWE, Colin, 1987.

Figura 4.3 Desenhos de Villard d'Hounnecourt.

Fonte: BECHMANN, Roland, 1993.

Figura 4.4 Casa II

Fonte: DAVIDSON, Cyntia, 2006.

Figura4.5 Casa IV

Fonte: DAVIDSON, Cyntia, 2006.

Figura 4.6 Casa IV

Fonte: DAVIDSON, Cyntia, 2006.

Figura 4. 7 Casa 11a

Fonte: DAVIDSON, Cyntia, 2006.

Figura 4.8 Cannaregio

Fonte: DAVIDSON, Cyntia, 2006.

Figura 4.9 Casa 11a

Fonte: EISENMAN, Peter, 1999.

Figura 4.10 Romeo + Juliete 103

Fonte: DAVIDSON, Cyntia, 2006.

Figura 4.11 Sobreposição de plantas 103

Fonte: DAVIDSON, Cyntia, 2006.

Figura 4.12 Biocentro

Fonte: DAVIDSON, Cyntia, 2006.

Figura 4.13 Implantação do projeto Igreja do ano 2000 106

Fonte: DAVIDSON, Cyntia, 2006.

Figura 4.14 Fases do cristal líquido. 107

Fonte: elaborado pelo autor

Figura 4.15 Igreja do ano 2000 109

Fonte: DAVIDSON, Cyntia, 2006.

Figura 4.16 Modelo final 110

Fonte: DAVIDSON, Cyntia, 2006. 


\section{Capítulo 5}

Figura 5.1 Modelo de Möebius.

Fonte: VAN BERKEL; BOS, 2006.

Figura 5.2 Plantas

Fonte: VAN BERKEL; BOS, 2006.

Figura 5.3 UCP Mainport 123

Fonte: VAN BERKEL; BOS, 1999.

Figura 5.4 Planejamento Urbano em Nieuwegein 123

Fonte: VAN BERKEL; BOS, 1999.

Figura 5.5 UCP Mainport, Utrecht, 1997 124

Fonte: VAN BERKEL; BOS, 1999.

Figura 5.6 Modelo do UCP Mainport 125

Fonte: VAN BERKEL; BOS, 1999.

Figura 5.7 Garrafa de Klein 126

Fonte: VAN BERKEL; BOS, 2006. 
Sumário

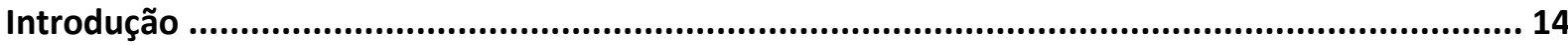

Capítulo 1

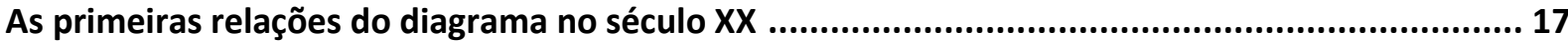

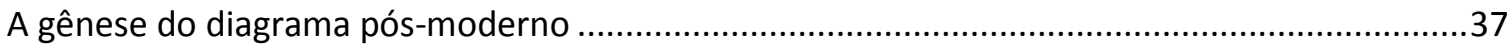

Capítulo 2

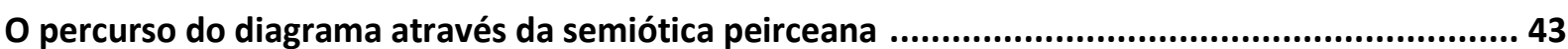

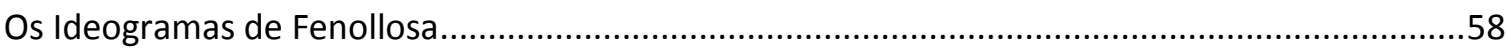

Capítulo 3

A visão do diagrama pela filosofia de Deleuze e Guattari ...................................................63

Capítulo 4

O território da escrita de Peter Eisenman ......................................................................... 76

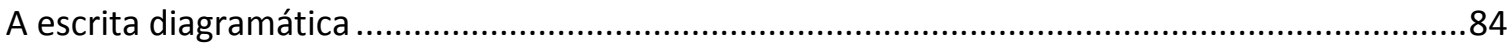

Capítulo 5

UNStudio e a potência diagramática

Considerações Finais

Bibliografia 


\section{Introdução}

A arquitetura está amplamente permeada pelo contato tecnológico. Durante a década de 80 , a questão sobre a validade do uso de meios digitais para produção de arquitetura acabou por obter sua resposta nos anos seguintes. Os procedimentos computacionais possíveis evoluíram à medida que os arquitetos lançavam sobre a ferramenta questões arquitetônicas com relação à produção do espaço e a presença da arquitetura em eras dinâmicas. As novidades freqüentes que apareciam nas obras de arquitetura, ligadas ao livre arbítrio arquitetônico, promoveram certa expansão e sedução por parte destes mecanismos digitais.

Ao mesmo tempo, a arquitetura carente de um solo firme, se lança nas discussões lingüísticas para, em seguida, romper qualquer vínculo rígido, derivar-se em vetores que incorporavam essa condição indefinida da disciplina.

Assim, os processos de pensar a obra da arquitetura estavam mudando e, conseqüentemente (ou paralelamente), o meio para se pensar essa arquitetura. Um dos processos era voltado para o estudo de informações do terreno e do programa de uma maneira sistemática, usando as possibilidades geradas pelo computador para transformar estes dados em matéria, em arquiteturas ao mesmo tempo que tenta retirar a intenção do arquiteto sobre o projeto. Muitos chamaram esse processo de construção de mapas de informação como diagramático.

O trabalho que segue é baseado em uma questão: o que é um diagrama, e mais precisamente, como ele se define na arquitetura?

Vemos, principalmente nos anos 90, uma grande apropriação do termo diagrama na disciplina de arquitetura por vários motivos, dentre os quais a evolução de um raciocínio que tenta buscar fora da disciplina aparato estável para a prática arquitetônica. 
Deste modo, percebemos uma assimilação de conceitos filosóficos no entendimento do conceito diagramático, gerando $\mathrm{o}$ conceito de diagrama proliferativo que transcende a simples explicação de fatos.

Compete à crítica não obedecer a uma ou mais teorias, mas relacioná-las e problematizá-las. Assim, ao problematizarmos o tema do diagrama com o intuito de procurar uma série de relações deste tema dentro de um conjunto teórico, o fazemos através da compreensão do movimento do diagrama no interior dos discursos de Peter Eisenman e do escritório UNStudio. Na eleição dos conceitos conectados ao diagrama, outros são trazidos como uma rede (ou rizoma). Cabe a essa dissertação expor uma das relações possíveis deste complexo conceitual.

$\mathrm{Na}$ possibilidade de comparar os conceitos de diagrama trazidos pelos arquitetos, é invocada a teoria semiótica de Charles Sanders Peirce e Fenollosa com a finalidade de trazer a este complexo conceitual, o desenvolvimento de uma visão sígnica sobre a relação diagramática.

Essa dissertação se estrutura da seguinte forma:

No primeiro capítulo trazemos uma análise do percurso do conceito de diagrama como ferramenta projetiva iniciado na modernidade do século XX e que se desenvolve através do pós-modernismo para, enfim, acontecer na contemporaneidade.

Já no seguinte, trazemos dois outros capítulos que instrumentalizarão nossa crítica acerca do diagrama.

A semiótica de Charles Sanders Peirce será trazida a este trabalho por sua interpretação triádica: índice, ícone e símbolo. Essa interpretação, além de ser instrumentalizadora para leitura de textos posteriores, tem seu valor ampliado no momento que Peirce define o diagrama como um "ícone relacional". Percebemos a ressonância que tal tema desenvolve em vários campos e expressões, de modo que apresentamos sua interpretação em Haroldo de Campos sobre os ideogramas de Fenollosa (1853-1908).

Apropriadamente, os conceitos desenvolvidos por Campos são continuados no capítulo seguinte, também base para nossa leitura: uma visão do diagrama pela 
filosofia de Gilles Deleuze e Félix Guattari. Por mais absurdo que pareça agenciar um texto do fim do século $X I X$ com outro do fim do século $X X$, mostraremos que a questão temporal, neste caso, não é um critério. Se esse texto de Fenollosa possui força suficiente para atravessar décadas e significar além de seu tempo, será mostrado neste terceiro capítulo, onde expomos brevemente tanto o ambiente social complexo onde são desenvolvidas as teorias de Deleuze e Guattari como também alguns de seus entendimentos, relacionando-os sob o tema da máquina abstrata.

A partir deste momento iniciamos a segunda etapa deste trabalho que é a consideração do conceito de diagrama dentro da arquitetura. Como é desenvolvido o discurso do diagrama na arquitetura contemporânea? Sabendo que um conceito só pode ser perfeitamente entendido dentro de sua potencialidade instaurada, fizemos a escolha por dois discursos: o de Peter Eisenman e o do escritório UNStudio.

Eisenman, particularmente, é mostrado através da evolução de sua teoria nos anos 60 a partir de seu estudo do arquiteto italiano Giuseppe Terragni, passando pelas variações sígnicas da lingüística e atravessando o pós-modernismo em sua busca pela definição da interioridade da arquitetura. Para tanto, inicialmente ele traz conceitos da lingüística e a questiona em seguida, com o apoio de Derrida.

Já no quinto capítulo trazemos a "geração recente" do diagrama, tal como Eisenman a qualifica. O escritório UNStudio desenvolve uma interpretação do conceito de diagrama pelo tema da máquina abstrata que explicitaremos no terceiro capítulo.

Com isso, percebemos diferenças conceituais entre os dois arquitetos escolhidos, mas essa diferença teórica já era esperada. O que move este trabalho é a percepção de certa desordem argumentativa na avaliação de temas que surgem através do conceito de diagrama. Uma desordem que pode ter sido gerada pelas relações criadas em outras disciplinas, como a semiótica e a filosofia.

Cabe a esta pesquisa, despretensiosamente, o mapeamento dos conceitos e das relações estabelecidas, com o intuito de trazer uma contribuição à discussão do tema na arquitetura. 
[Análise do conceito de diagrama na História] 


\section{CAPÍTULO 1 - As primeiras relações do diagrama no século XX.}

Apesar de este capítulo expor uma descrição temporal da evolução do uso de diagramas em arquitetura, uma tentativa de promover uma historiografia se perde quando consideramos o diagrama como um conceito genérico e amplo. A pertinência de um projeto para achar a 'origem' do diagrama arquitetônico depende de como ele é definido e poderia dizer que o conceito mais amplo de diagrama arquitetônico inexiste, uma vez que passa a ser conceito puro e foge do campo da arquitetura para se instaurar, quem sabe, na filosofia.

A tentativa, neste momento, é de estabelecer uma base teórica para a análise de textos futuros e contemporâneos que mencionam o termo diagrama. Tomando a premissa de que um conceito é gerado de uma condição existente, o texto que se segue foi construído de uma análise do discurso da disciplina arquitetura identificando o início do século XX como instaurador de novos paradigmas que criaram tensões na disciplina e na profissão. Através destas tensões, novos entendimentos emergiram e, conseqüentemente, novas linguagens, dentre as quais o diagrama funcional vinculado à produção industrial e possivelmente reinterpretado nos períodos seguintes.

Partiremos do estudo da modernidade científica, no início do século $X X$, tomada como ponto de inflexão do pensamento que passa a se relacionar com outros fatores sociais e assimilá-los dentro de seu saber.

\footnotetext{
"Hegel emprega o conceito de modernidade, antes de tudo, em contextos históricos, como conceito de época: os 'novos tempos' são 'tempos modernos'(...) [que] por volta de 1800 designavam os três séculos precedentes. A descoberta do 'Novo Mundo' assim como o Renascimento e a Reforma, os três grandes acontecimentos por volta de 1500, constituem o limiar histórico entre a época moderna e medieval". 1
}

O termo Zeitgeist (espírito da época ou espírito dos tempos) caracteriza uma transição temporal e do pensamento baseada na consciência da aceleração e em uma expectativa do novo, do diferente que há no futuro ${ }^{2}$. Esse espírito de mudança, de instauração de uma nova temporalidade, passa a ser uma engrenagem

\footnotetext{
${ }^{1}$ HABERMAS, 2002, p. 9.

${ }^{2}$ HABERMAS, 2002, p. 10.
} 
fundamental no entendimento da modernização no início do século XX e proverá os questionamentos necessários para a estratificação da disciplina arquitetônica.

É no ano de 1924, época marcada pelo pensamento sobre ecletismo, composição, temas sobre funcionalismo e "elementos de arquitetura", que Howard Robertson publica o livro "The Principles of Architectural Composition".

Ele acreditava que composição era um tema a ser debatido e uma crítica deveria ser feita. Robertson, em seus "princípios de composição" (que também foram chamados por Colin Rowe de "denominadores comuns formais" ${ }^{3}$ do passado, presente e futuros monumentos) defende composição como o fator primeiro na arquitetura enquanto detalhes e ornamentos seriam secundários. No seu argumento, o projeto e o estilo do edifício eram independentes do volume compositivo do objeto arquitetônico.

Os elementos de arquitetura, compostos, criam uma relação de interferência estética entre eles através das regras ditadas pela composição. $O$ arquiteto possui a função de coordenar estes elementos a fim de criar uma "boa obra".

Neste raciocínio, ele segue considerando a oposição do funcional com o abstrato em uma exposição acerca de uma composição que considera a estética como efeito compositivo do edifício sem relação com seu uso ou estrutura e lida tanto com elementos de proposição (elementos formais no edifício), métodos de construção e todas outras questões que podem estar relacionadas com o que ele chama de "design funcional" 4 .

A teoria funcional dirigia o pensamento da arquitetura ao enfoque da tecnologia de modo a prover o edifício com a tecnologia apropriada para a época apropriada.

Já na teoria abstrata, formalista, os edifícios deveriam ser julgados por suas qualidades de cor, massa e linhas, opondo-se à qualificação estilística. Desse modo uma análise da arquitetura não se restringe aos estudos de estilo, mas à maneira como a arquitetura se compõe.

\footnotetext{
3 "formal common denominator", no original em inglês.

${ }^{4}$ PAI, 2002, p. 100.
} 
Robertson ainda afirma que apenas com a compreensão das leis de composição, i.e. a gramática do design, este design funcional poderia ser traduzido em criação arquitetônica. Já estão presentes nesse argumento traços da influência lingüística ao mencionar "gramática" e "tradução". Vemos tais argumentos nessa citação:

\begin{abstract}
"As necessidades práticas dos edifícios, sistemas de planos projetados para satisfazer as condições de 'programas' arquitetônicos específicos, assim como a expressão funcional da arquitetura, o modo como ela é manifestada nas características e status de um edifício, ou na disposição de parte de acordo com necessidades utilitaristas, não têm nada a ver com o tema presente, que é a linguagem da arquitetura" ${ }^{5}$. [grifo meu]
\end{abstract}

O que ele queria dizer era pensar o edifício como uma regra compositiva, que seria o primeiro passo para criar uma arquitetura em seu design funcional. A forma abstrata compositiva do volume do edifício seria lei para os passos seguintes. Em sua catalogação mostrada no livro "The Principles of Architectural Composition" não mostrava elementos arquitetônicos como portas, decoros, mas como tipos arquitetônicos.

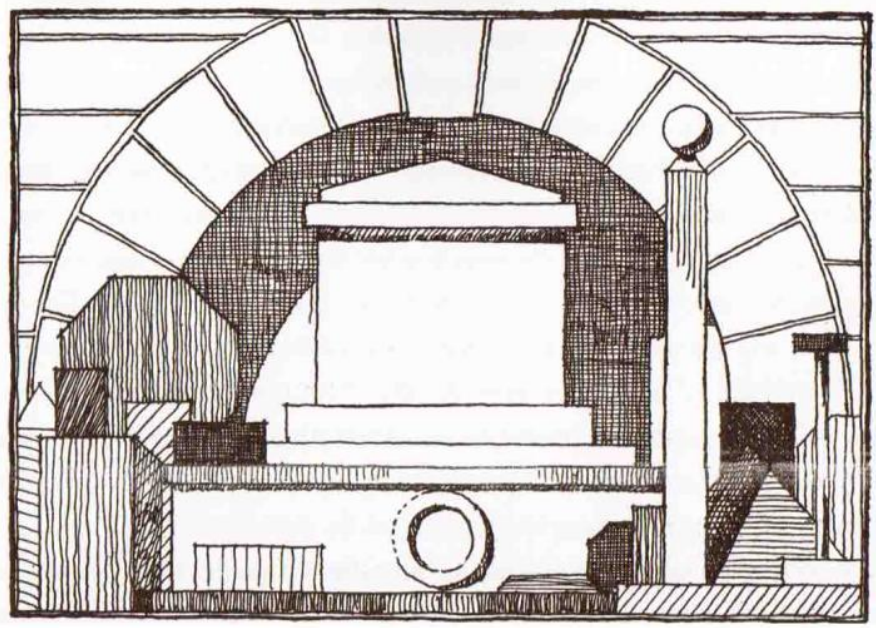

Figura 1.1 Composição de Modelos Geométricos e Formas Simples. Howard Robertson, 1924.

De acordo com Hyungmin, durante os anos 20 e início dos anos 30 "a inquietação que havia se criado entre composição e planejamento, forma e função,

\footnotetext{
5 "The practical requirements of buildings, systems of planning designed to satisfy the conditions of particular architectural 'programmes', even the expressional function of architecture, so far, as this is manifested in the character and status of a building, or in the disposition of parts in accordance with utilitarian needs, has nothing to do with the present theme, which is the language of architecture". ROBERTSON (1923, apud PAI, 2002, p.100).
} 
começou a emergir em vários debates arquitetônicos" "6. A discussão se dava, sobretudo, sob o argumento dos "tradicionalistas" de que não deveriam acontecer repetições da história, mas que ela era um ponto de partida para projetos futuros. Já os "modernistas" afirmavam que deveria existir um rompimento com a história e seus projetos deveriam partir de algo novo que não tivesse qualquer referência com o passado.

Um debate da época era a defesa por uma posição de abstracionismo onde os edifícios deveriam ser julgados não pelo estilo, mas pelas suas qualidades formais: massa, linha e cor. A questão importante era como o edifício, seja ele Gótico, Oriental ou Clássico, formava sua "gramática de design".

O outro ponto nesta discussão entre os abstracionistas (gramática da arquitetura) e os funcionalistas (que seguiam a teoria funcional mencionada anteriormente) era que esses defendiam a idéia da absorção da nova tecnologia pela arquitetura moderna a fim de resolver os problemas complexos que apareceram nas instituições modernas.

\begin{abstract}
"O movimento moderno não se importa de forma alguma como se aparenta. Ele não se preocupa com os precedentes seguintes ou abandonados, nem está interessado com as novas regras de arte derivadas da máquina, nem se existem quaisquer regras... O artista ou crítico que lhe diz que tempo, ritmo, simetria dinâmica, discordância de cores, movimento, padrão ou a inspiração da máquina são qualidades básicas da nova arte, está divulgando as mesmas hipocrisias que a nova arte está tentando superar. Estas novas qualidades podem ocorrer na arte moderna, mas elas são acidentais e não essenciais a ela. Moderno envolve uma tentativa sincera em ser honesto" 7 .
\end{abstract}

Nesta citação de Raymond Hood e Ely Jacques Kahn, percebemos que esse "honesto" de que tratam é manter a arquitetura imersa nas estruturas comerciais e tecnológicas da época e, deste modo, não havia necessidade de efetivar o discurso de forma x representação.

\footnotetext{
6 "the schism that had formed between composition and planning, form and function, began to surface in the many architectural debates of the period". PAl, 2002, p. 106.

7 "The modern movement does not concern itself with looks at all. It does not care whether we abandon or follow precedent, nor is it interested as to whether the new rules of art are derived from machine, nor even whether there are to be any rules at all.... The artist or critic who tells you that time, rhythm, dynamic symmetry, color discordance, motion, pattern, or the inspiration of the machine are the basis qualities of the new art, is passing out the same old hypocrisies that the new art is trying to overcome. These qualities may occur in modern art, but they are incidental and not essential to it. Modern involves a sincere attempt to be honest". HOOD (1929, apud PAI, 2002, p 108-109).
} 
Durante estas discussões sobre composição/abstração, função/forma e tecnologia no início dos anos 20 , inicia-se uma fragmentação da disciplina de arquitetura, uma transição fundamental onde um sistema antes dominante "estava se desintegrando em suas próprias sombras fragmentadas" ${ }^{8}$. Fiske Kimball menciona em seu livro "American Architeture" que estes fatos criaram uma divisão da arquitetura entre dois pólos do modernismo: um funcional, científico e objetivo, e outro formal, estético e abstrato ${ }^{9}$.

$\mathrm{Na}$ metade dos anos 20, durante as discussões antes apresentadas, surgia como tema o novo arranha-céu que deveria ser "a expressão da estrutura" e que mostrava a supremacia desta sobre a forma. A composição do edifício se mantinha a mesma, linhas verticais e de grandes dimensões, mas não regrada pelo desejo do arquiteto ou do estilo, mas pela legislação urbana. Logo a variável de classificação "composição" estaria superada.

A dúvida que permeava a disciplina era expressa por Henry-Russel Hitchcock e Philip Johnson ao afirmarem que a rejeição da disciplina por estilos passados cria um vácuo que expõe a arquitetura a qualquer resultado possível, ocasionando a perda de uma disciplina de arquitetura em comum, mas ao mesmo tempo não poderia ser aceito o ecletismo teórico dos tradicionalistas e os modernistas. Para Hitchcock, o funcionalismo não criava uma teoria sólida na qual a disciplina se fundava, uma vez que efetuar um projeto através de escolhas técnicas criaria um "complexo desconexo" e não seria inteligente, ordenado e nem mesmo poderia ser chamado de arquitetura. Para ele, a consciência do designer (ou projetista) cria ordenação e é um processo inteligente que, neste caso, deveria ser considerado arquitetura. $^{10}$

Deste modo, no final dos anos 20 ficou claro que a autonomia e a unidade disciplinar do profissionalismo acadêmico não poderiam mais ser mantidas. $O$ surgimento do pensamento funcionalista havia criado as bases para a separação entre forma e função, e deste modo, promovendo na arquitetura a transição de um sistema anteriormente homogêneo em direção a uma fragmentação.

\footnotetext{
${ }^{8}$ PAI, 2002, p. 163.

${ }^{9}$ KIMBALL (1928, apud PAI, 2002, p. 110).

${ }^{10}$ HITCHCOCK (1927, apud PAI 2002, p. 114).
} 
Durante este ambiente desconexo ocorria um estudo que forneceu estrutura para o processo de pensamento do taylorismo ${ }^{11}$ cujo objetivo era a geração de um conjunto de metodologias de análise sob o nome de "administração científica" ou "scientific management" profundamente calcadas sob a classificação, tabulação e redução do conhecimento empírico disperso em regras, leis e fórmulas a fim de promover a eficientização de processos. ${ }^{12}$

Diagramas funcionais, de análise de ações humanas, aparecem inicialmente na administração científica e posteriormente são transferidos para o campo da arquitetura. Mas, neste sentido, não é correto afirmar que o diagrama nasça na "administração científica" como sendo uma invenção deste campo, uma vez que, como mencionamos anteriormente, a definição de "origem" do diagrama é uma questão perniciosa já que o conceito não é apenas imagético, mas, como mostraremos posteriormente ${ }^{13}$, pode ser pensado também no campo cognitivo. $O$ diagrama que aparece neste momento faz parte de um discurso funcionalista e se mostrou como mecanismo representativo de relações observadas nos processos. Contudo, Hyungmin alerta que a relação entre a arquitetura e a administração científica não é um novo campo de pesquisas uma vez que existem muitas publicações na Europa, sobretudo na Alemanha sob este tema. ${ }^{14}$

Tais pressupostos possuem um ponto em comum que é observado nos diagramas deste conceito: a idéia de autoridade do pensamento.

Ele é baseado no pensamento de que um saber científico possui autoridade e pode ser separado da prática, um raciocínio a priori, servindo como mecanismo de controle do fazer. Nessa relação entre concepção e execução, o diagrama emerge como um mecanismo necessário para o sujeito controlar seu objeto de conhecimento.

"baseado na autoridade do pensamento científico, o gerenciamento científico assumiu que o conhecimento poderia ser separado da prática e,

\footnotetext{
11 Teoria publicada por Frederic Winslow Taylor (1856-1915) no ano de 1911 sobre estudos de eficiência no trabalho fabril.

12 PAl, 2002, p. 175.

${ }_{14}^{13}$ Segundo capítulo dessa dissertação.

${ }^{14}$ Durante os anos 30, muitos teóricos da gestalt fugiram da Alemanha e se estabeleceram nos Estados Unidos tal como Kurt Lewin, Jacob Moreno e Fritz Heider, que influenciaram a psicologia social (Jacob Moreno) no desenvolvimento do uso de diagramas, sociogramas, para mapeamento e formalização das relações sociais. Cf. PAI, 2002, p. 342.
} 
deste modo, funcionar como meio de controle da prática. (...) o diagrama emerge como um mecanismo necessário para o sujeito controlar seu objeto de conhecimento. (...) Sua genialidade reside na invenção de um código discursivo que organiza a realidade em direção ao que pode ser tanto útil como visível. Ele é o emblema da crise moderna de representação, uma condição histórica na qual 'o conhecimento científico de objetos é nada além do resultado de manipulação de signos, e que sua 'verdade' [a dos objetos] é meramente a sua utilidade para o melhoramento da vida dos homens". ${ }^{15}$

Em toda instrumentalidade profetizada da modernidade estava embutido o caráter da busca pela verdade. Esta busca estava inserida dentro da administração científica, assim como em outras ciências, como a semiótica, sob um pensamento positivista em prol da aplicação de sistemas produtivos dentro da sociedade através de analogias com os sistemas mecânicos. A ciência de controle de produção tinha como meta criar um ritmo na manufatura. Desta forma se anuncia a metáfora do "homem como máquina".

\begin{abstract}
"'Se eliminarmos de nossos corações e mentes todos os conceitos mortos a propósito das casas e examinarmos a questão a partir de um ponto de vista crítico e objetivo, chegaremos à 'Máquina de Morar', a casa de produção em série, saudável (também moralmente) e bela como são as ferramentas e os instrumentos de trabalho que acompanham nossa existência"'. ${ }^{16}$
\end{abstract}

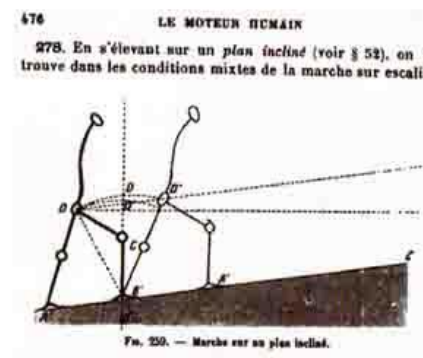

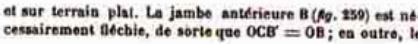

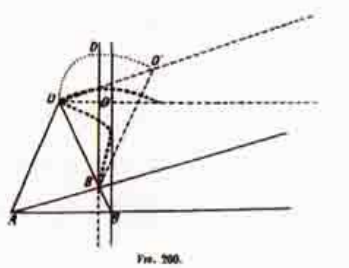

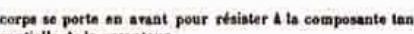
gentielle de la pesanteur.
Figura 1.2 Análise do movimento. Retirado de Jules Amar. Le moteur humain, 1914.

Assim acontece a descrição dos movimentos dos corpos, do fluxo e do uso de uma residência a fim de uma maximização da eficiência e departamentalização do

\footnotetext{
${ }^{15}$ Ibid., p. $163-164$.

${ }^{16}$ CORBUSIER (1923, apud FRAMPTON, 2008, p. 183).
} 
trabalho ao executar ações simples e claras. O corpo do homem pensado como um complexo de engenharia, motor e máquina humanos.

De acordo com Hyungmin, durante a década de 1910, o casal Frank e Lillian Gilberth criou alguns dos mais meticulosos métodos de medição e regulação do corpo promovendo uma concepção de função e padronalização através do princípio que a função não é classificada como são executadas pelos homens, mas são os homens que são classificados de acordo com a execução das funções. Daí surge a padronalização, com a qual o progresso e a evolução se tornariam mais rápidos ${ }^{17}$.

Seguindo este raciocínio, o corpo humano se transformava em um conjunto de mecanismos como uma simples unidade funcional o que permitiu o desenvolvimento de diagramas funcionais como uma ferramenta de gerência de operações.

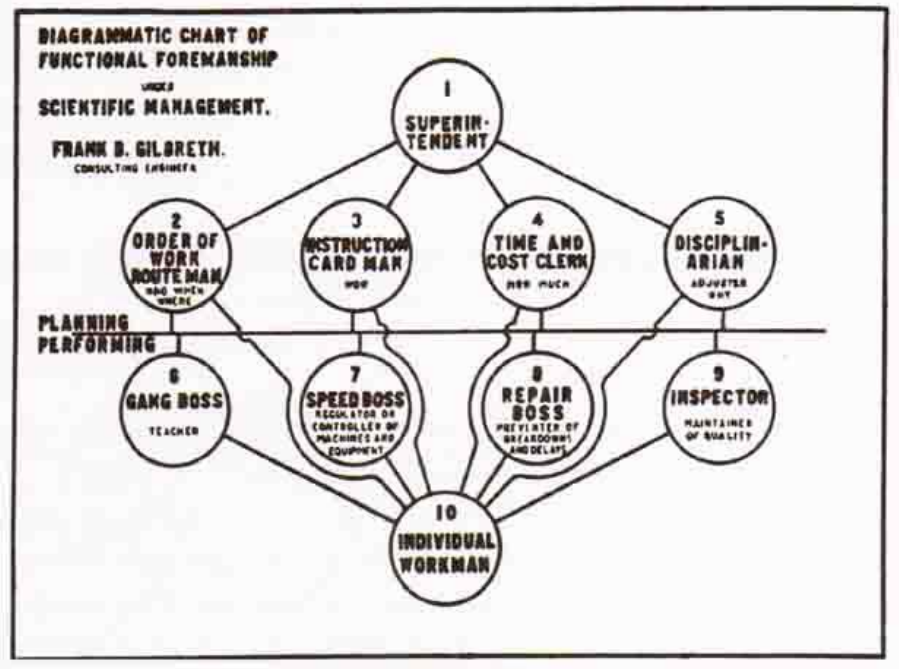

Figura 1.3 Mapa de supervisão funcional:

Gerenciamento Científico

Frank e Lillian Gilbreth, 1917

Como estes diagramas eram estáticos, uma abstração, era necessário um sistema de gerenciamento para promovê-lo na fábrica. Tal sistema era composto por cartões de ponto, cronogramas, regras institucionais e qualquer outro mecanismo para exercer o controle dentro desta idéia de produção mecânica.

Um dos estudos feitos pelos Gilbreths foi derivado do uso de fotografias que analisavam a postura e os movimentos do corpo ao executar uma dada tarefa. $\mathrm{Na}$ pesquisa usando o princípio de representação ciclográfica, poderia ser visto o diagrama de rotina que, de acordo com o casal, se baseia em dois conceitos:

${ }^{17}$ GILBRETH (1914, apud PAI, 2002, p. 165). 
planejamento do movimento de materiais e equipamentos e acompanhamento da performance do trabalhador em uma tarefa. Em ambos os casos o movimento do corpo era registrado e produziam-se imagens a serem analisadas por um engenheiro que identificaria e prescreveria o melhor movimento. Deste modo, tais diagramas se tornavam uma ferramenta disciplinar e os funcionários eram treinados a executarem o processo da 'melhor maneira' possível.

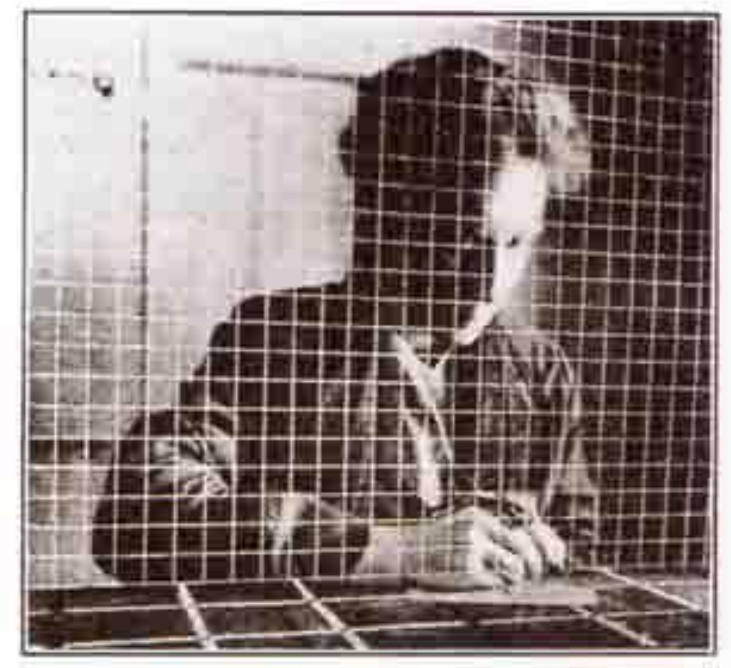

Figura 1.4 Registro do movimento através do método ciclográfico - Frank e Lillian Gilbreth, 1917

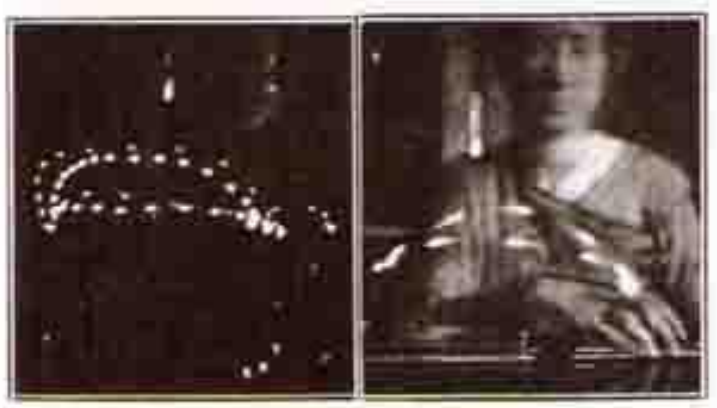

De acordo com Hyungmin, a solidificação do diagrama em arquitetura acontece nos anos 30 através dos anúncios de mobiliário e é devida principalmente pela discussão e repercussão das publicações de Christine Frederick. Em seu livro The New Housekeeping, que foi amplamente criticado em movimentos feministas durante a República de Weimar, havia vários diagramas funcionais com objetivo de mostrar a dinâmica de uma residência no dia-a-dia. Nos diagramas expostos por Christine Frederick existiam duas funções na cozinha - a rotina de preparação e a de limpeza. 

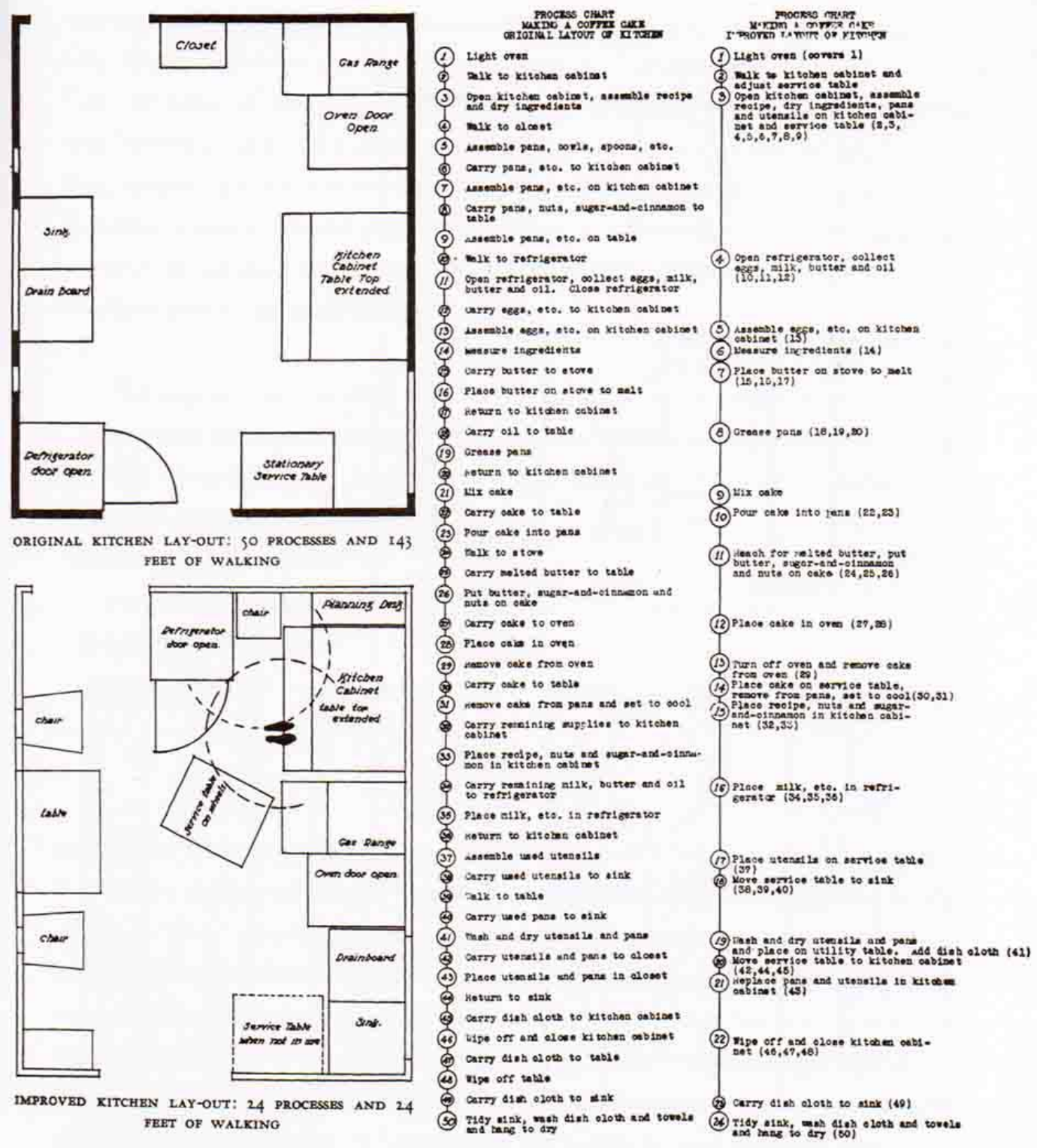

Figura 1.5 Procedimentos necessários para fazer um bolo.

Já no século XX, mais precisamente em março de 1929, um número da revista Architectural Record apresentava imagens com estudos sobre tipos de apartamentos de Henry Wright além de diagramas do arquiteto Alexander Klein sob o título de "llustrações de estudos de eficiência alemães". 
THE ARCHITECTURAL RECORD

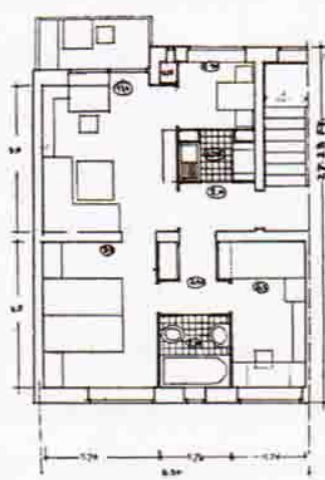

Fig. (a)

Area 435 sq. ft: 3 bed 145 sq. ft. per bed

$142 \mathrm{sq}$. it. per bed

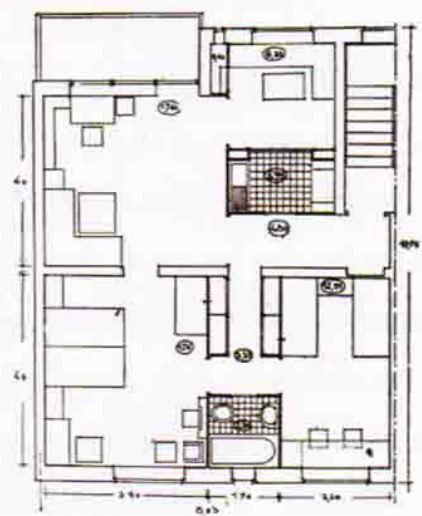

Fig. (c)

Area $752 \mathrm{sq}$. ft.; 4.5 beds $167 \mathrm{sq}$. ft. per bed

Planning. The three plans above were competition in Germany for House Plansig. The

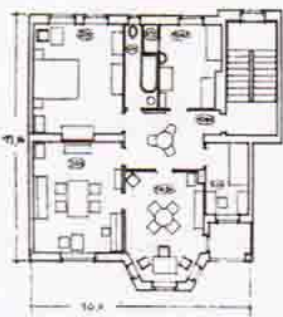

Fig. (d)

Ground floor plans as originally laid out

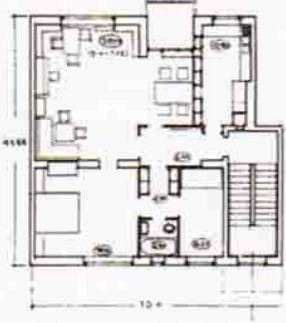

Fig. (e)

Designer's study of a ground floor plan of same dimension as Fig. (d). Staircase moved to avoid through-passage on ground floor

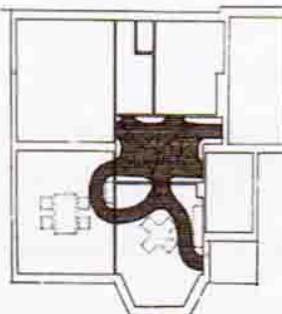

Fig. (h)

Shaded section indicates wasted space in arrange ment Fig. (d). Seating in living, dining room an hall is inefficient

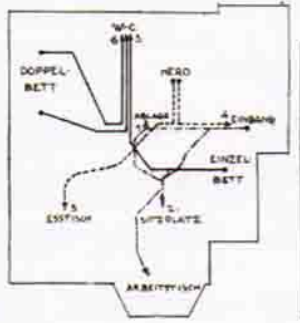

Fig. (f)

Diagram showing lines of traf fic direction in plan Fig. (d) For daily activities cross-tra fic is necessary

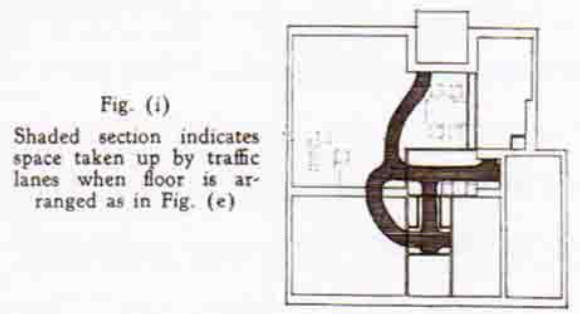

From DIE BAUGILDE, November 29, 1927

ILLUSTRATIONS OF GERMAN EFFICIENCY STUDIES

Figura 1.6 Estudos de Eficiência Alemães

Podemos perceber, tanto nos diagramas de Henry Wright como de Cristine Frederick o espírito racional do Taylorismo, na redução do processo de trabalho para máxima eficiência: "minimize waste motion and unnecessary steps".

No ano de 36, na publicação Architectural Forum,(sem diagramas e no ano de 1940 com diagramas) George Howe publica plantas com diagramas de uso dos espaços e sob o discurso que estes gráficos usavam eixos curvilíneos ao contrário 
de retangulares e "teóricos" (no sentido de não-funcionais, utópicos) que foram utilizados por outros no passado.

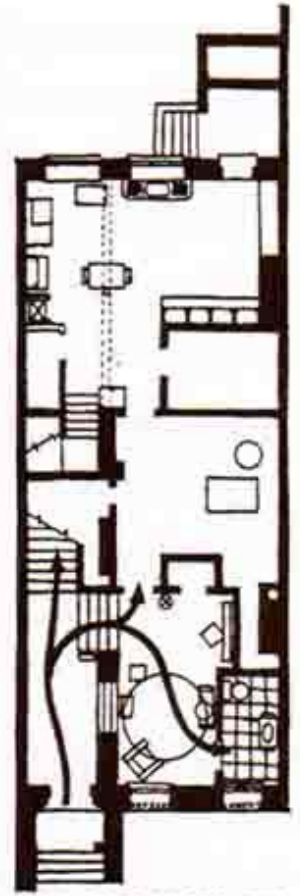

BASEMENT

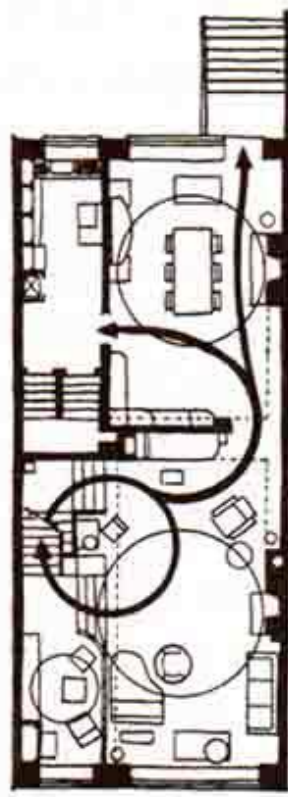

FIRST FLOOR
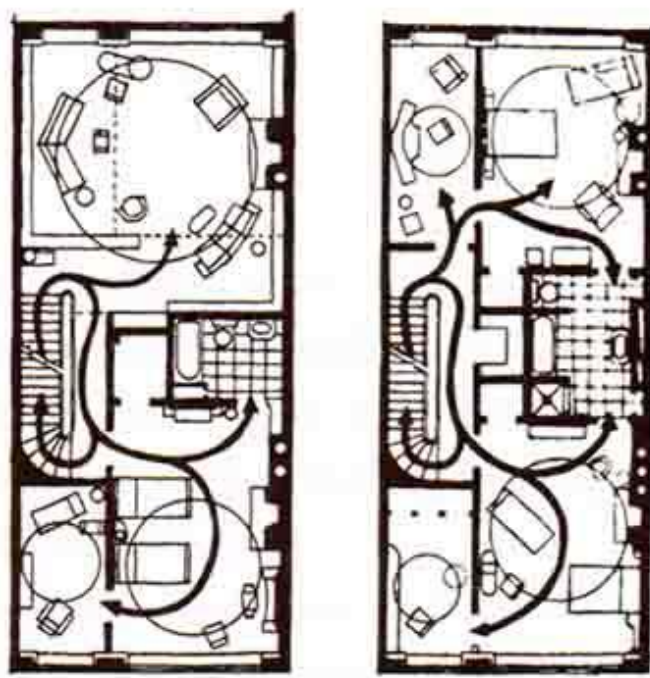

SECOND FLOOR

Figura 1.7 Projeto de Residência. George Howe, 1936.

Porém, estes diagramas não eram um fundamento generativo do projeto $\mathrm{e}$ sim, diagramas de circulação embutidos em um discurso arquitetônico ${ }^{18}$. Eles eram mais que diagramas de eficientização da rotina como os que repercutiam no ambiente da época. O diagrama como ferramenta disciplinar nas fábricas era um meio de promover o movimento ideal enquanto que os usados no contexto arquitetônico de estudo do espaço direcionavam para um estudo de espaços ideais.

Neste sentido, de estudo espacial, dinâmica da casa e do edifício, Ernest Irving Freese, arquiteto de Los Angeles, em 1934 criou o que foi chamado de "Homem padrão" ${ }^{19}$ na revista American Architect.

\footnotetext{
18 PAl, 2002, p. 184.

19 "Average man"
} 

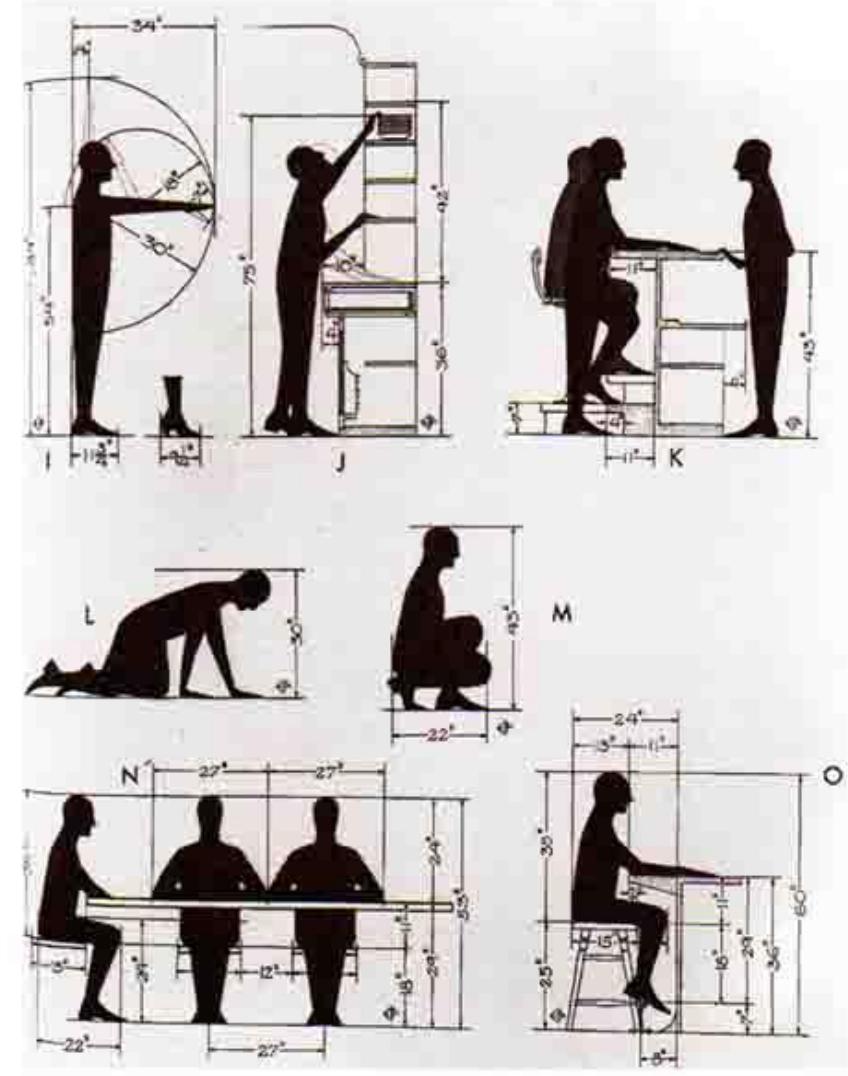

Figura 1.8 Geometria da

Figura Humana.

Ernest I. Freese, 1934

Hyungmin afirma que o primeiro artigo sobre dados antropométricos aparece em 1932 na revista Architectural Record no artigo de Lawrence Kocher e Albert Frey, mas sabemos que essa idéia de proporção humana refletida no espaço tem fundamentação antiga, como por exemplo, o "homem vitruviano", o que corrobora a afirmação do capítulo de que uma origem do diagrama arquitetônico é tão antiga quanto à própria arquitetura.

John Hancock Callender, que trabalhou durante os anos 30 na Fundação John B. Peirce responsável por estudos sobre dinâmicas domésticas, criou um tipo de teoria funcionalista de projeto que seguia o argumento de que a casa deveria ser planejada para se adequar em torno das atividades da família do mesmo modo que um alfaiate ajusta uma vestimenta em torno do corpo humano. ${ }^{20}$

Estudos seguintes foram tomados por Jane Callaghan e Catherine Palmer, sobretudo nos livros "Headroom above the Slepping Surface (fig. 9)" e "Measuring Space and Motion" de 1943.

${ }^{20}$ PAI, 2002, p. 191. 


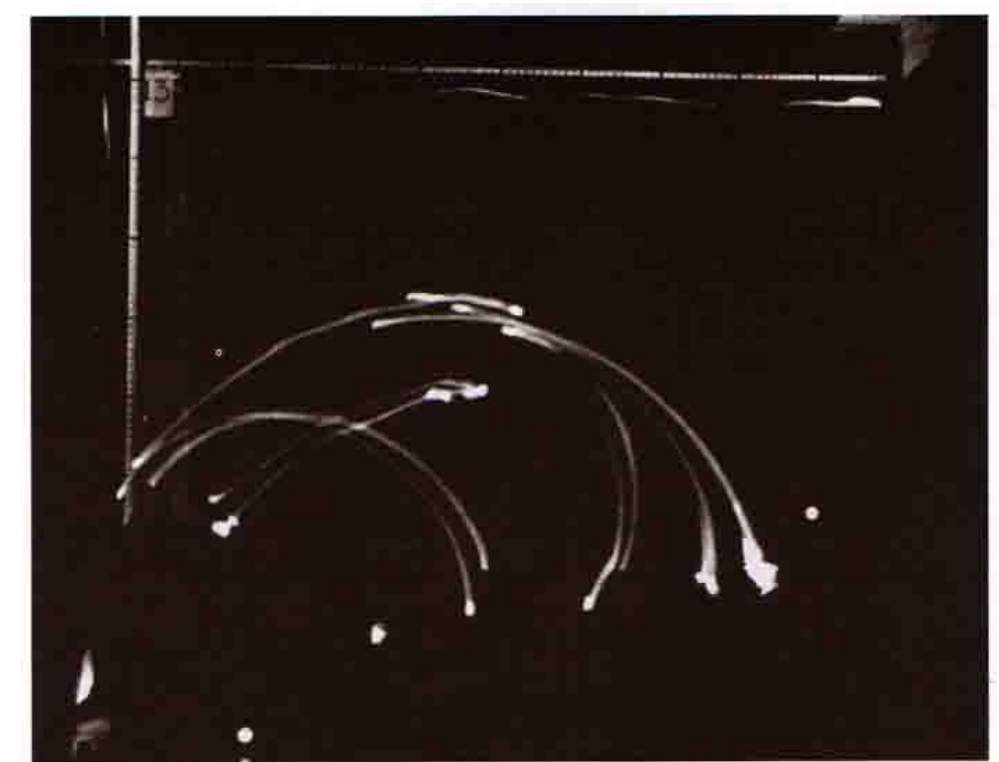

Figura 1.9 Mapeamento do movimento ao deitar. Análise da altura livre

A diferença destes estudos com os dos Gilbreths era que o do casal analisava o movimento a fim de ser adestrado e repetido continuamente ao passo que o de Callaghan e Palmer é destinado para análise da situação do corpo no espaço a fim de definir uma composição do mobiliário que fosse mais eficiente ao uso sob determinada função.

À medida que o diagrama funcional começou a tomar a arquitetura, e ainda calcado na discussão sobre forma-função, foi percebido o surgimento de um novo foco: o objeto arquitetônico metafórico. No uso de um diagrama para análise de um sistema de ventilação na casa criava o entendimento de que a casa era uma "máquina de respiração".

Como menciona Hyungmin, quando John Hancock Callender discutia os projetos de escolas, ele afirmava que elas deviam "funcionar como uma peça-chave no processo de educação". ${ }^{21}$

De acordo com Hyungmin, é no ano de 1937 que uma das exposições mais reveladoras do diagrama moderno acontece no artigo de Paul Nelson " $A$ Method of Procedure in Architectural Design" publicado na revista Architectural Record de

21 "function as a working part of the process of education". CALLENDER (1933, apud PAI 2002, p. 195). 
$1937^{22}$. Neste artigo Paul Nelson afirma que durante anos ele desenvolveu um método de aproximação de problemas arquitetônicos ${ }^{23}$ que consiste em três estágios: No primeiro é feita uma análise não arquitetônica - uma "abstração em termos de vida"; enquanto o segundo estágio é uma segunda análise arquitetônica, uma abstração da etapa anterior em termos espaciais, e, finalmente, o terceiro estágio, a síntese arquitetônica que, na verdade, é a "concretização em termos de arquitetura" $^{24}$.

Para ele, o primeiro estágio seria uma descoberta da metafísica do sujeito, da casa, e de tudo mais relevante naquele projeto. Seria o mais fundamental de modo a fornecer uma nova e vital arquitetura. Seria uma fase onde questões psicológicas e a dinâmica da vida na casa seriam analisadas, abstraindo as funções de modo a alimentar um segundo processo que seria de formalização destas variáveis para, enfim, serem conformadas no edifício construído, na terceira etapa. Paul Nelson ainda declara que tal processo é dialético e que a realidade cria a idéia, ao contrário de uma idéia pré-concebida ou até mesmo uma fórmula ${ }^{25}$.

Ou seja, percebe-se a tentativa de criar uma arquitetura dedicada a resolução de problemas de projeto e não vinculada a desejos de artistas. O uso de diagramas funcionais para estudo da casa, como assimilação de novos pensamentos para fundar as novas arquiteturas. O diagrama ainda parece surgir da insatisfação e discussão moderna entre os tradicionalistas e os modernistas, como mostrado anteriormente.

\footnotetext{
${ }^{22}$ Architectural Record, v. 81, jun / 1937, p. 53-57.

23 "Approach for architectural problems".

${ }^{24}$ Op. cit., p. 53.

${ }^{25}$ Architectural Record, v. 81, jun / 1937, p. 53.
} 


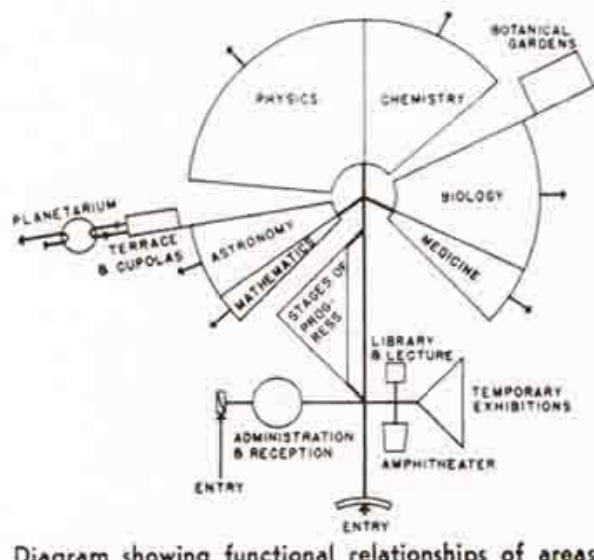

Diagram showing functional relationships of areas

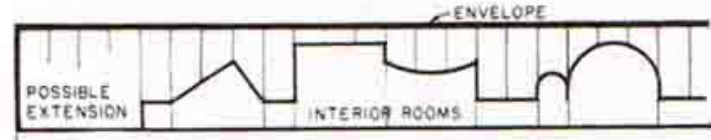

- Limits of site

Envelope

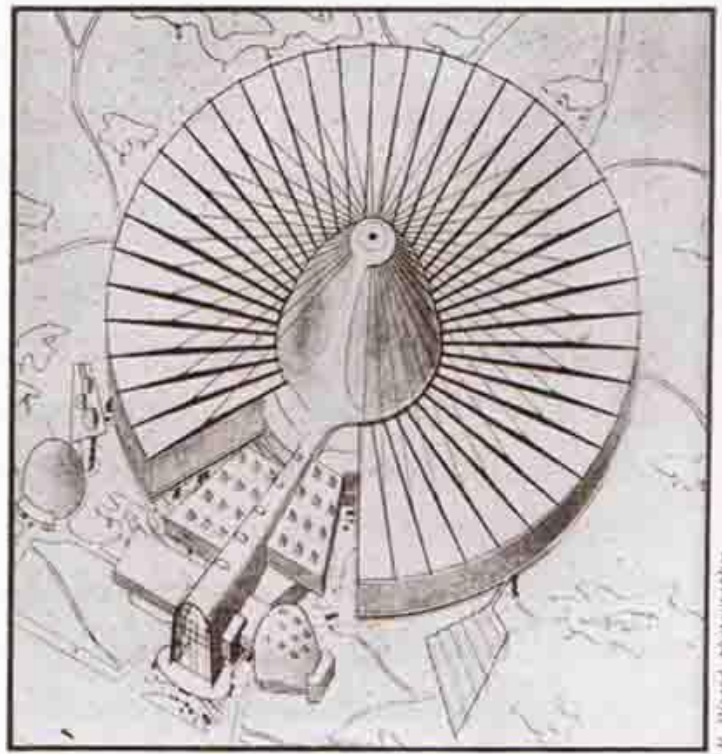

Perspective view from entrance side

Figura 1.10 Projeto para o Museu da Ciência. Paul Nelson, 1937.

Nos estudos de Nelson, na Revista Architectural Record de 1937, assim como na figura 10 o que acontece é o desenho do diagrama antes do desenho axonométrico representativo do projeto. Um diagrama composto por elementos organizados por suas relações funcionais ao invés de relações formais. Deste modo, a tradução do diagrama em edifício arquitetônico, como a figura 10, seria a criação de um edifício não pré-julgado por tipologias existentes, mas nascido de "funções espirituais e materiais da vida em questão."

(...)contrário à noção que o diagrama e planta são fases distintas no processo de design, existe uma continuidade analógica constante entre as linhas do diagrama e aquelas da planta". ${ }^{26}$

\footnotetext{
26 " [...] contrary to the notion that the diagram and the plan were distinct phases of the design process, there was a constant analogical continuity between the lines of the diagram and those of the plan". PAI, 2002, p. 248.
} 


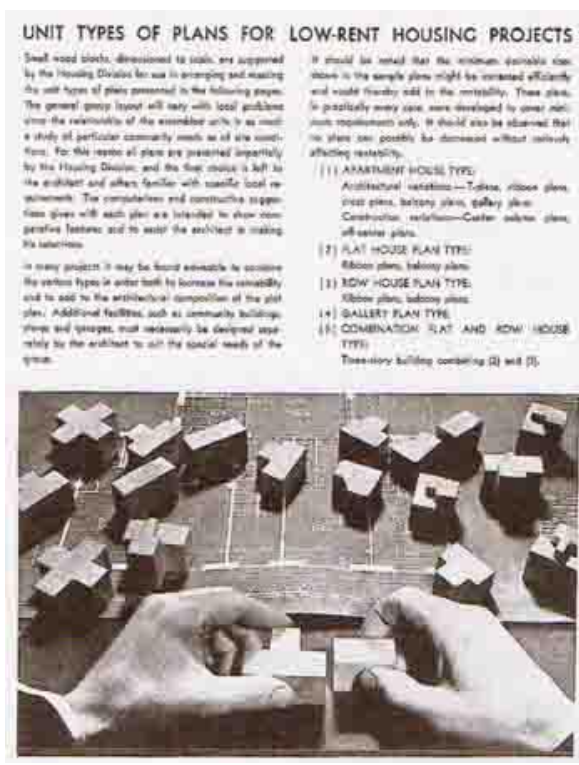

AYBEAGE ROOY STZES OF HOUSES 1 1TSPBOTE

by U. S, Dept. of conizer

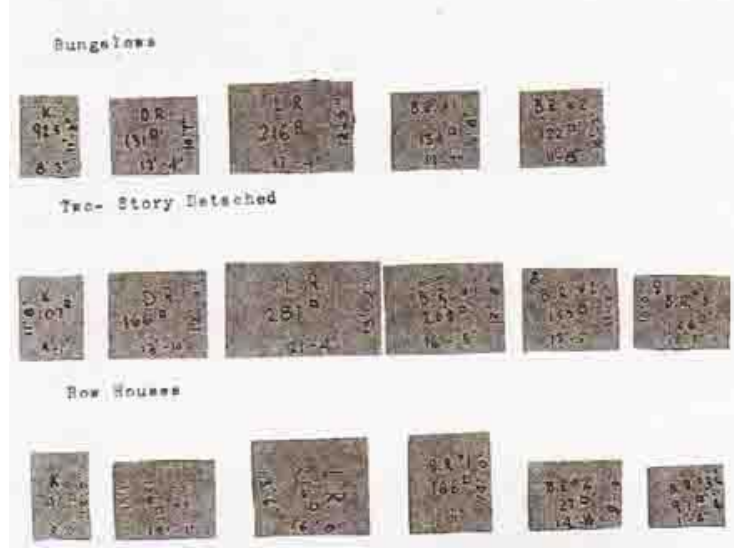

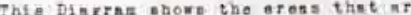

deezed osentssis by thoueand of

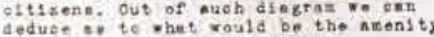

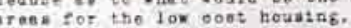

Figura 1.11 Metodologia de projeto a partir da composição de blocos
Figura 1.12 Unidades habitacionais funcionais. Cada quadrado representa um modelo de casa, com suas dimensões registradas.

$\mathrm{Na}$ arquitetura moderna a forma se torna diagrama e o diagrama se torna forma ${ }^{27}$. O processo anterior era desenvolvido através de uma racionalização da arquitetura que gera suas formas complexas a partir de sólidos platônicos enquanto, num instante seguinte, os próprios estudos tayloristas geravam suas formas. O que transita neste processo é o poder de síntese e a capacidade de um diagrama

${ }^{27} \mathrm{PAl}, 2002$, p. 252. 
traduzir o verbal para o não-verbal. Em um dado momento o processo sintetiza as formas complexas em formas simples e em outro sintetiza relações complexas em formas.

Havia um hiato na relação fala-obra que o diagrama era chamado a preencher. Ele era um dispositivo disciplinar, acabava de prover a disciplina de uma ferramenta com a promessa de um potencial projetivo que nos mecanismos cognitivos tradicionais não eram suficientes.

No pós-guerra, a arquitetura estava se motivando à preocupação do programa como premissa projetual. Para Summerson se o arquiteto não aceitasse o programa como fonte de unidade, ele teria duas alternativas: ou procurava por uma linguagem da forma arquitetônica, ou seja, uma gramática ou ele se apoiava em seus subjetivos impulsos criativos de expressão ${ }^{28}$.

\begin{abstract}
"Os problemas políticos, econômicos e sociais enfrentados pelos países capitalistas avançados na esteira da Segunda Guerra Mundial eram tão amplos quanto graves. A paz e a prosperidade internacionais tinham de ser construídas de alguma maneira a partir de algum programa que atendesse às aspirações de povos que tinham dado maciçamente suas vidas e energias numa luta geralmente descrita (e justificada) como luta por um mundo mais seguro, por um mundo melhor, por um futuro melhor. Isso por certo não significava o retorno às condições pré-guerra de recessão e desemprego, de marchas contra a fome e locais de distribuição de sopa, de habitações deterioradas e de penúria, nem ao descontentamento social e à instabilidade política que essas condições tão facilmente propiciavam. Para se manter democráticas e capitalistas, as políticas do pós-guerra tinham de tratar de questões de pleno emprego, de habitação decente, de previdência social, do bem-estar e das amplas oportunidades de construção de um futuro melhor" 29 .
\end{abstract}

Deste modo, em toda parte aconteciam mobilizações para a racionalização da produção de casas, escolas, hospitais e renovação urbana através de um desenvolvimento planejado e legislação urbana. Le Corbusier, CIAM, Mies van der Rohe e Frank Lloyd Wright tiveram ampla aceitação pela força teórica que embasava o que os engenheiros, políticos e construtores da época desejavam realizar com intuito de realização política, social e econômica.

Mas é no pós-modernismo, em arquitetura, que o conceito de diagrama ganha aparência. A assimilação de conceitos lingüísticos, e o entendimento da gramática

\footnotetext{
${ }^{28}$ PAI, 2002, p. 282.

${ }^{29}$ HARVEY, 1996, p. 71.
} 
da arquitetura permitem a geração de um conjunto de experiências que instauram um ponto de inflexão no pensamento de projeto em arquitetura.

Mario Gandelsonas explica em seu texto "Linguistics in Architecture" que nos durante a década de 60 e começo dos anos 70, a lingüística atuou de modo fundamental nas ciências sociais como uma 'disciplina piloto' e foi amplamente teorizada nas produções antropológicas, estéticas e filosóficas. 


\title{
1.1 - A gênese do diagrama pós-moderno
}

Charles Jencks avisara que o fim do modernismo foi no dia 15 de julho de 1972 às 15h 32m, na demolição do conjunto habitacional Pruitt-Igoe sob o motivo de ter sido considerado inabitável para as pessoas de baixa renda que o habitavam. "Aprendendo com Las Vegas" de Venturi e as possibilidades apresentadas por Denise Scott Brown e Steven Izenour apareceram como alternativa para o já então falecido movimento moderno e, a partir de então, pós-moderno. $\mathrm{O}$ ideal gerado era que os arquitetos deveriam ter um comportamento fenomenológico entendendo a cidade não mais através de idéias abstratas e doutrinárias, mas em estudos do ambiente da cidade, construindo "para as pessoas e não para o Homem" ${ }^{30}$.

\begin{abstract}
"Os planejadores 'modernistas' de cidades, por exemplo, tendem de fato a buscar o 'domínio' da metrópole como 'totalidade' ao projetar deliberadamente uma 'forma fechada', enquanto os pós-modernistas costumavam ver o processo urbano como algo incontrolável e 'caótico', no qual a 'anarquia' e o 'acaso' podem 'jogar' em situações inteiramente 'abertas"” 31.
\end{abstract}

Enquanto os modernistas pressupunham a relação dualista - significado (a mensagem) e significante (o modo como era dito) - uma relação rígida entre o que era dito e como estava sendo falado, no pós-modernismo temos a interpretação de que este sistema se refazia a cada instante em novas combinações.

Mário Gandelsonas ${ }^{32}$ explica que durante os anos 60 e 70 acontece uma apreensão enorme da lingüística pela arquitetura, sobretudo pela apropriação que o conceito de estrutura toma da antropologia, estética e filosofia.

Esse momento é caracterizado por Sóla-Morales como passagem de um pensamento linear para um pensamento estrutural que se dá pela percepção de que a história não é um processo linear, ilimitado. O estruturalismo aparece como um

\footnotetext{
${ }^{30}$ HARVEY, 1996, p. 45.

31 Ibid., p. 49.

32 "Linguistics in Architecture ", revista Casabella fev/1973, p. 17-31
} 
método, um instrumento explicativo que se mescla às diversas ciências através da analogia com a linguagem verbal.

\begin{abstract}
"Um principio metodológico fundamental consiste em, uma vez reconhecido um sistema estrutural, o que devemos conhecer é sua mecânica interna, os protocolos que regem a economia de seus movimentos e as possibilidades que, de algum modo ele possuía desde o início, este sistema tem para revelar". ${ }^{33}$
\end{abstract}

Gandelsonas, em "From Structure to Subject: The Formation of an Architectural Language" cita Claude Levi-Strauss, ${ }^{34}$ elaborando uma crítica sobre a formação arquitetônica através de uma lingüística e expõe como é interpretado o uso da linguagem no pós-modernismo para se afastar de um "caos" moderno:

\begin{abstract}
"O estabelecimento de uma sociedade pode ser vista como o estabelecimento de ordem, através da qual convenções, ou mais especificamente, o estabelecimento de uma linguagem através de códigos simbólicos. Antes da ordem, antes da linguagem, existe um caos primitivo onde não existem regras sobre casamento, construção, alimentação; neste caos, que precede a sociedade, existe apenas um campo infinito de potencial para manipulação dos reinos individuais e coletivos do verbal ao sexual. A sistematização e institucionalização de regras neste domínios, o fazer as regras, envolve pelo menos uma repressão do caos, do amorfo, e a invenção de códigos sociais de uma 'linguagem' de relações de parentesco, uma 'linguagem' do mito, ou uma 'linguagem' que expressa a organização espacial de uma tribo. (...) Em arquitetura, dois momentos podem ser isolados na história onde a fundação de uma nova linguagem foi precedida por um tipo de sacrifício ritual. $O$ estabelecimento de uma linguagem clássica e prática teoricamente organizada no Renascimento implicou na morte do arquiteto-construtor medieval quem, na definição de Alberti, 'trabalhava com suas mãos', em detrimento de um novo tipo arquiteto racional que trabalhava 'com sua mente'. Similarmente, até o começo deste século, o estabelecimento da arquitetura moderna contra o ecletismo do século XIX, a fundação de uma arquitetura que 'não tinha nada o que fazer com os estilos', no termos de Le Corbusier, sacrificou uma variedade estilística por uma ampla visão de abstração". ${ }^{35}$
\end{abstract}

33 "Un principio metodológico fundamental consiste en que una vez reconocido un sistema estructural
lo que debe conocerse es su mecánica interna, los protocolos que rigen la economía de sus
movimientos y las posibilidades que este sistema, de alguna manera ya dado totalmente desde el
comienzo, tiene para desplegarse". SOLÀ-MORALES, 2003, p. 81 .
34 LEVI-STRAUSS, Claude. "L'analyse structurale en linguistique et en anthropologie " Publicado
originalmente no "Word Journal of the Linguistic Circle of New York", vol 1, no 2 , agosto de 1945, p 1-
21 .
35 "The establishment of society can be seen as the establishment of order through conventions, or
more specifically, the establishment of a language through symbolic codes. Before order, before
language, there exists a primal chaos where there exists a primal chaos where there are no rules for
marrying, building, eating; in this chaos, which precedes society, there is only an infinite field of
potential for manipulation of the individual and collective realms from the verbal to the sexual. The
systematization and institutionalization of rules in these domains, the making of rules, involves at once
a repression of chaos, of the amorphous, and an invention of social codes of a 'language' of kinship
relations, a 'language' of myth, or a 'language' which expresses the spatial organization of a tribe.
(...)In architecture, two moments can be isolated in history where the foundation of a new language
was preceded by a kind of ritual sacrifice. The establishment of a classical language and a theorically 
De acordo com Gandelsonas, nestas duas circunstâncias, a expectativa era de formar uma organização sistemática dos códigos da prática arquitetônica ${ }^{36}$, para definir um aparentemente finito e estável número de elementos ou formas dentro de um sistema de significância fechado. Dentro do classicismo observamos que tal gramática poderia ser definida, uma vez que os elementos componentes seguiam regras definidas pelo "estilo", mas a continuidade deste raciocínio no modernismo acabou por miná-lo.

\begin{abstract}
"A linguagem apareceu muito cedo no desenvolvimento da humanidade. Mas, mesmo levando em consideração a necessidade de documentos escritos para empreender um estudo científico, reconhecer-se-à que a escrita data de muito tempo e que fornece séries suficientemente longas para tornar possível a análise matemática. [...] Conhecidas a estrutura fonológica de uma língua qualquer $e$ as regras que presidem ao agrupamento das consoantes e vogais, uma máquina estabeleceria facilmente a lista de combinações de fonemas que formam as palavras de $n$ sílabas, existentes no vocabulário e de todas as outras combinações que são compatíveis com a estrutura da língua, tal como teria sido definida previamente. Uma máquina, recebendo as equações determinantes dos diversos tipos de estruturas conhecidas na fonologia, o repertório de sons que $o$ aparelho fonador do homem pode emitir e os menores limiares diferenciais entre estes sons, determinados previamente (...), poderia fornecer um quadro exaustivo de estruturas fonológicas de $n$ oposições $(n$ podendo ser tão grande quanto se quisesse). Assim, obter-se-ia uma espécie de quadro periódico das estruturas lingüísticas, comparável ao dos elementos, que a química moderna deve a Mendeleieff". ${ }^{37}$
\end{abstract}

Como menciona Joan Ockman ${ }^{38}$ no começo dos anos 60, com o fim do funcionalismo como ideologia mestre em arquitetura, acontece um interesse por parte dos arquitetos na semiologia representada como uma nova tentativa de busca por um sistema codificável de sentidos arquitetônicos. Neste âmbito semiológico temos Noam Chomsky, Umberto Eco e Roland Barthes.

Mas no ano de 1967, Barthes apresenta um colóquio no Instituto de História da Arquitetura da Universidade de Naples sob o título de "Semiologia e Urbanismo" onde afirma um discurso lingüístico para a cidade, uma vez que "espaço humano em

organized practice of architecture in the Renaissance implied the death of the medieval architectbuilder who, in Alberti's definition, 'worked with his hands', in favor of the new rational architect who worked 'with his mind'. Similarly, at the beginning of this century, the establishment of modern architecture against nineteenth century eclecticism, the foundation of an architecture which 'had nothing to do with the styles', in Le Corbusier's terms, sacrificed stylistic variety to a high vision of abstraction". OPPOSITIONS READER, 1998, p. 201.

${ }^{36} \mathrm{Tal}$ como cria Christopher Alexander em "Notes on the Synthesis of Form" (1964) e "A Pattern Language: Towns, Buildings, Construction" (1977).

${ }^{37}$ LEVI-STRAUSS, 1985, p. 73-74.

${ }^{38}$ OCKMAN, 1993, p. 412. 
geral (e não apenas espaço urbano) sempre tem sido um espaço significante "39" e "a cidade é um discurso, e este discurso é, na realidade, uma linguagem" ${ }^{40}$. Para ele, uma semiologia urbana consistiria em um processo de separação do texto urbano em unidades, separadas em classes, descobrir regras de combinação e transformação para estas unidades e modelos. ${ }^{41}$

Mas esta interpretação de linguagem urbana é aberta posteriormente para outro entendimento. Segundo Barthes, como o palácio imperial se situa no centro da cidade de Tóquio ele deveria ser o centro da cidade, mas esta força simbólica esperada não acontece. Esse centro simbólico não coincide com o centro observado na cidade. Sabemos que esta análise é mais complexa do que simples constatação, mas através deste apontamento Barthes desenvolve o raciocínio de uma ineficiência na leitura diática - signo que corresponde a significado estrito - para o contexto urbano.

\footnotetext{
"Começando por estas leituras [urbanas], desta reconstituição de uma linguagem ou de um código da cidade, nós podemos nos orientar através de sentidos de uma natureza mais científica: investigação de unidades, sintaxes, etc., mas sempre lembrando que nós nunca podemos tentar fixar e apresentar significados rígidos das unidades descobertas, porque historicamente estes significados são extremamente imprecisos, mutáveis e inadministráveis.

(...) nós precisamos entender a interação de signos, entender que toda cidade é uma estrutura, mas que nós nunca devemos tentar e nem esperar preencher esta estrutura" 42
}

Derivando de uma crítica à interpretação lingüística da arquitetura, como signo-significante, surge o desconstrutivismo/ desconstrucionismo ${ }^{43}$ ao entender que, assim como um escritor já tem, embutido em si, referências de outros textos, a vida cultural também é formada por uma série de textos em constante intersecção de modo a produzir 'novos' textos. Desta forma, a filosofia pós-moderna francesa nos coloca como consumidores e produtores de textos e sentidos - no campo

\footnotetext{
${ }^{39}$ BARTHES, in OKMAN, 1993, p. 413.

${ }^{40}$ lbid., p. 415.

${ }^{41}$ Ibid., loc. cit.

42 BARTHES, in OKMAN, 1993, p. 418.

${ }^{43}$ GUATELLI, Igor Guatelli: A Desconstrução em Arquitetura: 1960 ou 1990?. Dissertação de mestrado, FAU USP, São Paulo, 1998 e tese de doutorado "O(s) lugar(es) do Entre na Arquitetura Contemporânea", 2005, defende o uso do termo desconstrucionismo a deconstrutivismo no intuito de evitar o entendimento de que a desconstrução de Derrida tenha sido uma evolução do Construtivismo Russo.
} 
artístico surgem performances, happenings e artes colaborativas. Acontece a minimização do autor e a emancipação da participação popular.

Deste modo a narrativa contínua social que até o momento acontecia, é quebrada. Na filosofia, os acontecimentos de 1968 em Paris produziram um descontentamento que criticava a razão abstrata se pondo em conflito a "todo projeto que buscasse a emancipação humana universal pela mobilização das forças da tecnologia, da ciência e da razão" "44. Neste momento Foucault instruía a preferirmos o que é positivo e múltiplo, a diferença à uniformidade, o que é produtivo, nômade, ao contrário do sedentário.

O desconstrutivismo em arquitetura, de acordo com Harvey, é "em parte como reação ao modo pelo qual boa parte do movimento pós-moderno se tornou a corrente dominante e se gerou uma arquitetura popularizada" ${ }^{45}$, teatral e fictícia.

"Ele compartilha com o modernismo a preocupação de explorar a forma e o espaço puros, mas o faz de uma maneira que concebe o prédio não como um todo unificado, mas como 'textos'”. 46

Textos que, por não serem alinhados ou definidos, podem ser lidos de formas múltiplas. Harvey ainda afirma que o que coloca os representantes da arquitetura Pop e os desconstrutivistas sob o título de pós-modernos, é a tentativa de representar a condição do sujeito instável, "um mundo desgovernado sujeito a um sistema econômico, político e moral desorganizado". Porém os desconstrutivistas usam a fragmentação, o caos e a desordem para produzir uma ruptura no modo habitual de percepção da forma e espaço.

Neste sentido, estes arquitetos (Eisenman será um bom representante deste momento) percebem a necessidade de trazer à tona as dificuldades de comunicação, culturas, interesses, complexidades e diferenças existentes nessa sociedade através de uma arquitetura atenta para a compreensão e reformulação dos signos sociais e estéticos homogeneizados pelo modernismo.

A desconstrução em arquitetura aparece em um momento caótico onde o pós-moderno se permitia "ler e ser lido" através de uma aplicação direta e

\footnotetext{
${ }^{44}$ HARVEY, 1996, p. 47.

${ }^{45}$ HARVEY, 1996, p. 95.

${ }^{46}$ Ibid., p. 95.
} 
exacerbada, potencializando e orientando "leituras" na arquitetura. Apesar dessa confusão significativa que passava o arquiteto, houve uma independência de um cânone unívoco da disciplina e permitiu uma variabilidade do pensamento. A liberdade individual juntamente com a ideologia de gerar sistemas de arquitetura(s) promoveu o desenvolvimento do processo projetual singular de cada arquiteto.

Ao mesmo tempo acontece a percepção da inexistência de uma arquitetura completamente autônoma que passa a se relacionar na lingüística nos anos 50 e diretamente na filosofia nos anos $80 \mathrm{com}$ Derrida através de Eisenman e Tschumi. É nesse processo de relacionamento da profissão com outros saberes que se percebe uma derivação do conceito de diagrama, tanto no conceito analítico dos modernistas como nos diagramas estruturais desenvolvido pelos arquitetos pósmodernos tendo Peter Eisenman como exemplo significativo. 
[Análise do conceito de diagrama em

Charles S. Peirce] 


\section{CAPÍTULO 2 - O percurso do diagrama através da semiótica peirceana}

O estudo do diagrama, seja pela visão arquitetônica ou de qualquer outra ciência em que este conceito se desenvolve, tende a ser direcionado pelo caminho da semiótica, criado por Charles Sanders Peirce (1839-1914).

Peirce produziu uma série de anotações sobre a teoria sígnica, mas somente alguns anos após sua morte, a partir de 1931, que elas foram publicadas sob o nome de "Collected Papers"1.

A teoria semiótica peirceana é fundamentalmente uma teoria do conhecimento. Ela traz o conceito de $\operatorname{signo}^{2}$ como uma estrutura tripla, uma das principais características que a diferencia da semiologia saussureana.

Esta estrutura tripla é composta pelo conjunto signo, objeto e interpretante numa relação multiplicadora e infinita onde cada signo, estabelecido pelo entendimento de um interpretante sobre um objeto, se torna objeto de uma nova cadeia representativa. Dentro desta cadeia, o signo pode ser determinado de três modos principais através da interpretação do objeto pelo interpretante: o signo como ícone, índice ou símbolo. Santaella ${ }^{3}$ os define deste modo: qualidades ou similaridades (ícones); fatos ou conexões de fatos (índices); leis ou hábitos (símbolos).

De acordo com Jorge ${ }^{4}$, essa estrutura de representação pode ser esclarecida da seguinte forma:

O ícone como uma relação por semelhança, identidade em algum aspecto entre signo e objeto. Ambos compartilham certa qualidade que é signo do objeto, independente da existência dele ${ }^{5}$.

\footnotetext{
${ }^{1}$ Neste capítulo iremos usar a sigla CP para fazer referência a "Collected Papers" PEIRCE,1978. O primeiro número se refere ao volume citado e os algarismos seguintes ao número do parágrafo. Por exemplo: 4.325 - A passagem citada corresponderia ao volume 4, parágrafo 325.

2 "(...) qualquer coisa que, sendo determinada por um objeto, determina uma interpretação à determinação, através dele, pelo mesmo objeto" CP 4.531

${ }^{3}$ SANTAELLA, 1995, p. 121.

${ }^{4}$ JORGE, 1999. P 39-41
} 
Peirce nomeia tal relação como monádica, de primeiridade ${ }^{6}$.

Já o índice estabelece uma relação de Secundidade que necessita da existência do objeto para que o índice se estabeleça. Tanto o signo e o objeto devem existir como fatos ${ }^{7}$.

E o terceiro elemento, o símbolo, se estabelece pela relação de Terceiridade. O signo é estabelecido por uma convenção, ou como foi citado, uma lei, tal como mencionar que duas linhas que se cruzam perpendicularmente representam a religião cristã e a suástica, apesar de também ser uma cruz, simboliza uma ideologia anti-semita. Esta conexão entre o signo e o objeto é totalmente dependente (talvez em maior grau que o índice e o ícone) de seu interpretante, a "mente-que-usa-osímbolo", sem a qual essa conexão não existiria ${ }^{8}$.

A relação que iremos descrever com mais atenção é a de Secundidade, o signo como ícone, uma vez que dentro desta qualidade Peirce deriva a de hipoícone que tanto pode ser uma imagem, uma metáfora ou um diagrama ${ }^{9}$.

Vejamos um entendimento do conceito de diagrama segundo Peirce:

"um ícone das formas de relações na constituição de seu objeto" ${ }^{10}$.

Analisando a frase acima temos:

O diagrama é um ícone, ou seja, se estabelece como um signo de algo e possui características, qualidades vinculadas ao objeto real. Por ser um ícone de relações, ele é algo (um signo) que representa as relações, o modo como os elementos interagem entre si formalmente ou simbolicamente. Ao analisarmos a composição sintática de um objeto, estabelecemos uma análise estrutural, um mapeamento das partes deste objeto. Se uma pegada na areia é um índice da existência de alguém, analisar o formato da mesma e teorizar sobre o tamanho, peso e velocidade é buscar as características físicas, icônicas que permitem

\footnotetext{
${ }^{5} \mathrm{CP} 2.247$

${ }^{6}$ PEIRCE, 2008, p. 63-64.

${ }^{7}$ CP 2.248

${ }^{8}$ CP 2.299 1893; 2.3041901 apud JORGE 1999, p 41

${ }^{9}$ Op. cit., p. 64

${ }^{10}$ CAMPOS, 2000, p. 81.
} 
estabelecer uma relação entre o volume de areia, a forma da pegada com aquele que a deixou.

Por meio deste entendimento Peirce explica que através de um gráfico de barras podemos estabelecer o vínculo entre as características formais dos retângulos, a área que ocupam no gráfico, com algum dado indicial - o valor de um produto, a taxa natalidade de um país, etc.. O autor afirma que, ao fazermos o estudo de um gráfico, estamos estabelecendo relações formais, proporcionais e, deste modo, estabelecendo relações icônicas.

Porém, estas relações podem ser virtuais, não vinculadas a um objeto real, ou seja, a realidade efetiva do objeto é desnecessária para a possibilidade de sua significação ${ }^{11}$, quer dizer, o objeto não precisa existir no mundo real:

"o ícone não se mantém univocamente para esta ou aquela coisa existente,
como o Índice faz. Seu objeto pode ser pura ficção, assim como sua
existência". 12

Uma vez que o ícone tem como característica a relação formal (a similaridade entre a estrutura do objeto e a representada no e pelo signo), podemos trazer outro exemplo, o raciocínio matemático em álgebra:

\begin{abstract}
"Estou satisfeito por todo raciocínio necessário ser da natureza do raciocínio matemático. É sempre diagramático no sentido amplo, apesar de que as deduções verbosas e soltas dos filósofos devam fazer uso muito mais de diagramas 'auditórios', se esta expressão puder ser permitida, do que dos visuais'. (NEM IV 164 1903)" ${ }^{13}$

"Quando em álgebra, escrevemos relações umas sobre as outras, numa disposição regular, particularmente quando usamos letras semelhantes para coeficientes correspondentes, a disposição obtida é um ícone. (...) Isso é um ícone, pelo fato de fazer com que se assemelhem quantidades que mantém relações análogas com o problema. Com efeito, toda equação algébrica é um ícone, na medida em que exibe, através de signos algébricos (que em si mesmo não são ícones), as relações das quantidades em questão". ${ }^{14}$ [grifo meu]
\end{abstract}

Deste modo:

(1) $a_{1} x+b_{1} y=n_{1}$

(2) $a_{2} x+b_{2} y=n_{2}$

\footnotetext{
${ }^{11} \mathrm{CP} 2.276$

${ }^{12} \mathrm{CP} 4.531$

13 PEIRCE (1903 apud JORGE, 1999, p. 105-106).

14 Peirce, 2008, p. 66.
} 
Esta fórmula genérica pode ser classificada como sendo um signo de primeiridade, ou ícone, devido à relação direta entre elementos com algo, uma condição observada, o objeto de análise. Existe uma correspondência entre a quantidade de elementos "a", "b" e "n" onde, variando duas condições, " $x$ " e "y" estabelecemos a possibilidade de uma verdade " $=$ ". Ainda neste exemplo, temos uma relação de similaridade estrutural entre a fórmula 1 e a fórmula 2 (ambas são compostas por multiplicações e adições de elementos numa seqüencia comum e submetidas às mesmas variáveis " $x$ " $e$ " $y$ ").

Assim, podemos trazer outro exemplo do que seja uma relação icônica:

\begin{abstract}
"A disposição das palavras na sentença, por exemplo, deve servir como Ícones, a fim de que aquela sentença seja compreensível. A principal necessidade dos ícones é para mostrarem as Formas da síntese dos elementos do pensamento. Pois, em precisão de discurso, os Ícones nada podem representar além de Formas e Sentimentos".15
\end{abstract}

"Sentimentos" (feelings), neste caso poderiam ser também entendidos como relacionamentos ou relações como tentamos mostrar anteriormente.

O conceito de ícone, com intuito de representar um substantivo, gera, para Peirce, a definição de hipoícone. Para ele, se um hipoícone estabelece uma relação de primeiridade, uma relação direta e simples com o objeto, podemos chamá-la de imagem. Mas se o signo tem caráter de representar as relações entre presentes na coisa representada por analogia entre as partes do ícone (relações diádicas, segundo Peirce), ele é um diagrama ${ }^{16}$.

\begin{abstract}
"Segundo definição peirceana, o conceito de diagrama figura como uma representação por similaridade nas relações internas das partes do signo e do objeto, além de ser um signo com predominância de um ícone de relações, tendo sua estrutura evidenciada à visão pelo auxílio de convenções (CP 4.418 1903)." 17

“(...) Ícones são o requisito especial para o pensamento. Um Diagrama é, principalmente, um Ícone de relações inteligíveis. (...) quando falamos de raciocínio dedutivo sendo necessário, não queremos dizer, é claro, que ele
\end{abstract}

\footnotetext{
15 "The arrangement of the words in the sentence, for instance, must serve as Icons, is in order that sentence may be understood. The chief need for the Icons is in order to show the Forms of the synthesis of the elements of thought. For in precision of speech, Icons can represent nothing but Forms and Feelings". CP 4.544

${ }_{17}^{16}$ PEIRCE, 2008, p 64.

17 JORGE, $p 120$
} 
é infalível. Mas o que precisamente queremos dizer é que a conclusão é conseqüência das relações explicadas premissas". ${ }^{18}$ [grifo meu]

O que Peirce afirma como "dedução necessária" o pensamento que age a partir de premissas verdadeiras produzindo conclusões verdadeiras ${ }^{19}$.

$\mathrm{Na}$ tentativa de estudar com mais precisão o icônico presente na dedução e no raciocínio matemático, Peirce elabora, através do estudo de diagramas de Euler uma metodologia cujo objetivo é auxiliar o pensamento na busca de verdades. Tal metodologia é desenvolvida no quarto volume de "Collected Papers" sob o nome do estudo Existential Graphs ${ }^{20}$. Neste livro são reunidas as anotações que focam o estudo dos diagramas regidos por regras lógicas de combinação e derivação.

Peirce inicia seus Gráficos Existenciais citando o processo lógico que Leonard Euler desenvolve no livro Letters à une Princese d'Allegmagne, de 1772, a fim de explicitar um processo gráfico que mapeie as relações estabelecidas no raciocínio lógico. Por exemplo:

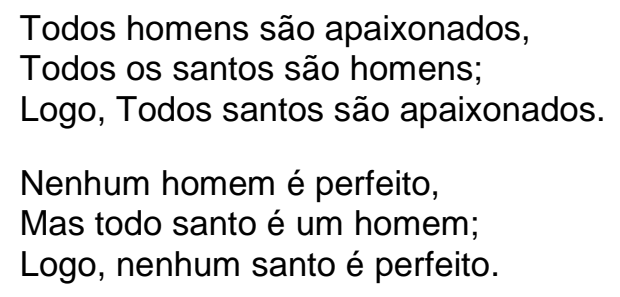

Que foram representados por Euler nas seguintes figuras:
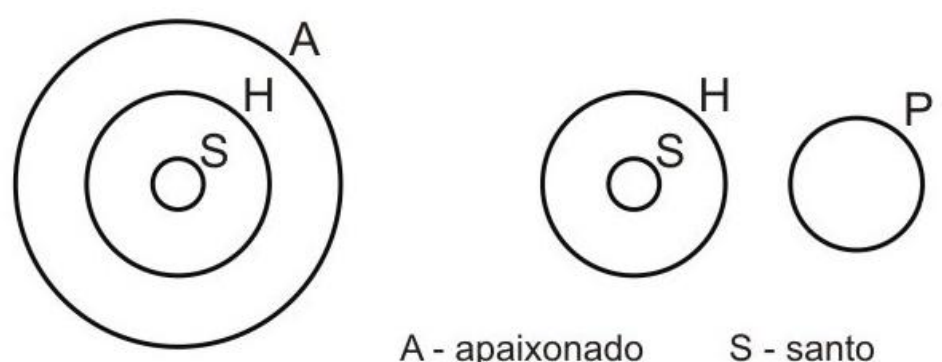

$$
\begin{array}{ll}
\text { A- apaixonado } & \text { S - santo } \\
\text { H- homem } & \text { P-perfeito }
\end{array}
$$

Figura 2.1 Diagrama de Euler

\footnotetext{
18 "(...) Icons are specially requisite for reasoning. A Diagram is mainly an Icon, and an Icon of intelligible relations. (...)when we talk of deductive reasoning being necessary, we do not mean, of course, that it is infallible. But precisely what we do mean is that the conclusion follows from the form of the relations set forth in the premiss". CP 4.531.

${ }^{19}$ Cf. JORGE, 1999. P. 105-106

${ }^{20}$ Aqui será traduzido como "Gráficos Existenciais"
} 
No desenvolvimento de seu raciocínio sobre essa lógica ele define que estes diagramas, baseados em um princípio comum (assim como a lógica depende), podem ajudar a análise de raciocínio e também como uma maneira prática para demonstração clara de idéias. ${ }^{21}$

Peirce desenvolve uma série de diagramas baseados em seis regras de ação pelas quais os elementos que compõem os diagramas são afetados.
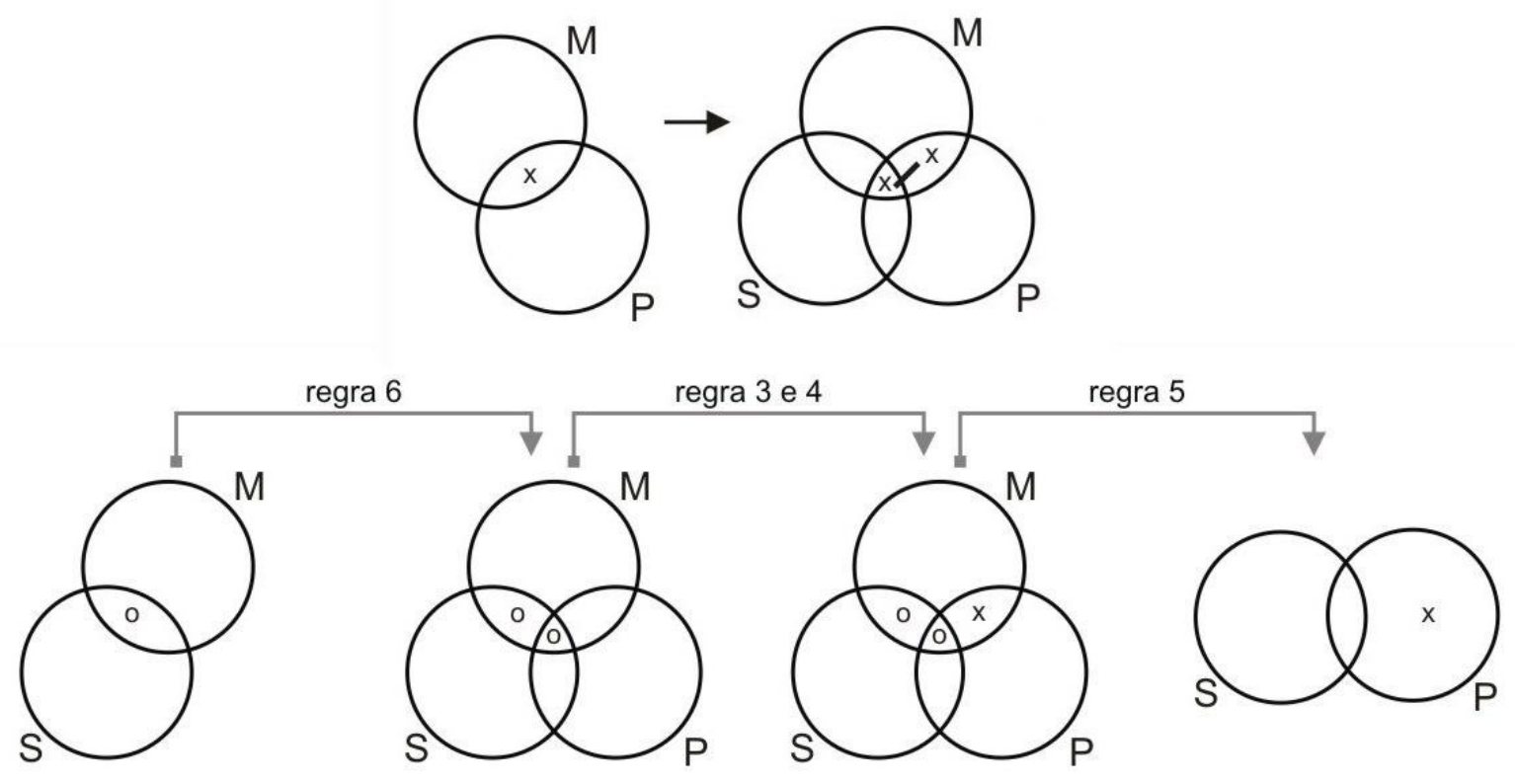

Figura 2.2 Aplicação das regras de composição

Tais regras se baseiam em adição, intersecção e supressão de elementos ${ }^{22} \mathrm{e}$ o que deve ser observado é um procedimento lógico que funda estes processos. A existência ou não de $\mathbf{x}$ ou $\boldsymbol{O}$ nas figuras cria relações entre os elementos $M, S, P$ tal como:

${ }^{21} \mathrm{CP} 4.355$

${ }^{22}$ Tais regras têm certo grau de complexidade e sua descrição neste trabalho não é objeto da pesquisa. O que deve ser registrado é o raciocínio em que se baseiam as regras. 


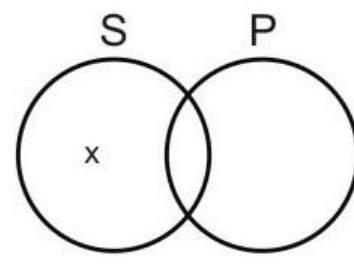

Algum S não é P

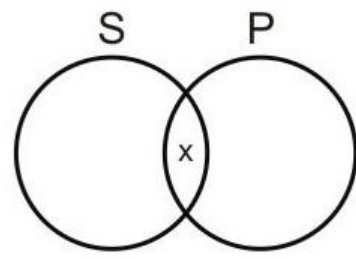

Algum S é P

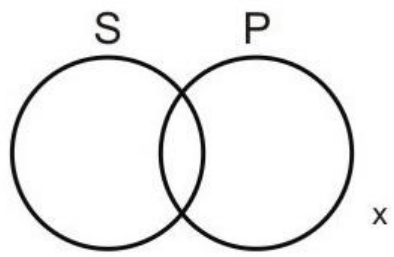

Existe alguma coisa além de $\mathrm{S}$ e $\mathrm{P}$

Figura 2.3 Operações lógicas

Através destas operações, Peirce defende a idéia de que problemas com poucos elementos (apesar de uma vez ter ilustrado este método resolvendo um problema com centro e trinta e cinco círculos) podem ser esclarecidos com tal raciocínio algébrico e nos casos onde o problema é complexo, deveria ser desmembrado em fragmentos menores ${ }^{23}$.

\begin{abstract}
"Embora o estudante não possa ser aconselhado a se confinar em algum método de representação, o sistema de diagramas Eulerianos é provavelmente 0 melhor de qualquer sistema único para a análise puramente não-relativa do pensamento" 24 .
\end{abstract}

Tais diagramas, originados do raciocínio de Euler constituem parte de um conjunto conceitual definido por Peirce como um meio de análise de raciocínio. $A$ definição de tais diagramas pode ser introduzida por:

"Um gráfico é um diagrama superficial composto de uma folha sobre a qual é escrito ou desenhado, de ponto ou seus equivalentes, de linhas de conexão, e (se precisar ser) de fechamentos. O tipo, que é supõe-se mais ou menos parecido, é a fórmula estrutural do químico.

Um gráfico lógico é um gráfico representando relações lógicas iconicamente, assim como é um auxiliar para a análise lógica.

\footnotetext{
${ }^{23}$ CP 4.368 e 4.369 .
}

${ }^{24} \mathrm{CP} 4.370$ 
Um gráfico existencial é um gráfico lógico governado por um sistema de representação fundado sobre a idéia que a folha na qual é escrito, assim como toda porção desta folha, representa um universo reconhecido, real ou fictício, e que todo gráfico desenhado nesta folha, e não separado do seu corpo principal por um fechamento, representa algum fato existente naquele universo, e o representa independentemente da representação de outro fato escrito sobre outra parte da folha, estes gráficos, entretanto, formam um gráfico composto".

Para Peirce, os diagramas traçados em uma folha, declaram uma afirmação; por isso a folha passa a ser chamada de "folha de afirmação" ${ }^{25}$ porque todo gráfico ou tudo que é desenhado na folha, expressa uma proposição que o ato de escrita afirma. ${ }^{26}$

"[...] Nós começamos fornecendo XX uma superfície bi-dimensional onde estes diagramas serão desenhados. Esta superfície pode ser, na verdade, um quadro negro ou uma folha de papel. Para todos os casos, esta superfície será chamada de folha de afirmação (SA). A escrita (ou de outro modo, a colocação) de uma instância gráfica na AS será chamada 'escrever um gráfico' [...]. SA representa, para nós, o 'universo de discurso', ou seja, o domínio de objetos a serem discutidos. Independentemente do que escrevamos sobre ela, pode ser pensado como criar a representação do universo, mais do que determiná-lo (Ms 445, p. 2-3)". ${ }^{27}$

Por conseqüência, se Peirce propõe:

Uma pêra está madura

na SA

Quer dizer, existe uma pêra em nosso universo (de discurso) e ela está madura.

Nesta folha de afirmação trabalham duas entidades, o grapheus e o grafista, sendo o primeiro totalmente aleatório e imaginativo enquanto o grafista é a pessoa que concebe o universo perfeitamente definido.

O grapheus cria o universo pelo desenvolvimento contínuo de sua idéia sobre ele. Em todo momento, a cada intervalo de tempo ele adiciona algum fato ao universo, produz afirmações até que o pensamento toma corpo, adquire seu ser, sua

\footnotetext{
${ }^{25}$ Sheet of assertion, no original em inglês.

${ }^{26} \mathrm{CP} 4.430$

27 "[...]we begin by providing for a two-dimensional surface on which these diagrams are to be drawn. This surface may in practice be a blackboard, or it may be a sheet of paper. In any case it will be called the 'sheet of assertion' (SA). The writing (or otherwise placing) of a graph-instance on SA will often be called 'scribing a graph' [...]. SA represents for us the 'universe of discourse', that is, the domain of objects to be talked about. Whatever we write upon it can be thought of as making the representation of the universe more determinate (Ms 455, pp. 2-3)". ROBERTS, 1973, p. 31.
} 
perfeita definição até que, no momento que toda operação se completa, o universo adquire existência, ou seja, total determinação.

Já o grafista, está ocupado durante o processo fazendo constantes modificações em todo gráfico. Este não é um processo contínuo uma vez que cada modificação, a não ser que seja a final, possui outra que a sucede.

O que Peirce quer com a convenção acima, de grapheus e grafistas, é estabelecer o raciocínio sob qual o processo de seus gráficos existenciais atua com o objetivo da criação de um método cujo mecanismo é representar e afirmar diagramaticamente qualquer conjunto possível de premissas afirmadas. O diagrama se mostraria como aquilo que observamos nas transformações destas premissas em direção a uma conclusão através de uma série de etapas caracterizadas pela sua simplicidade lingüística. Mas as afirmações realizadas e apreendidas não são como um cenário físico onde cada verdade percebida está sob uma lei da natureza, mas como o que ele chama de "necessidade da lógica" ${ }^{28}$ que consiste em determinar algo como verdadeiro em um mundo ainda não determinado.

O branco da folha branca pode ser considerado como a expressão de um universo que, em processo de criação do grapheus, é "perfeitamente definido e completamente determinado" ${ }^{29}$. Vemos aqui o mesmo raciocínio de um positivismo sobre o saber do mundo como o exposto no primeiro capítulo. Um universo que não está determinado, caótico, mas por forças da atividade lógica, se determina e se ordena.

Afinal, qual a razão de existência dos diagramas matemáticos de Peirce? Ele mesmo responde em um diálogo com um general:

\footnotetext{
"Mas porque fazer isso [uso de diagramas] quando o pensamento por si só se apresenta a nós? (...) General, você faz uso de mapas durante uma campanha, eu creio. Mas porque deveria fazê-lo quando o país que eles representam está logo ali?' Ele então respondeu que encontrou detalhes nos mapas que estariam muito longe de estarem 'logo ali'. '(...) Estou certo, então, entender que, se você fosse cuidadoso e perfeitamente familiarizado com o país (...) nenhum mapa poderia ser de menor uso em expor seus planos detalhados para você?(...) Não, eu não disse isso, uma vez que eu possivelmente desejaria colocar pinos, assim como marcar as mudanças de cada dia antecipadamente nas situações de dois exércitos.(...) Bem, General, isso corresponde às vantagens de um diagrama no curso de uma
}

\footnotetext{
${ }^{28}$ Logical necessity, no original em inglês.

${ }^{29} \mathrm{CP} 4.432$
} 
discussão. Com efeito, exatamente onde o senhor apontou, encontra-se a vantagem dos diagramas em geral. Isto é, se eu puder esclarecer-lhe o assunto, podem-se fazer experimentos exatos sobre diagramas uniformes; e quando isto é feito, pode-se observar de modo inteiramente privilegiado mudanças não intencionadas e não esperadas ocorridas nas relações mantidas entre diferentes partes significantes do diagrama. Tais operações sobre diagramas, sejam elas exteriores ou imaginárias, tomam o lugar dos experimentos sobre coisas reais, realizados na pesquisa química e física. Os químicos têm, até agora, descrito a experimentação como questões colocadas à Natureza. Desse modo, os experimentos realizados sobre diagramas são questões colocadas à natureza das relações concernidas. Nesse momento, o General teria sugerido [...] que haveria uma grande diferença entre experimentos como os do químico, que são experimentos feitos sobre a própria substância cujo comportamento está sendo questionado e experimentos feitos sobre diagramas, não tendo estes últimos qualquer conexão física com as coisas que eles representam. A única resposta adequada, notando-se que perfeitamente uma pessoa pouco familiarizada com Lógica poderia se confundir, seria esta: $\mathrm{O}$ senhor tem toda razão ao dizer que o químico experimenta sobre o próprio objeto da investigação, conquanto, depois do experimento feito, a amostra com que ele trabalhou pudesse ser jogada fora, não por qualquer interesse posterior, pois não era aquela amostra particular que o químico estava investigando; era, isto sim, a estrutura molecular. Com efeito, o químico estava há muito tempo de posse de poderosa prova de que todas as amostras de mesma estrutura molecular reagem quimicamente do mesmo modo, de maneira que uma amostra equivale a qualquer outra. Entretanto, o objeto de pesquisa do químico, aquilo sobre o qual ele experimenta, e ao qual se refere, a pergunta que ele coloca à Natureza, é a Estrutura Molecular, a qual em todas suas amostras tem uma identidade tão plena quanto a da natureza da Estrutura Molecular tem de possuir. Deste modo, como você disse, ele experimenta sobre o Próprio Objeto da investigação. Mas se você parar por um momento para considerá-lo, irá perceber, eu acho, que você cometeu um erro ao dizer que é de outra forma que experimentos são feitos a cerca de diagramas. Qual é o Objeto de Investigação? É a forma de uma relação [grifo do autor]. Esta forma de relação é exatamente a forma da relação entre duas partes correspondentes do diagrama'". ${ }^{30}$

\section{Para deixar claro esse raciocínio ele mostra o exemplo a seguir:}

$$
\frac{1}{f 1}+\frac{1}{f 2}=\frac{1}{f 0}
$$

"'Esta equação é um diagrama da forma da relação entre as duas distâncias focais e a distância focal principal; e as convenções da álgebra (e todo diagrama depende de convenções) em conjunto com a escritura da equação, estabelecem uma relação entre as próprias letras $f 1, f 2, f 0$ independentemente de sua significação, de modo que a forma das relações que as letras mantêm entre si é exatamente a mesma das relações entre as três distâncias focais que as letras denotam"'."31

Ou seja, neste caso, a soma das distâncias focais nesta fórmula matemática é a mesma relação no mundo real. Adicionando uma lente, com uma distância focal a

${ }^{30} \mathrm{CP} 4.530$

${ }^{31} \mathrm{CP} 4.530$ 
outra, cria-se uma terceira composta pela soma - que é a relação real entre as lentes.

'Muitos diagramas não se assemelham, de modo algum, com seus objetos, quanto à aparência: a semelhança entre eles consiste apenas quanto à relação entre suas partes'. ${ }^{32}$

\footnotetext{
"Então, à medida que são construídos objetos matemáticos, ou geométricos, expõem-se esses objetos para a visão tal como eles são. Estabelece-se, portanto, na forma de um esquema, aquilo que é experienciado na forma de um conceito". ${ }^{33}$
}

A base para entendimento do conceito de diagrama de Peirce vem do entendimento da relação icônica que é estabelecida entre o signo e o objeto, mas essencialmente desta frase:

"A matemática estuda o que é logicamente possível sem partir da existência atual do fenômeno". ${ }^{34}$

Tomada de Ana Maria Guimarães Jorge, esta frase poderia ser facilmente de autoria de Peirce, uma vez que ele defende a possibilidade de adquirir um conhecimento a priorístico, ainda não experimentado no universo real, mas que por meio de uma racionalização matemática, tem a possibilidade plena de sua formação em tal ambiente especulativo onde são preparadas e observadas as variáveis e questões colocadas por meio de um modelo teórico chamado de diagrama.

Mas para Peirce, este diagrama é um método originado para suprir (ou possibilitar) o conhecimento que ele define como raciocínio dedutivo ilativo (colorário) ou teoremático. ${ }^{35}$

O raciocínio dedutivo colorário é feito a partir da representação de condições sobre um diagrama e, através da observação deste, tal como ele é, retira-se a conclusão.

Por sua vez, o teoremático implica, além de uma representação das condições tal como o colorário, "engenhosos experimentos" sobre o diagrama para, a partir deste diagrama modificado, realizar a observação e a retirada da conclusão.

\footnotetext{
${ }^{32}$ CP 2.282; apud PEIRCE 1996: 66

33 JORGE, 1999, p. 73-74

${ }^{34}$ Ibid., p. 104.

${ }^{35}$ CP 2.267
} 
Tal diagrama teoremático é particularmente interessante pelo enfoque matemático que Peirce dá a seus gráficos. No caso do diagrama teoremático ele diz ser oposto ao raciocínio que os filósofos têm (que seria corolário, que parte de uma proposição derivada de outra, baseada em uma argumento lógico tal como o tradicional exemplo Aristotélico "todo homem é mortal. Sócrates é homem, logo, Sócrates é mortal"), mas se constitui da formação de um esquema ou uma figura composta com linhas, letras ou até uma série de formulações algébricas na tentativa de descrever uma hipótese em termos gerais (i. e. registrar as condições do diagrama) criando uma imagem visual através deste esquema, ou seja, uma espacialidade das relações.

O método diagramático:

"consiste em estudar construções ou diagramas [...], pois mesmo em
álgebra, o grande propósito do simbolismo ${ }^{36}$ presta-se a apresentar uma
representação estrutural das relações, concernentes ao problema, diante
dos olhos da mente, em uma forma esquemática que pode ser estudada
tanto quanto o são as figuras geométricas" ${ }^{37}$.

Ora, o que Peirce parece propor com o método é a transformação de um processo estritamente mental para visual uma vez que, no diagrama mental, as relações das partes são estabelecidas, por analogia, com as partes do objeto. A partir do momento que estas relações foram criadas, elas são experimentadas "na imaginação" a fim de, no resultado, descobrir "relações ocultas e despercebidas entre as partes". ${ }^{38}$

Peirce, em vários momentos menciona uma estrutura oculta no raciocínio onde os diagramas, como método dedutivo, possibilitam uma "visão clara" sobre o modo de conexão e composição entre partes.

Até o presente momento dessa dissertação, podemos identificar um diagrama baseado em premissas lógicas, analíticas e estruturais, seja para descrição ou exposição de estruturas não-evidentes que de alguma forma parecem possuir uma verdade oculta até então alheia ao conhecimento.

\footnotetext{
${ }^{36}$ Podemos definir alguns caracteres matemáticos como símbolos matemáticos (p. ex: $\Sigma,+, \equiv, \sqrt{ }$, etc.) porque agem sob força de lei, conforme a explicação dada no deste capítulo.

${ }^{37}$ CP 3.556 apud JORGE 1999, p 107.

${ }^{38} \mathrm{CP} 3.556$
} 
A maneira mais apropriada para classificarmos estes diagramas talvez seja sob o conceito de estrutura tal como desenvolvido na metade do século $X X$, originalmente pela lingüística e suas derivações conceituais na antropologia, filosofia, arquitetura, sociologia, etc. Todos estes diagramas mostram o conceito (senão "os conceitos") semiótico de Peirce através de um mecanismo metodológico composto por símbolos (tal como o $\mathbf{x}$ e 0 da figura 2.2) organizados por linhas que representam a situação real. $O$ diagrama pode ser entendido como esta imagem final composta pelas linhas que estabelecem um acontecimento na "folha de afirmação" sob orientação do grapheus e do grafista que podem ser mais bem entendidos como duas entidades sob a mesma pessoa que desenha nesta folha. Enquanto o grafista determina uma condição, uma verdade que diagrama relações no papel (como uma linha), tal desenho é originado por motivação de uma mente caótica e arbitrária, o grapheus. ${ }^{39}$

Portanto, poderemos falar de uma diagramática no momento que observamos a relação entre elementos numa sentença se estabelece como a realizada na condição real de onde ela surge. Conseqüentemente falaremos de diagrama como a imagem mental destas relações, mas que pode ser impressa em variados suportes, e de variadas maneiras, obedecendo as mesmas relações.

Vemos os diagramas arquitetônicos do início do século $X X$ descrevendo ações nas habitações, ou tentando descrever o mundo imediato por suas conexões e interações entre elementos e todos eles têm o enfoque não na metafísica de um sujeito, mas nas conseqüências de sua existência, na fenomenologia.

Mas uma pergunta surge: Serão todos diagramas relacionais? Será que podemos estabelecer a semiótica peirceana como aquela que resumiu o conceito de diagrama que trazemos na arquitetura?

Um apontamento para esta pergunta é dado pela mesma semiótica que procura a elucidação do pensamento através de mapas-resumo. É na frase "um diagrama deve ser tão icônico quanto possível" ${ }^{40}$ que fazemos referência a um

\footnotetext{
${ }^{39} \mathrm{CP} 4.432$

${ }^{40} \mathrm{CP} 4.433$
} 
desenvolvimento do conceito de ícone trazido por Fenollosa ${ }^{41}$ em seu estudo sobre os ideogramas chineses.

Tal estudo é apresentado por Haroldo de Campos no livro "Ideograma: Lógica, Poesia, Linguagem" e é através dele e da qualidade icônica latente pertencente aos kanjis, outra relação diagramática que aparece no/pelo diagrama trabalhado na arquitetura a partir dos anos 90 , sob conceito de máquina abstrata.

${ }^{41}$ Ernest Francisco Fenollosa (1853-1908) - The Chinese Writen Character as a Medium for Poetry, publicado por Erza Pound em 1919. 


\section{1 - Os Ideogramas de Fenollosa}

Fenollosa menciona ${ }^{42}$ que o par "sol" + "lua" na língua chinesa ora corresponde a substantivo, ora a verbo ou adjetivo. Os ideogramas não fazem parte do discurso, mas se dispõem como convém, com as relações que estabelecem com os ideogramas vizinhos. A essência da escrita de ideogramas é, no entendimento semiótico, diagramática.

\section{日 “Sol” 月 “Lua” 明 “Sol+Lua”}

Em chinês, a palavra ming ou mei possui o ideograma composto pelo kanji "sol"+"lua" pode ser traduzido como brilhante(adjetivo), brilha(verbo) ou brilho(substantivo). Assim, uma taça "sol+lua" brilha; "sol+lua" da taça é o brilho da taça; "sol+lua" taça é uma taça brilhante, reluzente.

Reduzir as palavras "Sol+Lua" a uma simples palavra específica como "brilho" é o mesmo que, na escrita ocidental, reduzirmos as kenningar ${ }^{43}$ da poesia Escandinávia a um substantivo - suor da guerra: sangue; mar de espadas: batalha.

Deste modo, Campos define a palavra chinesa como palavra subjacente porque não pertence a nenhuma parte do discurso, mas seu significado é interno e abrangente. Ela pode se comportar de maneiras diferentes cada qual dependente do seu entorno.

Campos, em sua interpretação de Fenollosa, mostra como o kanji é visto segundo um processo relacional, uma metáfora estrutural e não como um pictograma, uma representação de idéias. Fenollosa menciona um exemplo que deixa clara essa relação quando sugere que japoneses fariam a observação de um quadro não do modo convencional, mas colocando-o de cabeça para baixo a fim de perceberem as relações, as pinceladas e os elementos de cor, refutando a mimese

\footnotetext{
${ }^{42}$ FENOLLOSA, Ernest. in CAMPOS, 2000, p. 123.

${ }^{43}$ BORGES, 2001a, p. 35-55.
} 
da natureza na imagem do quadro, ou seja, "as relações são mais importantes e mais reais do que as coisas por elas relacionadas". ${ }^{44}$

O ideograma não se comporta como uma síntese de uma idéia em um kanji, ou seja, "uma pintura de idéias via coisas", uma representação pictórica de um real, tal como um desenho que expressa uma ação, mas um processo de relações entre signos:

$$
\begin{aligned}
& \text { 林 Bosque (árvore + árvore) 王 } \begin{array}{c}
\text { Governante, rei, aquele que liga os } \\
\text { três planos }
\end{array} \\
& \text { 休 Descansar (homem+árvore) 玉 Jóia (rei + ponto) } \\
& \text { 森 Floresta (árvore x3) 好 Gostar, apaixonado (mulher + filho) }
\end{aligned}
$$

O ideograma, segundo Fenollosa surgiu de uma passagem de um visível a um invisível através da metáfora, ou seja, "a utilização de imagens materiais para sugerir relações imateriais ${ }^{45}$ ".

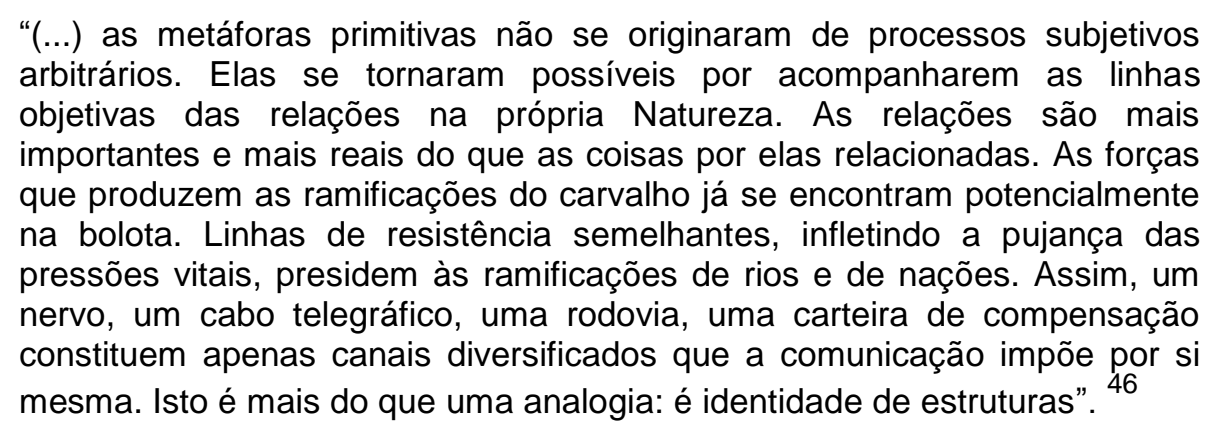

Podemos ver o ideograma como um diagrama porque estabelece relações entre os elementos que o compõe, mas com expressão metafórica.

A imagem expressa não é completa por um significado, mas é potente. A potência das "forças do carvalho que são encontradas na bolota" não é exaurida. Ela ainda contém possibilidades de relações em outras situações (tal como 明 pode ser verbo, substantivo ou adjetivo).

\footnotetext{
${ }^{44}$ FENOLLOSA. In CAMPOS, 2000, p. 109-148.

45 Ibid., loc. cit.

${ }^{46}$ Ibid., loc. cit.
} 
Assim, o ideograma permite estabelecer relações variáveis, mas relações metafóricas. O potencial significante do ideograma é devido à não-limitação do significado de sua imagem. Lembramos que um ideograma isolado, um kanji, tem como finalidade representar um objeto (seja uma ação, ou substantivo (sol), ou uma condição). Em sua aproximação de outro kanji é estabelecida uma relação, tal como Peirce definiu sobre a folha de afirmação: duas sentenças separadas numa mesma folha podem ser diagramadas como contíguas. O que acontece diferente em uma contigüidade por ideogramas e por sentenças é o caráter verbal que condiciona a escrita ocidental. Duas sentenças verbais delimitam uma condição, uma ação e descrevem como deve se comportar o objeto representado na frase.

A polpa de algumas laranjas é vermelha.

Expressar a si mesmo naturalmente é perfeição final da arte de um escritor.

Por mais independentes que sejam estas duas sentenças, a proximidade entre elas induz à criação de uma relação (portanto, um diagrama) em direção à busca de um significado. $\mathrm{Na}$ existência de verbos ${ }^{47}$ essa direção é delimitada, mas numa sentença não verbal (p.ex: uma poesia), a relação nunca é estanque.

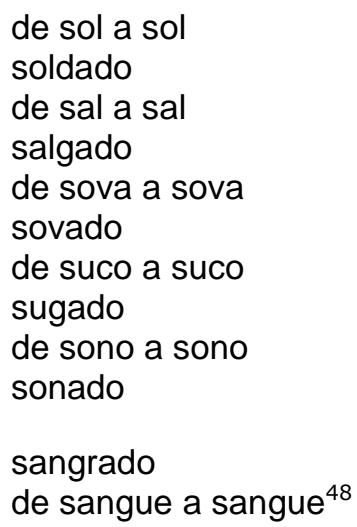

"Para além de seu ritmo, a forma tipográfica do versículo serve para anunciar ao leitor que a emoção poética, não a informação ou o raciocínio, é o que o espera". ${ }^{49}$

O tema principal que queremos destacar é o entendimento de Fenollosa em que "as relações são mais importantes e mais reais do que as coisas por elas relacionadas". Esse tema desenvolve a percepção de uma condição geradora no

\footnotetext{
${ }^{47}$ To be, em inglês expressa melhor tal pensamento: ser /estar.

${ }^{48}$ Haroldo de Campos. In: BOSI, 1999, p. 479.

${ }^{49}$ BORGES, 2001b,
} 
ícone. Se uma imagem representa exatamente o objeto e um diagrama, as relações podem ser determinadas, segundo Peirce, como ícones. Mas ao observarmos uma figura ou uma poesia que não define certezas, (por não possuir verbo) criamos emocionalmente ou mentalmente outro conjunto de relações. Se uma imagem mobiliza um conjunto de emoções em um observador, foi por motivações internas que estas se mobilizaram. Esse potencial significativo é o mesmo que foi citado por Fenollosa, como um potencial latente, inerente ao ideograma. Vejamos a passagem a seguir:

\begin{abstract}
"Quanto mais concreta e vividamente expressamos as interações das coisas, melhor é a poesia. Em poesia, necessitamos de milhares de palavras ativas, cada qual fazendo o máximo para revelar as forças nutrizes e vitais. Não podemos exibir a opulência da Natureza por simples adição, amontoando sentenças. O pensamento poético trabalha por sugestão, acumulando o máximo de significado numa única frase replena, carregada, luminosa de brilho interior.

Nos caracteres chineses, cada palavra acumula em si mesma essa espécie de energia". ${ }^{50}$
\end{abstract}

Esta energia é o que Fenollosa descreve posteriormente quando compara os textos de Shakespeare com a língua oriental. Ele mostra que, assim como a língua chinesa, Shakespeare não corresponde ao uso do verbo é (is). Essa definição (base da análise dos gráficos existenciais de Peirce - A é B, B é C $\therefore$ A é C) fundamenta a língua ocidental, mas é inexistente na língua oriental que é regida basicamente por comportamentos não-verbais: "reading promotes writing" a leitura promove a escrita, em inglês, seria escrita em chinês como algo próximo de "ler promover escrever" ${ }^{51}$.

Retomemos, neste sentido, a uma frase significativa no texto de Fenollosa:

"Uma análise das línguas arianas leva-nos a suspeitar que essas diferenças [comparando a língua chinesa com "as boas línguas cristãs", a existência ou não de pronomes, preposições e conjunções] não são naturais e que foram em má hora inventadas pelos gramáticos para complicar a visão simples e poética da vida. Todas as nações produziram a sua literatura mais poderosa e vívida antes de inventarem a Gramática. (...) A Natureza, ela própria, não tem gramática. Imaginem só, tomar-se um homem e dizer-Ihe que ele é um nome, um substantivo, uma coisa morta em seu lugar de um feixe de funções!"52

O ideograma fenollosiano é carregado de uma "energia potencial" derivável, pertencente à poesia e alheia à clausura. Ora, vemos nesta descrição um conceito

\footnotetext{
${ }^{50}$ FENOLLOSA. In CAMPOS, 2000. p. 132.

${ }^{51}$ Apesar de ser composta por verbos, esta sentença não deveria ser identificada como verbo porque, sem um agente e um predicado, o verbo não adquire significância definida.

${ }_{52}$ Op. cit., p. 121-122.
} 
de língua não definido por convenções ou leis abstratas, mas um relacionamento constante, icônico, que evita a gramática restritiva, sintática, estrutural.

Na percepção da existência de um tema gerativo como tal, e comparativamente com a expressão icônica evidente em Fenollosa, podemos relacionar tal pensamento com o derivado na França, a partir da década de 60, quando acontece um questionamento sobre a perpetuação de modelos sociais e a supressão da vontade do sujeito. Neste sentido devemos trazer outro conceito de diagrama, atualmente discutido em arquitetura como máquina abstrata deleuziana, um mecanismo de devires, de revelação de potências latentes do homem, até então reprimidas pelas condições sociais. 
[Análise do conceito de diagrama em

Deleuze e Guattari] 


\section{CAPÍTULO 3 - A visão do diagrama pela filosofia de Deleuze e Guattari}

O ideograma fenollosiano é carregado de uma "energia potencial" derivável, pertencente à poesia e alheia à clausura. Vemos nesta descrição um conceito de língua não definido por convenções ou leis abstratas, mas um relacionamento constante, icônico, que evita a gramática restritiva, sintática, estrutural.

$\mathrm{Na}$ percepção da existência de um tema gerativo como tal, e comparativamente com a expressão icônica evidente em Fenollosa, podemos relacionar tal pensamento com o derivado na França a partir da década de 60, quando acontece um questionamento sobre a perpetuação de modelos sociais e a supressão da vontade do sujeito. Neste sentido devemos trazer outro conceito de diagrama, atualmente discutido em arquitetura como máquina abstrata deleuziana, um mecanismo de devires, de revelação de potências latentes do homem, até então reprimidas pelas condições sociais.

Nos anos 60, em um ambiente social que despertava para uma mudança, o pensamento era habituado em uma percepção plena de classificações conceituais.

Tal momento era tomado pelo estruturalismo como uma ótica de mundo, tal como afirma Solà-Morales:

"Mais que uma filosofia, o estruturalismo se apresentava como um método. Um instrumento explicativo da realidade que, nascido de uma lingüística formalista do círculo de Praga, se via facilmente ampliado à antropologia, às ciências sociais e, diretamente à literatura e a arte". ${ }^{1}$

Para entender o momento que o mundo passava, Perrone-Moisés ${ }^{2}$ nos traz 0 esclarecimento de que tal concepção de mundo se firma na França dos anos 60, mas com vida curta, uma vez que alguns filósofos contestam seu idealismo universalizante. Dentre os filósofos que questionam a interpretação da lingüística como "ciência-piloto", Perrone-Moisés cita Michel Foucault, contestando a Razão

\footnotetext{
1 "Más que una filosofía, el estructuralismo se presentaba como un método. Un instrumento explicativo de la realidad que, nacido de la lingüística formalista del Círculo de Praga, se hacía extensivo con toda facilidad a la antropología, las ciencias sociales, el derecho, la literatura y el arte". SOLÀ-MORALES, 2003, p. 81.

2 PERRONE-MOYSÉS, 2004, p. 213.
} 
como forma de poder (História da Loucura da Era Clássica, 1961) propondo a "genealogia do saber" em 1966, mas também Gilles Deleuze, trazendo à tona "o jogo da diferença" em 1962 e Derrida que "minou as bases do estruturalismo, ao criticar o idealismo do signo segundo Saussure, os modelos racionalizantes usados na lingüística [...] (A Escritura e a Diferença, 1967)" ${ }^{3}$. Assim acontece o momento de passagem do estruturalismo para um pós-estruturalismo ${ }^{4}$.

Nesta década de 60, é preciso destacar o ano de 1968 como o momento chave onde acontece uma série de eventos no mundo, como o fechamento da faculdade de Filosofia da USP após o confronto dos estudantes desta unidade com os do Mackenzie na "Batalha da Maria Antônia"; prisão de 1200 alunos em uma reunião da UNE em Ibiúna; Ofensiva do $\operatorname{Tet}^{5}$ no Vietnã; ocupações de universidades nos Estados Unidos como protesto ao assassinato de Martin Luther King e o "Agosto de Chicago" 6 que foi tido como o "Maio de 68" nas Américas.

Mas é na França que o ano de 68 toma amplitude quando acontecem manifestações de descontentamento através da emergência de partidos operários questionando a direção tradicional do trabalho (até então baseada em um modelo fordista) e também algumas revoltas estudantis movidas por leituras de Sartre, buscando direitos civis e das minorias e repudiando a Guerra do Vietnã.

"Não é somente o sujeito, mas também os sujeitos tomados em sua intersubjetividade que fazem a fila... e que modelam seu ser mesmo sobre o momento da cadeia significante que os atravessa... O deslocamento do significante determina os sujeitos em seus atos, em seu destino, em suas recusas, em suas cegueiras, em seus sucessos e em sua sorte, não obstante seus dons inatos e sua aquisição social, sem levar em conta 0 caráter ou o sexo...." ${ }^{7}$

Sob este aspecto compartilhado pela filosofia pós-estruturalista que desenvolvemos o tema imanente aos seus conceitos que é o conceito de virtual.

\footnotetext{
${ }^{3}$ PERRONE-MOYSÉS, 2004. p. 215.

${ }^{4}$ Um fato curioso que Leyla Perrone-Moysés traz é que os prefixos "pós" foram todos introduzidos pelos americanos. Cf. Ibid., p. 217.

${ }^{5}$ Tal ato foi um ataque norte-vietnamita contra o exército estadunidense antecipando o fim da guerra do Vietnã.

${ }^{6}$ Durante dias pessoas e grupos (no dia 24 haviam 10.000 pessoas) se aglomeravam no Parque Lincoln movidos inicialmente por uma tentativa de executar um evento hippie chamado Festival da Juventude, mas que fora proibido dias antes pela prefeitura por temer um potencial destruidor inerente que poderia acabar em desordem generalizada. No dia 24 a polícia desmanchou o evento de forma truculenta e atacou qualquer pessoa que estivesse no local. O governo havia enviado à cidade mais de 26.000 militares (dentre eles soldados, policiais, agentes do Serviço Secreto e da Guarda Nacional). Cf. PERICÁS, 2008.

${ }^{7}$ LACAN (1966 apud CHÂTELET, 1974, p. 277).
} 
Segundo Eladio Craia $^{8}$, existem dois pares conceituais importantes a serem considerados em Deleuze, o par possível-real e o potencial-atual.

A cada par determina-se um processo. No possível-real algo possível pode se tornar realizado, mas neste processo nada muda de seu estado anterior a um seguinte, só acrescenta existência a algo que ainda não aconteceu. A chuva que cai nada mais é que algo que aconteceu de um estado possível anterior. "Não existe criação na realização, pois nada de inovador é adicionado no processo, nem em termos de forma nem de 'Idéia". 9

Já no par potencial-atual o processo é uma atualização. Em um primeiro estágio existe um devir imanente que "devém" no movimento de se atualizar. Existia um estágio potencial, uma vontade de potência, uma virtualidade que é atualizada na exterioração desta potência. Mas neste processo de derivação, de algo derivar-se em um segundo, ainda é mantida uma relação interna ao contrário do que acontece no par possível-real. Mas não devemos seguir este raciocínio entendendo este virtual, esta condição de devir como uma potência interna que é desperta e que transforma. Este conceito, como esclarece Craia, é oriundo da escolástica no Medievo:

\footnotetext{
"Para a filosofia medieval, o virtual é aquilo que está em potência, que ainda não foi atualizado. Assim sendo, o virtual parece necessitar de uma passagem na qual, ao mesmo tempo, se completa e desaparece. Com efeito, quando o virtual (ou potencial) é atualizado, ele deixa, literalmente, de "ser aquilo que era", para tornar-se outra coisa; sua natureza muda, o ser virtual se perde no surgimento do ser atual". ${ }^{10}$
}

Craia descreve que essa "força de potência" é trazida pela escolástica na Idade Média, mas como uma negatividade. Isso implica que para ser algo o ser deve-se deixar de ser o anterior tal como a dualidade pecador $\rightarrow$ imaculado.

Craia, também traz o exemplo da semente que se torna árvore, tal como o de Fenollosa mostrado no capítulo anterior.

"Semente e árvore não são o mesmo, mas o segundo momento só pode ser atualizado, se, e só se, há certa relação direta e reconhecida entre ambos os pólos, uma árvore só se encontra em potência em uma semente, e não em uma rocha". ${ }^{11}$

\footnotetext{
${ }^{8}$ CRAIA, 2009, p. 120.

9 lbid., loc. cit.

10 lbid., p. 113.

11 lbid., p. 120.
} 
Se observarmos, essa metáfora pode nos trazer a negatividade mencionada quando interpretamos que a semente transcende seu estado e se torna outra em um estado posterior, ou seja, a árvore estava em potência na semente. Existia uma força de potência que é reproduzida em um processo de transformação, mas sempre regido por esta "essência" ou interioridade intrínseca à semente. Da semente nada poderia sair senão uma árvore. Mas o autor demonstra que o processo que transita é outro. Ao invés de termos esta interpretação essencialista do processo, este deve ser o que Deleuze chama de "dramatização" ${ }^{12}$. Eladio nos explica que na dramatização, um virtual é atualizado, uma diferença se acrescenta no advento do atual, mas esta diferença não é trazida ou explicitada pela essência, mas por uma problemática.

\begin{abstract}
"Atualizar por dramatização é colocar de modo atual uma solução determinada para um problema mantido como puro virtual, e não como potencial, em um nó problemático. Virar arvore é um dos 'problemas da semente', uma vez que a semente é um nó de problemas, mas o tipo de solução e o modo da dramatização não se encontram no problema". ${ }^{13}$
\end{abstract}

Assim, a atualização é uma solução, mas não estava contida no enunciado. Ocorre uma criação a partir de uma problematização, uma forma que surge "a partir de uma configuração dinâmica de forças e finalidades". Mas esta solução não é como tradicionalmente conhecemos, por exemplo, na lógica matemática. Uma solução não esgota o problema, "a solução desdobra o problema em um campo fenomênico determinado". O papel do problema neste processo é de orientar, condicionar e engendrar as soluções que não se assemelham às condições do problema $^{14}$.

\footnotetext{
"um vivente não se define só geneticamente pelos dinamismos que determinam seu meio interior, mas também ecologicamente pelos movimentos externos que presidem sua distribuição no extenso". ${ }^{15}$
}

Essa é a natureza do drama deleuziano. Em uma pesca, como ele nos mostra $^{16}$, muitas ações podem ocorrer dentro do objetivo de captar um peixe. Podemos lançar linhas, atingi-lo de cima para baixo, de baixo para cima... E do mesmo modo, 24 elementos celulares podem ocorrer de várias formas: (12x2), $(2 \times 10)+(2 \times 2)$ ou até mesmo $(2 \times 4)+(2 \times 8)$.

\footnotetext{
${ }^{12}$ Cf. DELEUZE, 2006a, p. 304-309.

${ }^{13}$ CRAIA, 2009, p. 120.

${ }^{14}$ DELEUZE, op. cit., p. 299.

15 Ibid., p. 305.

${ }^{16}$ lbid., p. 304.
} 
Ora, como arquitetos, deveríamos entender este processo com mais propriedade. Um projeto de arquitetura nada mais é que uma hipótese a um dado problema. Dois arquitetos têm diferentes projetos sobre um mesmo programa (um problema) em um mesmo terreno. A formulação de um projeto, nada mais é que a formulação de uma hipótese.

Assim, a natureza e virtualidade do ser é que permitem a constituição de multiplicidades e, conseqüentemente, uma expressão da dinâmica que ocorre no processo ${ }^{17}$.

“(...) todo conceito, tendo um número finito de componentes, bifurcará sobre outros conceitos, compostos de outra maneira, mas que constituem outras regiões do mesmo plano, que respondem a problemas conectáveis, participam de uma co-criação. Um conceito não exige somente um problema sob o qual remaneja ou substitui conceitos precedentes, mas uma encruzilhada de problemas em que se alia a outros conceitos coexistentes". 18

Ou ainda:

"o conceito de um pássaro não está em seu gênero ou sua espécie, mas na composição de suas posturas, de suas cores e de seus cantos". ${ }^{19}$

A característica do kanji de Fenollosa poderia ser entendida não como uma condição essencial de realização, mas como uma atualização propiciada pela sua relação com um outro.

"Não se perguntará nunca o que um livro quer dizer, significado ou significante, não se buscará nada compreender num livro, perguntar-se-á com o que ele funciona"20

O que Deleuze traz neste momento é o conceito que este devir é composto não por definições originais ("um livro não tem objeto nem sujeito"), mas por linhas, viscosidades e movimentos (de territorialização e desterritorialização) que constituem o que ele chama de agenciamento.

\footnotetext{
${ }^{17}$ Cf. CRAIA, 2009, p. 123.

${ }^{18}$ DELEUZE; GUATTARI, 1997b, p. 30.

${ }^{19}$ lbid., p. 32.

${ }^{20}$ DELEUZE; GUATTARI, 1995a, p. 12.
} 
O que é um agenciamento? Deleuze e Guattari respondem:

"O agenciamento só é enunciação, só formaliza a expressão, em uma das faces; em outra face inseparável, ele formaliza os conteúdos, é agenciamento maquínico ou de corpo. Ora, os conteúdos não são 'significados' que dependeriam do significante de uma maneira ou de outra, nem 'objetos' que estariam em uma relação de causalidade qualquer com um sujeito. Por possuírem sua formalização própria, eles não têm qualquer relação de correspondência simbólica ou de causalidade linear com a forma de expressão(...). Eis porque é necessário chegar, no próprio agenciamento, a algo que é ainda mais profundo do que essas faces, e que dá conta ao mesmo tempo das duas formas em pressuposição: formas de expressão ou regimes de corpos (sistemas físicos). É o que denominamos máquina abstrata, sendo que esta constitui e conjuga todos os picos de desterritorialização do agenciamento". ${ }^{21}$

Antes de partirmos para o entendimento desta máquina abstrata, outra pergunta deve ser respondida, como o que seriam as formas de conteúdo expressão e matéria - função que Deleuze e Guattari mencionam?

Logo eles exemplificam com o entendimento de Foucault em "Arqueologia do Saber" acerca de "dois tipos de 'multiplicidades', de conteúdo e de expressão". Através de "Vigiar e Punir" ele encontra uma instância que dá conta destes dois conceitos simultaneamente. Tal instância são os agenciamentos de poder que ele descreve - escolas, hospitais, asilos, exército e prisões - mas que correspondem a singularidades, a graus de conteúdo e expressão "em um 'diagrama' abstrato". Tal diagrama abstrato a que Deleuze e Guattari se referem é o Panóptico. Ele comporta, segundo os autores, matéria (multiplicidade humana) e função (o controle de desta multiplicidade) ${ }^{22}$.

Por matéria, eles definem como um plano de consistência, um corpo nãoformado, não-organizado e tudo que escorra sobre ele, ou seja, intensidades. No caso do Panóptico, os presos é que estavam sendo observados e regidos pela influência do diagrama de poder que é estabelecido pela centralidade da torre e disposição perimetral das celas.

\footnotetext{
${ }^{21}$ DELEUZE; GUATTARI, 1995b, p. 98.

${ }^{22}$ Ibid., loc. cit.
} 


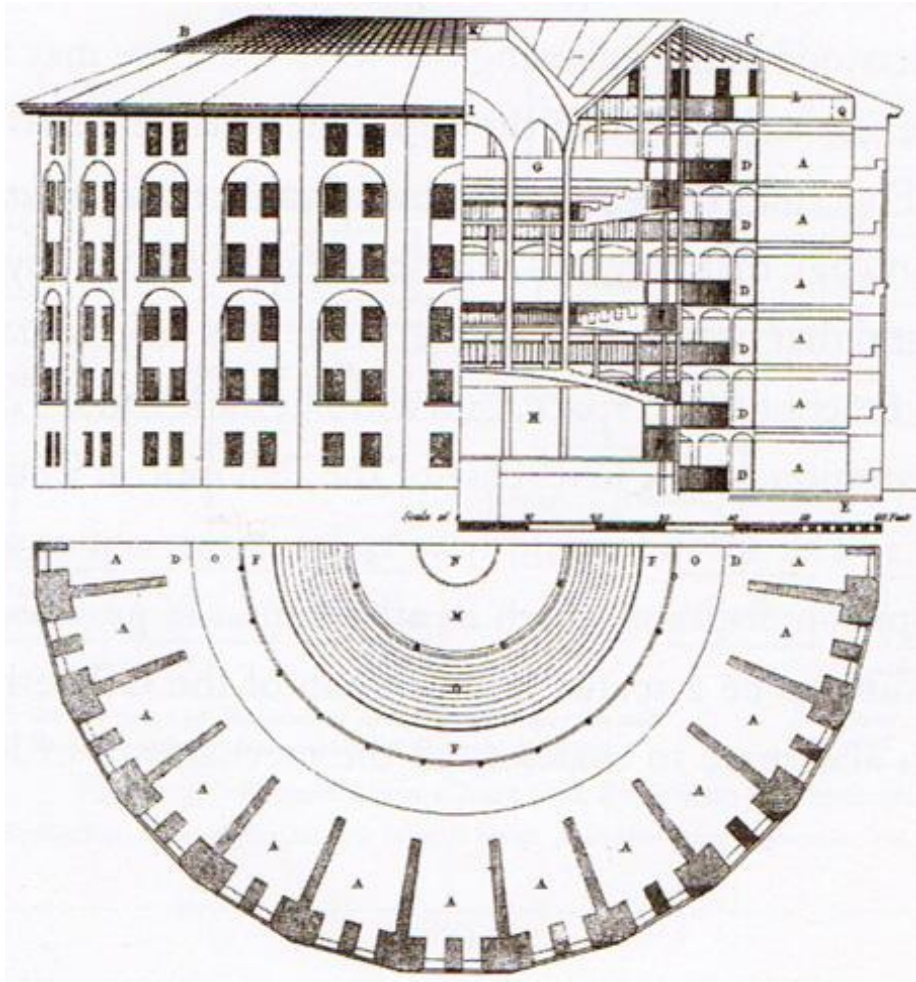

Figura 3.1 Panóptico. Proposta de Bentham como modelo de penitenciária

Vejamos o exemplo a seguir:

"Exprimir é cantar a glória a Deus. Sendo cada estrato um juízo de Deus, não são apenas as plantas e os animais, as orquídeas e as vespas que cantam ou se exprimem, são também os rochedos e até os rios, todas as coisas estratificadas da terra". ${ }^{23}$

Como Deleuze e Guattari explicam, a distinção entre as duas articulações (as plantas e animais como primeira e rochedos e rios como segunda articulação) se dá entre o conteúdo e a expressão, o modo diferente de cantar de cada grupo.

Para eles, o plano de consistência (onde o diagrama opera) é oposto ao que eles chamam de plano de composição, que formaliza a substância e o sujeito. $\mathrm{O}$ plano de consistência, opostamente, opera por hecceidades, modos de individuação que não se constituem pela forma nem por um sujeito. O plano de consistência reúne as hecceidades, os disparates, as multiplicidades. Nunca em unificações, definições ou totalizações, mas por consolidações e consistências. ${ }^{24}$

É neste plano que se inscrevem os acontecimentos, movimentos ${ }^{25}$, os devires, tal como mencionado anteriormente. O mecanismo pelo qual estes devires

\footnotetext{
${ }^{23}$ DELEUZE; GUATTARI, 1995a, p.58.

${ }^{24}$ DELEUZE; GUATTARI, 1997a, p. 222.

${ }^{25}$ Os estudantes de Maio de 68 evitavam o nome de "evento" para julgá-los, preferiam o termo "movimento".
} 
são retirados ou possibilitados, o meio com o qual opera em um agenciamento criando fluxos, linhas, desterritorializações, descodificações, abrem um agenciamento territorializado para outra coisa, é o que Deleuze e Guattari chamam de máquinas abstratas. São abstratas por ignorarem forma e substância, e operarem por "matérias não formadas e funções não formais" 26 .

"Uma máquina abstrata em si não é mais física ou corpórea do que semiótica, ela é diagramática (ignora ainda mais a distinção do artificial e do natural). Opera por matéria, e não por substância; por função, e não por forma. (...) Enquanto a expressão e o conteúdo têm formas distintas e se distinguem realmente, a função tem apenas 'traços', de conteúdo e de expressão, cuja conexão ela assegura: não podemos mesmo mais dizer se é uma partícula ou se é um signo. Um conteúdo-matéria que apresenta tão somente graus de intensidade, de resistência, de condutibilidade, de aquecimento, de alongamento, de velocidade ou de demora; uma expressão-função que apresenta tão somente 'tensores', como em uma escrita matemática, ou antes, musical". ${ }^{27}$

Ainda:

"É então o conteúdo mais desterritorializado e a expressão mais desterritorializada que o diagrama retém, para conjugá-los. E o máximo de desterritorialização vem ora de um traço de conteúdo, ora de um traço de expressão, que será denominado 'desterritorializante' em relação ao outro, mas justamente porque ele o diagramatiza, arrastando-o consigo(...)". ${ }^{28}$

Deste modo uma máquina abstrata é definida por seu diagramatismo. Deleuze e Guattari ainda a diferenciam da tricotomia semiótica peirceana de índice, ícone e símbolo, afirmando que o diagrama não é um signo icônico relacional, mas parece estar em outro posto ${ }^{29}$.

A máquina abstrata, do modo que é explicada em Mil Platôs não é uma infraestrutura, uma Idéia, mas tem um papel piloto:

“Uma máquina abstrata ou diagramática não funciona para representar, mesmo algo de real, mas constrói um real por vir, um novo tipo de realidade". ${ }^{30}$

Um agenciamento, segundo Deleuze e Guattari, "está tanto mais próximo da maquina abstrata viva quanto mais abre e multiplica as conexões". Dizemos máquina abstrata viva no sentido de "máquinas abstratas de consistência", opostas às "máquinas abstratas de estratificação ou às sobrecodificadoras que realizam

\footnotetext{
${ }^{26}$ DELEUZE; GUATTARI, op. cit., p. 227.

${ }^{27}$ DELEUZE; GUATTARI, 1995b, p. 99-100.

${ }^{28}$ Ibid. p. 100.

${ }^{29}$ Cf. op. cit., nota de rodapé.

${ }^{30}$ DELEUZE; GUATTARI, 1995b, loc. cit.
} 
totalizações, homogeneizações, fechamentos tais quais eram submetidos os alunos e operários na França nos anos 60.

A essência da máquina, segundo Guattari ${ }^{31}$ é "relacionada aos processos de desterritorialização de seus elementos, funções e relações de alteridade”. Ela é "autopoética, auto-produtiva e continuamente reproduz seus componentes, diferente de um sistema de input ou output".

O diagrama, para Deleuze e Guattari, faz parte da Pragmática que desenvolvem com o objetivo de estabelecer outra "semiótica" (talvez este termo não seja o mais correto porque não trabalham com signos, mas signos-partículas). Tal dispositivo, o diagrama tem como objeto tomar as formas de expressão e extrair delas signos-partículas que são traços não formados, combináveis. De tal modo, é a definição de máquina abstrata que constrói um real por vir. Devemos fazer uma pausa e reler o que foi escrito. Máquina abstrata e diagrama são dois conceitos diferentes. Deleuze e Guattari os usam de maneira próxima, mas distintas. Uma das etapas da Pragmática dos autores constitui em "fazer o diagrama das máquinas abstratas colocadas em jogo em cada caso, como potencialidades ou como surgimentos efetivos" ${ }^{32}$. Uma máquina abstrata opera diagramaticamente e um diagrama pode ser uma máquina abstrata a partir do momento que ele estabelece novas conexões, desterritorializa elementos ou opere como descodificação em agenciamentos concretos.

De acordo com Ricardo Basbaum ${ }^{33}$ o diagrama, dentro do conceito de "construir um real ainda por vir, um novo tipo de realidade", é colocado em uma posição importante pensado como detentor de uma autonomia estética (assim como de um regime de signos semióticos) e vinculado a processos de transformação. Para Basbaum, o diagrama é traçado como conseqüência do funcionamento de uma máquina abstrata sobre uma matéria, trazendo consigo, neste argumento, uma propriedade maquínica. Ao traçar um diagrama acontece uma operação de desterritorialização e redefinição de coordenadas para além de um sistema de

\footnotetext{
${ }^{31}$ GUATTARI, 1995, passim.

32 DELEUZE; GUATTARI, 1995b, p. 106.

33 BASBAUM, Ricardo. Diagramação e processos de transformação. In CRUZ, Jorge (org). Gilles Delleuze, sentidos e expressões. Rio de Janeiro, Ed. Ciência Moderna:2006 p65-92
} 
signos prévios (essa constitui a abstração absoluta a que Deleuze e Guattari se referem ${ }^{34}$ ).

"[O diagrama] é um dispositivo que indica a ocorrência de um processo especial em um momento específico; o processo implica uma conexão instantânea entre pelo menos duas realidades disjuntivas heterogêneas (matéria/função, enunciados/visibilidades, palavras/imagens [...])" 35 conteúdo/expressão,

Além destas conexões (e por causa delas), o diagrama "é a produção de [um] real com instauração de novas semióticas, isto é, um novo agenciamento compreendendo pensamentos, objetos, gestos". ${ }^{36}$

Esta descrição do conceito de máquina abstrata é vinculada ao conceito de diagrama através de sua leitura do Panóptico por Foucault. Quando menciona "o diagrama, ou a máquina abstrata, é o mapa das relações de força, mapa de densidade" 37 ele fala do panóptico, que neste caso gera (ou é gerado) por um diagrama que também pode ser visto como uma máquina abstrata porque as relações dispostas no diagrama são maquínicas que "passa a cada instante por todos os pontos, 'ou melhor, em toda relação de um ponto a outro'". ${ }^{38}$

Mas apontamos para outro conceito de diagrama trazido por Deleuze em Francis Bacon, a lógica da sensação. Neste livro é feita uma análise do processo de pintura de Bacon, onde Deleuze traz o conceito de diagrama como "o conjunto operatório de manchas e traços irracionais, involuntários, acidentais, automáticos, livres, ao acaso, que são não representativos, não ilustrativos, não narrativos. São traços de sensação". 39

\footnotetext{
${ }^{34}$ Para eles, Chomsky não criou uma máquina abstrata com sua gramática generativa porque não foi suficientemente abstrato. Ele estaria vinculando formas de expressão a conjuntos de universais já definidos que a linguagem supõe, ou seja, sua abstração era limitada ao plano de expressão, não ao plano de conteúdo, como faz uma máquina abstrata plena. Cf. Deleuze e Guattari MP v 2 p 99.

${ }^{35}$ BASBAUM, 2006, p. 85.

${ }^{36}$ Ibid., p. 85-86.

${ }^{37}$ DELEUZE, 2006a. p 46

${ }^{38}$ DELEUZE, 2006a loc. cit.

${ }^{39}$ MACHADO, Roberto. Deleuze, arte e a filosofia. Rio de Janeiro: Jorge Zahar Ed.: 2009
} 

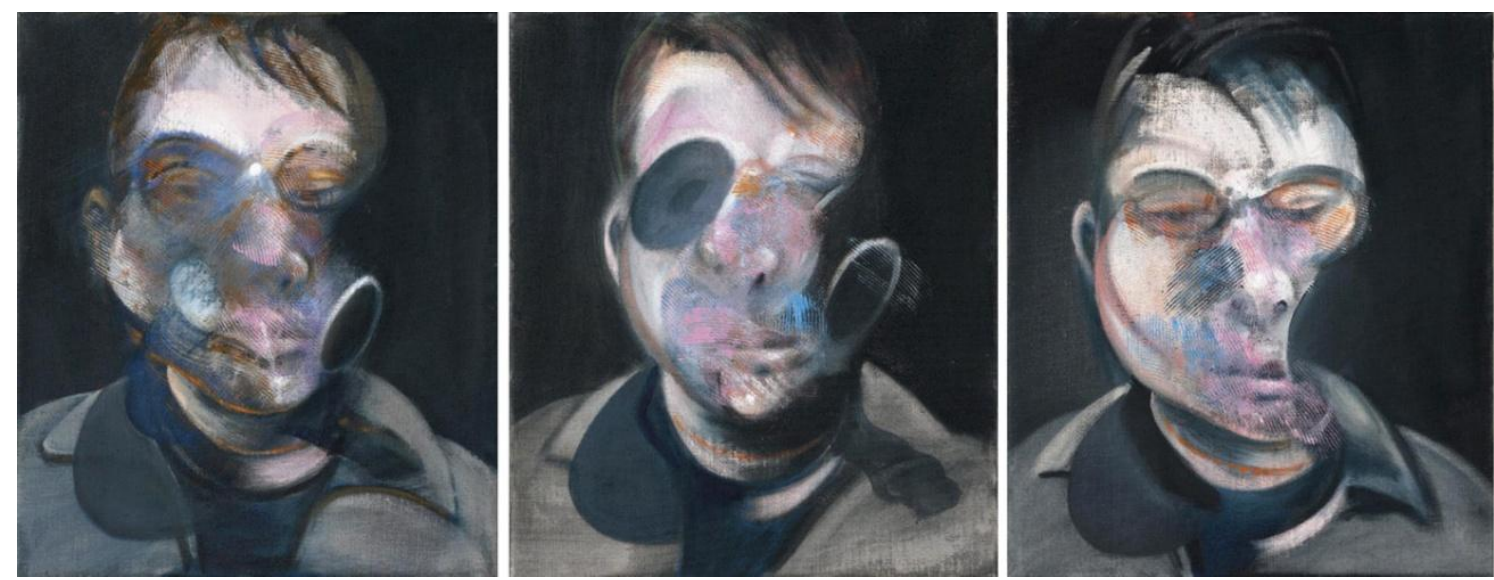

Figura3.2 Três estudos para um auto-retrato. Francis Bacon 1979.

Segundo Machado, ele explica o diagrama como potência manual em que a mão se insubordina e deixa ser guiada pelo olho. Assim, o diagrama não recua o pictural e faz transparecer forças informais distribuídas na tela que se tornam, finalmente picturais. "Se a figura não surgir desse trabalho manual, insubordinado em relação ao olho, é porque o diagrama fracassou em sua função" 40 porque as marcas deixadas podem estragar o quadro ao invés de auxiliar o processo.

"É como o nascimento de outro mundo. Pois essas marcas, esses traços, são irracionais, involuntários, acidentais, livres ao acaso. Eles não são representativos, não ilustrativos, não narrativos. [...] São traços de sensações, mas de sensações confusas". ${ }^{41}$

Bacon afirma ${ }^{42}$, "a função do diagrama é sugerir", introduzir possibilidades, "possibilidades de fato", a pintura é uma matriz de caos, de catástrofes, "mas também um gérmen da ordem". ${ }^{43}$

O diagrama em Bacon é trazido após a execução de algo figural no quadro de modo que rompa com esta figuração, crie linhas de fuga, crie uma "zona de indiscernibilidade entre duas formas", uma deformação que faz com que o pintor crie um discurso próprio com a obra através de forças e partes deformadas, através de forças informais.

\footnotetext{
${ }^{40}$ MACHADO, 2009 p. 241

${ }^{41}$ DELEUZE, 2007, p. 103.

42 lbid., p. 104.

${ }^{43}$ MACHADO, op. cit., p 242.
} 
Tal como Deleuze afirma, a questão é como retirar o pintor da tela, uma vez que ele já se encontra nela. ${ }^{44}$ Saindo da tela ele sai do clichê e para consegui-lo, ele usa de traços, de "marcas manuais ao acaso que the darão esta chance".

O processo de Bacon trabalha com duas figurações. A primeira é tradicionalmente figura, algo está na tela como representação, mas num instante seguinte, os movimentos catastróficos (limpar a tinta, varrer, jogar a tinta, etc.) destituem a imagem desta posição para lançá-la em um momento desorganizado, mas que através de outras interferências do pintor, trazem uma possibilidade impensável anteriormente em direção a uma segunda figuração, sua atualização. Esta figuração final não se assemelha a inicial, daí a fórmula de Bacon: "assemelhar, mas por meios acidentais e não semelhantes". ${ }^{45}$

${ }_{44}^{44}$ DELEUZE, 2007, p.100.

${ }^{45}$ Ibid., p. 101. 
[Análise do conceito de diagrama em

Peter Eisenman] 


\section{CAPÍTULO 4 - O território da escrita de Peter Eisenman}

Podemos dizer que o percurso que Eisenman traça até atingir o momento atual tem início em seu doutorado, quando entra em contato com Colin Rowe em Cambridge. Depois da defesa de seu doutorado em 1963, ele traça um destino teórico que é sustentado pela fundação do Instituto para Arquitetura e Estudos Urbanos em Nova York no ano de 1967. Neste Instituto, junto com Michael Graves, publica a revista Oppositions que acaba se tornando alvo da atenção da crítica arquitetônica da época. Nesta revista, Eisenman publica alguns conceitos e manifestos como "Pós-Funcionalismo" 1.

De acordo com $M_{0}{ }^{2}$, é provavelmente com este contato com Rowe durante seu doutorado que Eisenman desperta a atenção para uma arquitetura moderna que não tenha sido completamente realizada, que não tenha completado a missão que pretendia. Para Eisenman, o fator mais marcante desta falha na realização da arquitetura moderna foi o fato de se preocuparem em excesso com o funcionalismo que ocupou a gestação da arquitetura moderna de modo a distrair os arquitetos de uma arquitetura mais genuína, dentro de seus objetivos originais. Eisenman, então, se dedica a libertar a arquitetura de todas suas amarras e a desdobrá-la de suas contaminações, sejam elas o lugar, a função ou sistemas construtivos. $^{3}$

\footnotetext{
"A mudança desejada pelo espírito moderno não poderia ser apenas uma mudança de estilo, mas uma mudança de substância e, desta maneira, uma mudança de linguagem".4
}

Então a arquitetura poderia, assim como fizeram os cubistas ao liberar a pintura da dependência do conteúdo, ser deslocada de preocupações ditadas pela função, local, técnica ou programa e direcionada apenas a princípios formais que ajudariam a solucionar uma questão. A partir da vontade de descobrir uma nova substância e, portanto, uma nova linguagem da arquitetura, Eisenman se dedica à

\footnotetext{
${ }^{1}$ EISENMAN, 1976.

${ }^{2}$ MONEO, 2004. p. 146.

${ }^{3}$ lbid, p 148.

${ }^{4}$ Ibid, p 148.
} 
lingüística de Chomsky como fundamento para seus primeiros estudos na tentativa de descobrir estruturas, leis ou princípios que regessem a composição da forma da arquitetura.

De acordo com Moneo, é nos estudos de Eisenman sobre Terragni que podemos entender o que ele almejava com suas pesquisas. Moneo cita a seguinte passagem sobre Eisenman:

"O processo de desenvolvimento das formas de Terragni pode ser entendido como uma tentativa de suprimir o objeto ou a leitura da estrutura superficial em favor de uma presença visível da estrutura profunda ou conceitual" 5 .

Eisenman separa as relações sensoriais imediatas do objeto como textura, cor e forma das relações "mais profundas" como sensorialidade, frontalidade, obliqüidade, compressões e alongamentos que seriam percebidas com a mente ${ }^{6}$. Mais tarde Eisenman utiliza o termo interioridade para identificar essas características que estariam dentro de uma imanência na arquitetura e que ele tenta extrair através de seus processos que operam relações entre elementos compositivos da forma, elaborando um raciocínio relacional que mais tarde será chamado de diagramático.

Em um primeiro momento imaginou-se que Eisenman operava sua teoria de diagramas através do conceito de Deleuze e Guattari sobre máquina abstrata, como cita Somol:

\begin{abstract}
"Depois de 1974, em contextos acadêmicos e profissionais, contudo, essa epistemologia do espaço foi rapidamente substituída por um forte pragmatismo, tanto que o alto-moderno diagrama dos nove-quadrados que serviu aos propósitos formais da primeira geração da crítica semiótica foi suplantado por um tipo bastante diverso de diagrama, um diagrama que tem sua forma histórica na discussão do Panopticismo de Michel Foucault e Deleuze". 7
\end{abstract}

Ou ainda:

"O diagrama é a possibilidade do fato, não é o fato em si mesmo".8

Mas o termo "máquina-abstrata" (referência direta ao conceito de Deleuze, como ele definiu o diagrama em seus textos) aparece apenas em publicações muito

\footnotetext{
${ }^{5}$ EISENMAN, 1979, p. 38-39.

${ }_{7}^{6}$ MONEO, 2004, p. 150.

${ }^{7}$ SOMOL, 2007. p 22.

${ }^{8}$ Deleuze, 2007, p. 112.
} 
posteriores a seus projetos, tal como em sua entrevista a Zaera-Polo na revista El Croquis 83 (1997) e em Tracing Eisenman na descrição do projeto Bruges Concert Hall (1998-1999).

Ao mesmo tempo em que afirma sua arquitetura como um processo de desestabilização da forma, como algo que esteja além da semelhança e utilidade e em constante estado de transformação ${ }^{9}$ (o devir da filosofia francesa), Eisenman também afirma que o entendimento do significado do diagrama como uma série de processos que não são mecânicos nem orgânicos, um diagrama de instabilidade, de matéria e fluxos não é aplicável à arquitetura ${ }^{10}$ por três razões principais: a submissão arquitetônica com a metafísica da presença; a condição já motivada do signo em arquitetura e a relação necessária da arquitetura com um tema desejado. Deste modo ele afirma que o mecanismo diagramático que deve ser tomado é o de escrita trazido por Derrida como "a abertura de pura presença". Escrita, tal como Derrida sugere, é uma condição de memória reprimida. Uma repressão da escrita implica em reprimir aquilo que ameace a presença. Assim, aquilo que ameace a presença na arquitetura estará reprimido em sua interioridade (a arquitetura se porta como escrita). Deste modo, Eisenman trabalha com outro conceito de Derrida, o de traço.

Enquanto um desenho de uma planta desenhada é definido, traços emergem e sugerem percursos ao processo.

Tal procedimento é tema deste trabalho, mas, inicialmente, o que devemos ter como leitura paralela a de Eisenman, para entender claramente sua metodologia, são os textos de Chomsky, Saussure, Peirce e Derrida, sendo este último mais representativo nos conceitos do arquiteto após a obra de Cannaregio (1978).

Similarmente, parodiando Derrida ${ }^{11}$, é com conceitos herdados da filosofia que Eisenman opera. Ora, como esses conceitos não são elementos isolados, como são tirados de uma sintaxe, um sistema, cada empréstimo determinado faz vir a si toda a filosofia.

\footnotetext{
${ }^{9}$ EISENMAN, Processes of the Intersticial. in El Croquis 83/1997, p. 21.

${ }^{10}$ Id., 1999 , p. 30.

11 "É com conceitos herdados da metafísica que, por exemplo, Nietzsche, Freud e Heidegger operam. Ora, como esses conceitos não são elementos, átomos, como são tirados duma sintaxe e dum sistema, cada empréstimo faz vir a si toda a metafísica". DERRIDA, 2005, p. 234.
} 
Talvez seja impossível efetuar um mapeamento sistemático e comparativo da filosofia eisenmaniana, (ou será um trabalho para alguém realmente obcecado com isso), uma vez que ele interpreta conceitos da lingüística dentro da arquitetura e os sobrepõe de tal maneira que formam um amálgama conceitual. Existem muitas possibilidades de entendimento da teoria e obra deste arquiteto e por causa disso, Peter David Eisenman, há tanto chamado de "diagramático" faz jus ao termo. Neste trabalho pretendemos abordar o estudo do processo diagramático, mas através de sua evolução temporal, partindo da sua tese de doutorado em 1963 a seus trabalhos recentes.

Normalmente, na arquitetura, os trabalhos teóricos e práticos são visualizados através de um mapeamento de obras e a verificação da relação com suas teorias. Muitos arquitetos permitem esse tipo de ligação, mas no caso de Eisenman, estas conexões são feitas de modo diferente. Não são as teorias que ligam as obras, mas as obras que ligam as teorias. O que deve ser atentado no trabalho de Eisenman é como as teorias se relacionam (se diagramam), como elas se desenvolvem representadas pelos projetos arquitetônicos. $O$ arquiteto parece fazer experimentos teóricos em suas obras que, de acordo com ele, não podem ser analisadas sem levar em consideração a(s) teoria(s) que sustenta $(\mathrm{m})$ o conceito de tais projetos ${ }^{12}$.

Então, para entender sua teoria do diagrama, este capítulo irá mapear as relações entre sua teoria, obras e exterioridades trazidas ao conceito arquitetônico de modo que possamos criar um entendimento sobre seu processo diagramático neste mapeamento.

Eisenman passa por campos de difícil entendimento teórico, como a lingüística de Chomsky, Peirce e Saussure chegando até a filosofia francesa: Foucault, Gilles Deleuze, Félix Guattari e Derrida. ${ }^{13}$

Quando é dito que Eisenman é um arquiteto diagramático não significa apenas que ele usa diagramas em seus projetos, mas que a essência de sua formação como arquiteto também é diagramática. Em vários momentos, ele utiliza

\footnotetext{
${ }^{12}$ Tal como mencionado pelo arquiteto sobre o juízo de suas casas: "É claro que os critérios para julgar estas casas [Casa IV e VI] não podem ser o mesmos daqueles que foram usados até agora como critério de juízo em arquitetura. Tais idéias, como uma 'boa planta' ou a estética clássica, já não podem ser argumentos válidos". ZAERA-POLO, in El Croquis 83/1997, p 10.

${ }_{13}$ Guido Zuliani, em seu texto Evidence of Things Unseen (in DAVIDSON, 2006, p. 319-348) ainda cita Leibniz, Proust, Pynchon e Blanchot.
} 
termos provenientes dos conceitos da filosofia e da lingüística, assim como traz para seu discurso conceitos da antropologia e matemática e até mesmo biologia. Seu discurso arquitetônico é alterado constantemente, como será mostrado neste capítulo. Caso compararmos dois textos de diferentes épocas sobre a mesma obra, perceberemos como um novo discurso descreve o processo de projeto, mas armado com novas visões teóricas. Ainda é vaga a origem do discurso do diagrama em Eisenman, uma vez que poderemos perceber vários modelos de diagramas ao decorrer de sua produção impossibilitando dizer com clareza quando ele começa a usar o termo diagrama para definir teoricamente seu processo, mas podemos ligá-lo a seu contato com a filosofia de Derrida (antes disso Eisenman estava trabalhando em termos sintáticos dentro da lingüística). Poderíamos identificar a aparição clara da filosofia francesa em seu trabalho com o projeto do Parc de La Villete, quando convida Derrida para fazer parte de sua equipe ao elaborar um projeto com fundamento de desconstrução. Este projeto é datado de 1987, porém outro projeto de Eisenman, o IBA Social Housing em Berlin, de 1981-1985, já era tido como um dos representantes da desconstrução na arquitetura.

Pode-se perceber que seu contato com a filosofia francesa se deu a partir da primeira metade da década de 80 e foi provavelmente nela onde iniciava suas leituras de Foucault, Derrida, Deleuze e Guattari, de onde traz à arquitetura o conceito de máquina abstrata, i. e., o diagrama ${ }^{14}$.

Eisenman divide o conceito de duas maneiras, duas ontologias: Uma como um artefato ou mecanismo analítico/explicativo e outra como gerativo/generativo. ${ }^{15}$

Como um artifício analítico, o diagrama é uma forma pós-representacional, uma maneira de explicar e analisar um desenho ou uma planta de edifício. É uma maneira de retirar informação que não está explicitada no projeto. O diagrama atua como mecanismo investigativo.

\footnotetext{
${ }^{14}$ Nos textos selecionados de Eisenman para esta dissertação percebeu-se o termo "máquinaabstrata" primeiramente em sua entrevista dada a Zaera-Polo onde esclarece a diferença entre um projeto maquínico (relativo ao mecanismo da máquina) e outro conceito que seria um maquínico deleuzo-guattariano.

${ }^{15}$ EISENMAN, 1999, p. 27.
} 
Já como gerativo ele tem a capacidade de intervir na formação do projeto relacionando elementos e informações de modo a gerar outras ou expor algo latente ao projeto (que ele dá o nome de interioridade da arquitetura).

Quem dá início a este processo de redescoberta e motivação à investigação de "algo a mais" na arquitetura foi Colin Rowe, antigo professor de Peter Eisenman.

No fim dos anos 50 e início dos anos 60, Colin Rowe havia desenvolvido os termos para uma análise formalista da arquitetura moderna através do estudo de obras de Le Corbusier ${ }^{16}$. Rowe fez a comparação e diferenciação entre a Villa Garches, de Corbusier e a Villa Malcontenta, de Palladio ${ }^{17}$. Ele elabora uma crítica afirmando a repetição palladiana em Corbusier, mas observando que as "cópias", ou repetições que se seguiram "falharam" porque "a aderência às regras talvez tenha falhado" ${ }^{18}$.

Eisenman, em uma viagem com Colin Rowe em 1961 encontrou duas obras de Giuseppe Terragni, a Casa Del Fascio e a Casa Giuliani-Frigeriot de onde desenvolveu suas análises da forma. Ele contribui para o discurso de Rowe ao suspender a análise formal, de modo a colocar à prova o modo como o formalismo americano havia institucionalizado o modernismo pós-guerra.

Os diagramas de Eisenman, em sua tese de doutorado ${ }^{19}$, não tinham a intenção de serem os precursores de seu processo diagramático, mas eles tentavam compreender e distinguir a idéia do formal uma vez que o projeto Terragni eliminava o caráter formalista, como simbólico, e passava a pensar a arquitetura de modo sintático ${ }^{20}$.

A partir dessa percepção que o arquiteto desenvolve o raciocínio em busca de uma sintaxe da arquitetura, algo que precise ser descoberto, mas que depois toma a percepção de uma condição interna na arquitetura separando a visão de um objeto a

\footnotetext{
${ }^{16}$ Cf. ROWE, 1989.

${ }^{17}$ De acordo com Somol (2007, p. 182) podemos perceber a influência do trabalho de Wittkower no trabalho de Rowe, quem localiza dentro do movimento moderno um projeto maneirista-humanista.

${ }^{18}$ Rowe, 1989. p 15-16.

${ }^{19}$ Cf. EISENMAN, 2006.

${ }^{20}$ Eisenman, 1979, p. 38-41, passim.
} 
ser descoberto, uma existência a priori, para um meio pelo qual a arquitetura se desenvolve, sua interioridade.

Seu trabalho matemático inicial toma outro entendimento durante a série de casas projetadas finalizando um procedimento lógico relacional para um seguinte, analógico, tomado a partir de diagramas.

Eisenman diz que seu uso da metodologia do diagrama é uma maneira de não recorrer a um conhecimento acumulado ou a experiência e mais precisamente a intenção do arquiteto-autor.

Em sua citação de Guattari:

\begin{abstract}
"'A essência da máquina está ligada a procedimentos que desterritorializam seus elementos, funções e suas relações com a alteridade'(...) Uma máquina de arquitetura, portanto começará com algumas regras determinadas: gravidade, espaço, ocupação, função. Neste sentido a arquitetura sempre parecerá com arquitetura, e como disse Jacques Derrida, sempre 'significará'. (...) A máquina funciona para descobrir o que até então estava reprimido dentro das condições da arquitetura". ${ }^{21}$.
\end{abstract}

Neste sentido Eisenman usa os diagramas como forma de desterritorializar a arquitetura, de removê-las de um significado a priori. O que Eisenman faz com sua arquitetura é a tentativa de evitar uma repressão da disciplina sobre a obra construída e tentar extrair de dentro da arquitetura seus anseios ocultos e que, agora, podem ser revelados e potencializados por seus diagramas.

Este percurso da busca do diagrama a fim de revelar essa condição interna na arquitetura (ou fazê-la emergir) é trazido neste capítulo em paralelo com sua teoria, de onde faço uma leitura crítica a fim de diagramá-los na relação com sua ferramenta, o diagrama.

${ }^{21}$ EISENMAN, In El Croquis, n. 83/1997. p. 8. 


\subsection{A escrita diagramática}

O interesse de Eisenman por uma metodologia sintática sobre a arquitetura aparece em sua observação de Rudolf Wittkower quando esse analisa as obras de Palladio, as villas Palladianas. Nesta análise Wittkower elabora o que foi chamado de "diagrama dos nove quadrados" como forma de sintetizar o pensamento projetual existente nas villas.
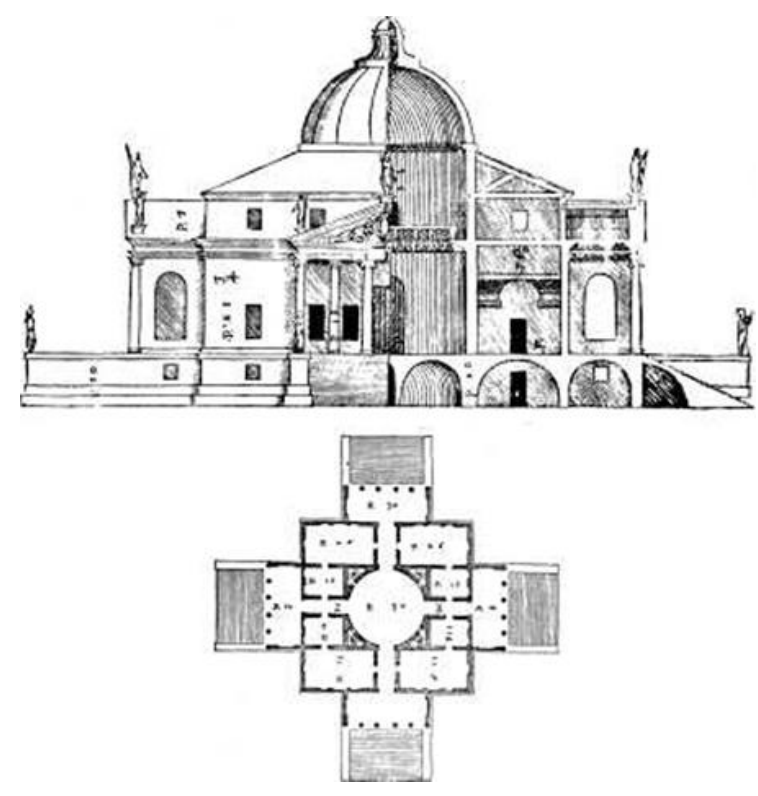

Figura 4.1 Villa Rotonda. (século XVI).

Eisenman diz que os diagramas de Wittkower sobre o trabalho das Villas Palladianas mostram o trabalho de Palladio, mas não como ele trabalhou, i.e. o processo. Palladio tinha em mente um esquema geométrico que foi transferido para o projeto de modo implícito e a análise de Wittkower feita sobre as villas explicita este esquema. Estes diagramas de Wittkower são uma maneira de mostrar este esquema escondido dentro do projeto.

A partir destes estudos, Eisenman introduz uma divisão do termo representação em dois graus ${ }^{22}$ : As representações de primeiro grau seriam as plantas e cortes do objeto, ou seja, registros gráficos que podem elucidar ou nos dar

${ }^{22}$ EISENMAN, 1999, p.41-42. 
a idéia do objeto, como uma fotografia, uma perspectiva ou uma elevação (que Peirce definiria como um signo icônico, a imagem).

Já o conceito de diagrama explicativo são representações de segundo grau como, por exemplo, os desenhos de Wittkower sobre Palladio. Eles são abstrações dos edifícios analisados (as villas). Estes desenhos de Wittkower não indicavam o ato projetual, como um croqui o faz ou representa. Eles possuíam um nível de crítica sobre as plantas analisadas.

De acordo com Eisenman, estes diagramas explicativos - representações de segundo grau - podem ser considerados diagramáticos uma vez que envolvem certo nível de criticalidade, uma remoção ou destituição dos fatos do objeto.

"[...] tipo direciona à abstração; ele o faz de um modo que reduz o modelo, a cópia, ou o original. O diagrama, por outro lado, contém mais que o modelo. O tipo e o diagrama são duas condições diferentes de abstração: tipo, a abstração de uma redução para uma normalização, e o diagrama, a abstração que pode gerar algo a mais que a coisa em si, e deste modo superar a normalização". ${ }^{23}$

Dentro deste conceito ele nos traz a condição de presentness como uma condição do diagrama, diferente do tipo, de significar além da obra. O tipo, uma abstração, reduz toda carga significante para uma padronalização enquanto o diagrama, segundo Eisenman, traz essa qualidade do objeto de ser instrumento crítico além de seu tempo.

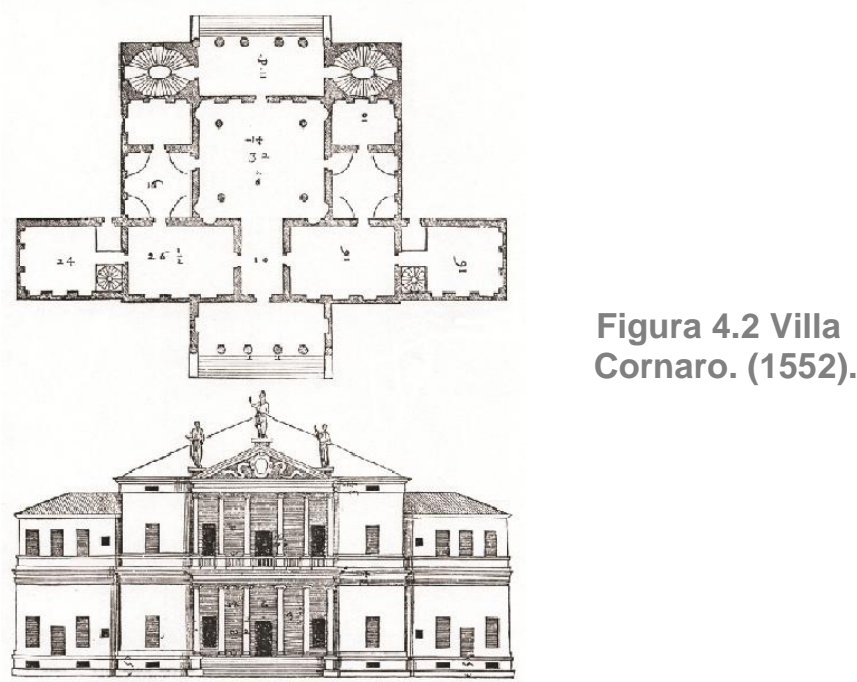

${ }^{23}$ EISENMAN, 1999. p. 42. 
Outro exemplo sobre estas representações de segundo grau pode ser achado em outro momento do texto de Eisenman. Ele cita o caso dos desenhos de Villard d'Honnecourt que usou matrizes geométricas para gerar figuras de naturais, de pessoas e animais. Na figura 4.3 aparecem exemplos onde bases geométricas préestabelecidas fornecem a informação para a síntese da imagem. Observe o caso da águia formada por um pentágono. Essas imagens construídas partem de uma base geométrica formada por linhas - curvas ou retas. Tais linhas estabelecem legivelmente uma relação de proporção entre os elementos componentes da forma real. Estes estudos de proporção não diferem dos executados por Wittkower ao estudar a composição das villas Palladianas.
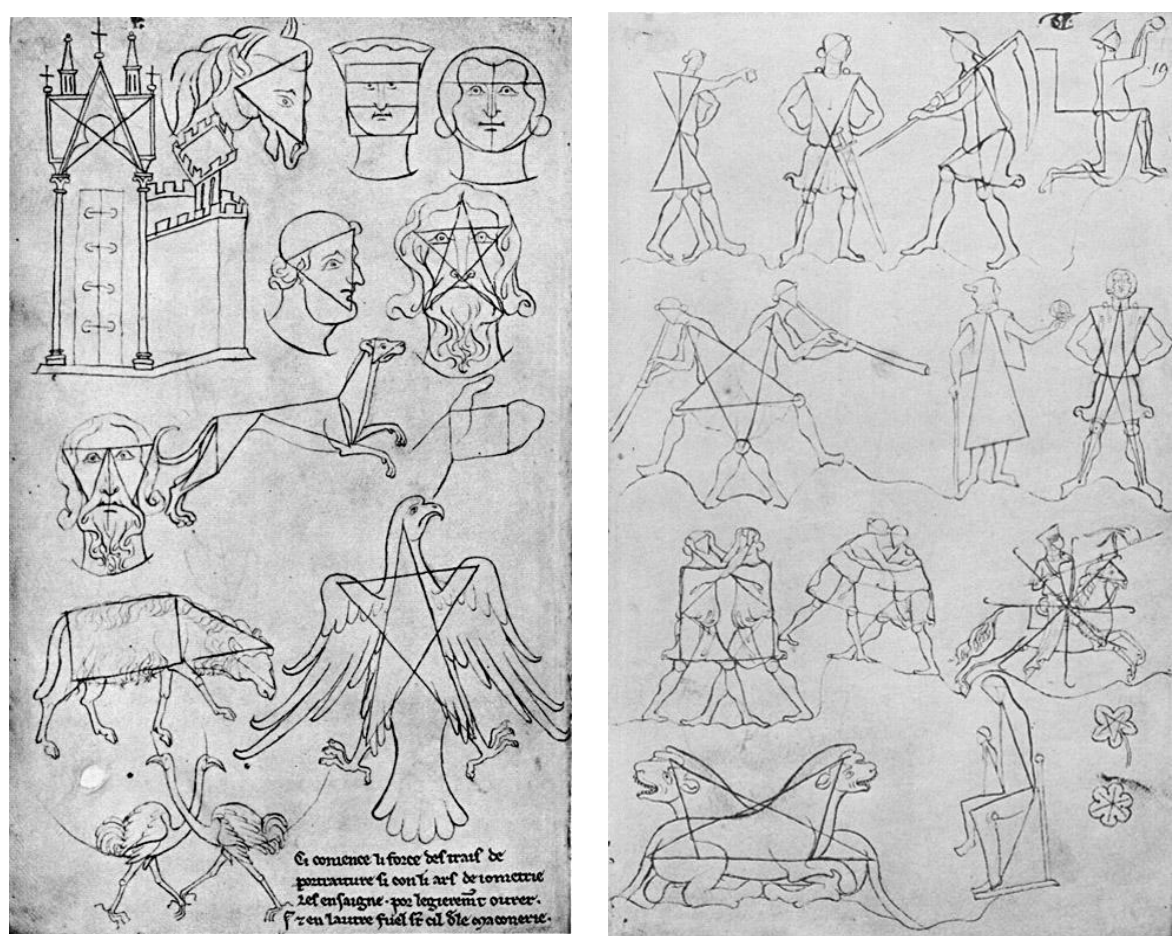

Figura 4.3 Desenhos de Villard d'Hounnecourt.

"Enquanto os diagramas de Wittkower e Rowe essencialmente confiavam numa análise do formal como uma condição estável e a priori, meus diagramas continham as sementes de algo a mais: eles propunham a possível evidência da interioridade formal da arquitetura para problematizar o conceitual, a crítica e talvez à diagramação de uma instabilidade préexistente na sua interioridade. Esta preocupação tem ocupado muito do trabalho que se seguiu. Enquanto estava claro pra mim, naquele tempo que existia uma diferença entre os diagramas de Rowe e Wittkower e nos seus predecessores Heinrich Wölfflin e Paul Frankl, assim como outros diagramas contemporâneos como os diagramas de bolhas da Bauhaus, eu não estava tão consciente da real diferença entre meu trabalho e de Rowe como estou hoje". ${ }^{24}$

${ }^{24}$ EISENMAN, 1999, p 48-49. 
"Claramente, Rowe e Wittkower estavam envolvidos no que poderia ser chamado de articulação de princípios formais em arquitetura; o trabalho deles é o ponto inicial para meu uso do diagrama em uma re-examinação do formal. Neste contexto, função, estética tradicional, preocupações sociais, e metáforas de máquinas, para mim sempre foram pálidas justificações para um expressionismo faça-o-que-quiser". ${ }^{25}$

Segundo seu raciocínio de representações de segundo grau Eisenman estuda a obra de Terragni de acordo com os conceitos lingüísticos de Chomsky na tentativa de observar um princípio gerador daquela arquitetura que, à sua visão, era elaborada segundo princípios compositivos não vinculados a um formalismo como desenvolvido no modernismo, mas era, sobretudo, um projeto regrado por uma composição lógica-matemática, derivável de seus elementos.

Tal estudo gera em Eisenman a imersão no conceito de gramática generativa de Chomsky que passa a ser usado em seus projetos na tentativa da busca de uma "condição interior" da arquitetura.

"A procura de Eisenman pela 'interioridade' da arquitetura não é nem o
desenvolvimento de formas baseadas em conhecimento acumulado, nem a
procura por uma disciplina que permita corporificar paradigmas emergentes
(...) é um processo engenhado para gerar emergências e afiliações
acidentais, revelar potenciais latentes ao contrário de conhecer os
requerimentos de uma demanda emergente". ${ }^{26}$

Ele afirma que seus dois projetos iniciais de casas não estavam tão focados na questão de revelar a interioridade da arquitetura, mas na tentativa de criá-la, retratar sua lógica análoga, através do "agenciamento do diagrama". Seu processo estava focado em um modelo de trabalho lingüístico ao contrário de um arquiteturalhistórico ${ }^{27}$ que foi desenvolvido a partir de 1978.

O que Eisenman chama de "interioridade" aparentemente é confuso, mas no texto da revista Casabella de $1974^{28}$ podemos identificar um conjunto de entendimentos que nos remete ao conceito criado algum tempo depois.

"Existem quatro aspectos em meu trabalho: eles representam atividades
paralelas mais que seqüenciais. Um é analítico; seu contexto é
essencialmente histórico. Ele é concentrado em dois períodos: o trabalho
Renascentista de Palladio, Vignola, Scamozzi, Giulio Romano, etc.; e o
movimento moderno, (...) Le Corbusier e Giuseppe Terragni. A análise é
concebida na correspondência no trabalho do passado entre forma e idéias,

${ }^{25}$ EISENMAN, 1999, p. 49.

${ }^{26}$ ZAERA-POLO, In El Croquis, n. 83/1997. p. 52.

${ }^{27}$ Op. cit., p. 53-54.

${ }^{28}$ Cardboard Architecture, castelli di carte. in: Casabella nํ386, fev. 1974 p 17-29 
a fim de definir a natureza destas correspondências; e a partir disso extrair o que pode ser achado nestas correspondências.

Um segundo aspecto do meu trabalho se refere ao desenvolvimento de uma teoria de Arquitetura Conceitual. Ele é concebido como a diferença entre a percepção da realidade física e a concepção da realidade física". ${ }^{2 \mathfrak{9}}$

Neste texto ele menciona que antigamente as interpretações das implicações do espaço, relacionadas ao que poderia chamar de condições formais ou qualidades, eram ainda muito imprecisas e não estavam formuladas em nenhuma teoria de projeto que poderia usá-las de modo mais lógico e racional. [grifo meu] Neste sentido a Arquitetura Conceitual traria este tema à tona a fim de ser estudado embasando-se nas relações de uma estrutura formal que estudaria a relação entre os objetos, mais que o objeto em si.

\begin{abstract}
"Enquanto a arquitetura de Corbusier permanece comprometida com a criação do significado através da iconografia, da semântica do objeto, Eisenman defende que a obra de Terragni está preocupada em revelar a sintaxe da linguagem arquitetônica. Esta mudança representa um distanciamento das preocupações com as qualidades perceptuais-estéticas do objeto, em direção a uma tentativa de demarcar as relações conceituais que estruturam e possibilitam qualquer (e todo) arranjo formal particular. Além disso, considera que a obra de Terragni demarca a relação entre "estrutura de superfície" e "estrutura profunda", através de métodos transformacionais, que Eisenman procura revelar por uma série de diagramas axonométricos e projeções.
\end{abstract}

Eisenman menciona que este sistema teria dois aspectos: "estruturas profundas duplas" e "operações transformacionais". Por estruturas profundas duplas, Eisenman afirma que é um tipo de estrutura revelada pela análise histórica e pelo estudo de outras disciplinas que estejam preocupadas com comunicação.

Ele afirma que considerar a existência e procurar por esta estrutura formal e relacional no (do) espaço é criar um novo quadro conceitual para o design e para o entendimento de nosso ambiente de modo que "eles se tornem capazes de aceitar um novo e amplo número de sentidos metafóricos e iconográficos ${ }^{30 "}$.

\footnotetext{
29 "There are four aspects of my work: they represent parallel rather than sequential activities. One is analytic; its context is essentially historical. It is concentrated in two periods: the Renaissance work of Palladio, Vignola, Scamozzi, Giulio Romano, etc.; and the modern movement, (...) Le Corbusier and Giuseppe Terragni. The analysis is concerned with the correspondence in past work between form and ideas, to define the nature of these correspondences; and from this extract what which might be found in these correspondences.

A second aspect of my work concerns the development of a theory of Conceptual Architecture. It is concerned with the difference between the perception of physical reality and the conception of physical reality." EISENMAN, 1974, p. 17.

30 lbid., p.24.
} 
Eisenman fala de sua Cardboard Architecture ${ }^{31}$ como um conjunto teóricoprático onde existe um processo de realimentação da teoria, uma dialética, como ele mesmo diz. A teoria é aplicada na prática e esta retorna à teoria. Observando os textos de Eisenman quando se refere a estas estruturas profundas na arquitetura, automaticamente nos remetemos àquele que desenvolveu este conceito anos antes e que foi mentor de Eisenman, Noam Chomsky, que em 1957 lança o livro Syntatic Structures e funda sua gramática gerativa, também conhecida como gramática transformacional.

Chomsky diz que uma língua possui três elementos básicos, sua sintaxe como os elementos, palavras se dispõe; sua fonética - a representação falada, imagem acústica da sintática; e a semântica - que interpreta a imagem acústica. Ele defendia a idéia de que em uma oração existem dois elementos, uma estrutura profunda e uma superficial. A estrutura profunda, latente, encerra o conteúdo semântico da frase enquanto a estrutura superficial representa a forma como aparenta a oração. Segundo Chomsky, deveria haver alguma similaridade entre diferentes estruturas profundas de diferentes línguas e que estas estruturas deveriam revelar propriedades comuns a todas as línguas, mas estavam escondidas sobre a estrutura superficial.

Uma criança não repete as expressões que ouve dos adultos, mas usa a estrutura de composição como um jogo de elementos finitos nestas palavras para poder criar as frases a serem usadas infinitamente. Chomsky defende a idéia de que na composição de elementos finitos, podemos elaborar enunciados infinitos. Para entender melhor a questão de estrutura profunda e superficial, lemos o exemplo:

$$
\mathrm{Neg}+\mathrm{D}+\mathrm{N}+(\mathrm{Asp}+\mathrm{T})+\mathrm{V}+\mathrm{D}+\mathrm{N}
$$

Esta expressão, este componente categorial ${ }^{32}$, define regras de composição e de relação entre os símbolos da seguinte forma:

\footnotetext{
${ }^{31}$ Através da explicação dada pelo autor na revista Casabella número 386, poderíamos traduzir como Arquitetura de Papelão.

${ }^{32}$ Cf. DUBOIS, 1997.
} 


$$
\begin{aligned}
& \text { Neg = negação } \\
& \text { Asp = aspecto ('não acabado') } \\
& D=\text { determinante } \\
& V=\text { verbo } \\
& T=\text { tempo (passado) } \\
& N=\text { nome }
\end{aligned}
$$

Se substituirmos os símbolos por palavras, teremos:

$$
N a ̃ o+o+p a i+(i a)+l e r+o+j o r n a l
$$

Esta é a estrutura profunda anunciada por Chomsky. A estrutura superficial seria passar este mesmo sistema por transformações que após a interpretação do componente fonético se tornaria:

\section{O pai não lia o jornal.}

Dentro deste raciocínio Eisenman menciona que a Arquitetura de Papelão, através da análise de séries de operações transformacionais poderia revelar regras de estruturas sintáticas (ou, na gramática gerativa, o que seria o componente categorial) que geram outras estruturas formais. Mas além de apenas reformular a interpretação do sistema, sua estrutura superficial, Eisenman queria atingir o sentido, a semântica, a estrutura profunda.

Mas a percepção, o entendimento desta intenção não poderia ser dada apenas pelas qualidades do usuário, seus conhecimentos culturais e seu entendimento do ambiente, mas ela deveria surgir da forma, da arquitetura.

Não se tratava de esperar um "bom" espectador (ou uma "boa leitura"), mas de fazer aparecer uma ordem estrutural pouco consciente que:

"(..) se entendida, poderia trazer a arquitetura a um ponto onde a forma
física poderia ser usada como uma marca a fim de produzir uma nova
imagem mental do ambiente diferente do que estava sendo visto. A
estrutura profunda, quando combinada com a realidade física tem a
capacidade (...) de tornar possível um novo nível de informação". ${ }^{33}$

Para fazer essa ordem estrutural aparecer, ela deveria aproximar-se de um ambiente completamente formalizado (as casas iniciais eram geradas a partir de

\footnotetext{
33 "[...] if understood might bring architecture to a point where the physical form might be used as a marking to produce, as it were, a new mental image of an environment different from that which we are actually seeing. The deep structure when it is structured in a perceptible physical reality, has the potential [...] to make available a new level of information". EISENMAN, 1974, p.24.
} 
cubos platônicos, uma forma pura, sem significância) para que os significados tradicionais que ela possuía fossem perdidos e, deste modo, se tornar veículo de nova informação, tanto que Eisenman, nesta revista mencionada, publica imagens das Casa II e IV afirmando que são os dois trabalhos mais significativos nesta metodologia, mas avisa que não seguiriam textos explicando os projetos na tentativa de apresentar, de forma visual as idéias mencionadas no texto.

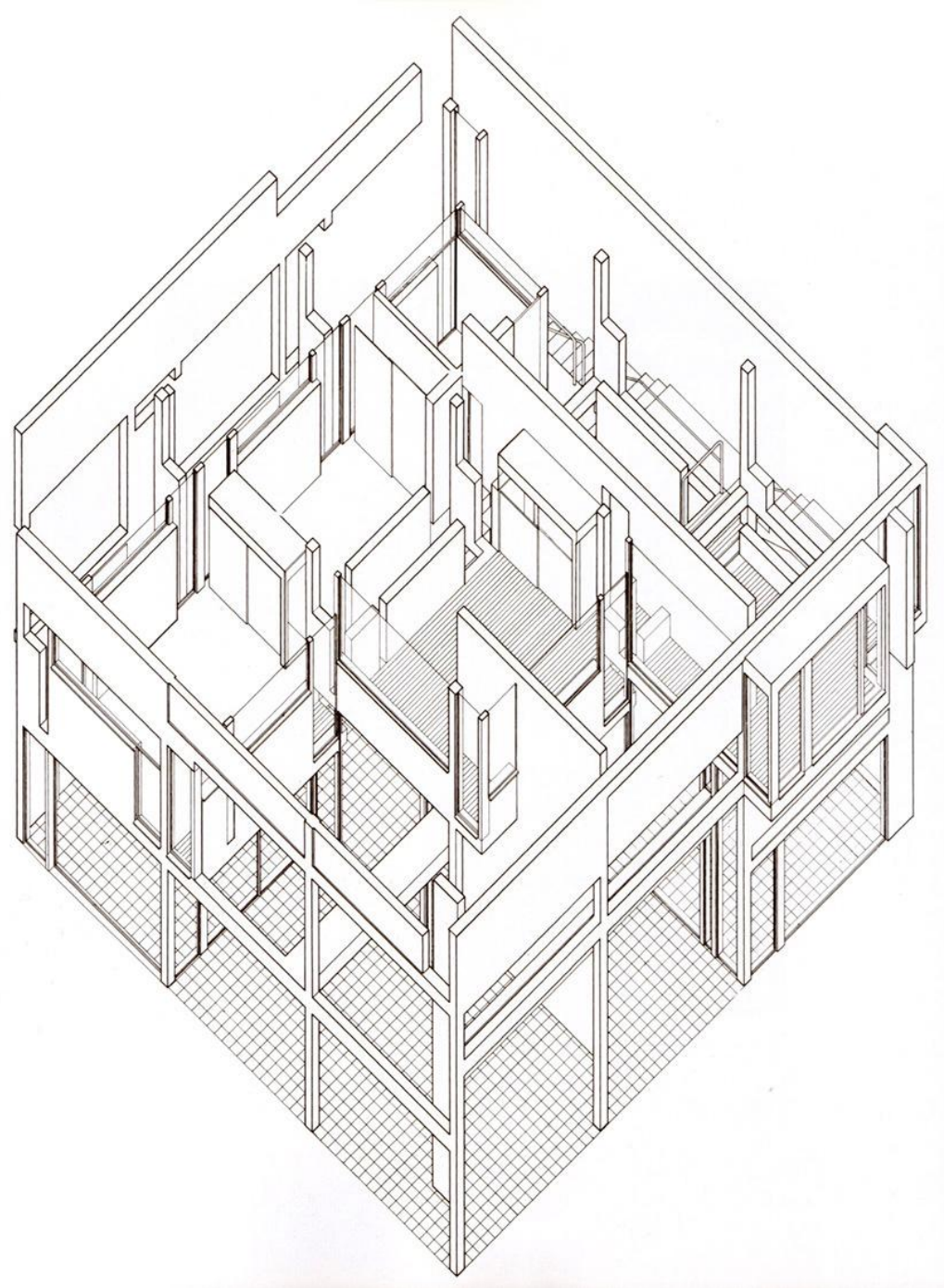

Figura 4.4 Casa II 


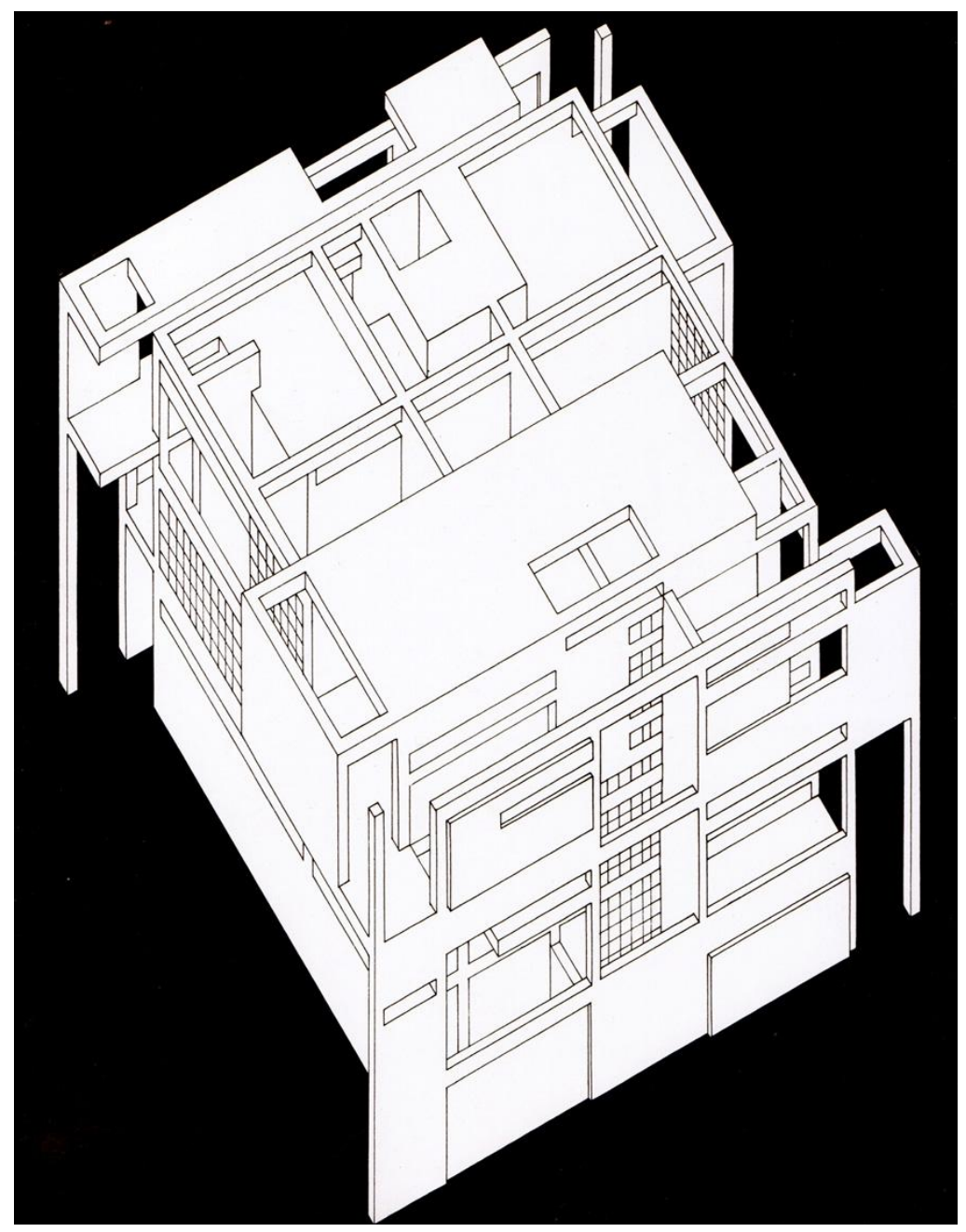

Figura4.5 Casa IV

Mas essa atitude da forma, rompendo e criando novos entendimentos, novas informações, parte de uma nova compreensão da forma que inicialmente deve ser considerada "potencialmente separável" de sua percepção atual e, em segundo lugar, deve ser considerada como capaz de mudar ou ampliar o "nível de consciência" porque propõe uma crítica à condição atual da arquitetura - como, por exemplo, o que deve ser considerado uma "casa".

A necessidade de superar a materialidade da arquitetura, de questionar esta estrutura profunda, de acordo com Eisenman faz parte da natureza singular da interioridade arquitetônica. Segundo Eisenman ${ }^{34}$, é na Casa IV, de 1971, que ele executa seu primeiro projeto completamente diagramático, onde o diagrama não é apenas um meio de explicar o que ocorre, mas de ocorrer.

A percepção da ausência ou existência de paredes durante o processo foi percebida através da ocorrência do fato indicado por uma das imagens realizadas.

\footnotetext{
${ }^{34}$ EISENMAN, 1999, p 69.
} 
Quando fala sobre o diagrama da Casa IV, Eisenman por vezes parece mencionar o mecanismo no qual os volumes, os cubos são relacionados, mas na verdade está se referindo à imagem, a figura que mostra o movimento dos cubos. $\mathrm{Na}$ descrição da Casa IV ele não menciona apenas um diagrama, tal como uma entidade implícita ou inerente ao processo, mas diagramas ${ }^{35}$ e desenhos. Neste sentido, parece-nos que está se referindo ao desenho correspondente a cada momento da geração da casa.

Como a Casa IV foi gerada através de regras embutidas em um "diagrama" inicial que, através do movimento e relacionamento entre os objetos, as formas, cria um conjunto de quadros que ele chama de filme.

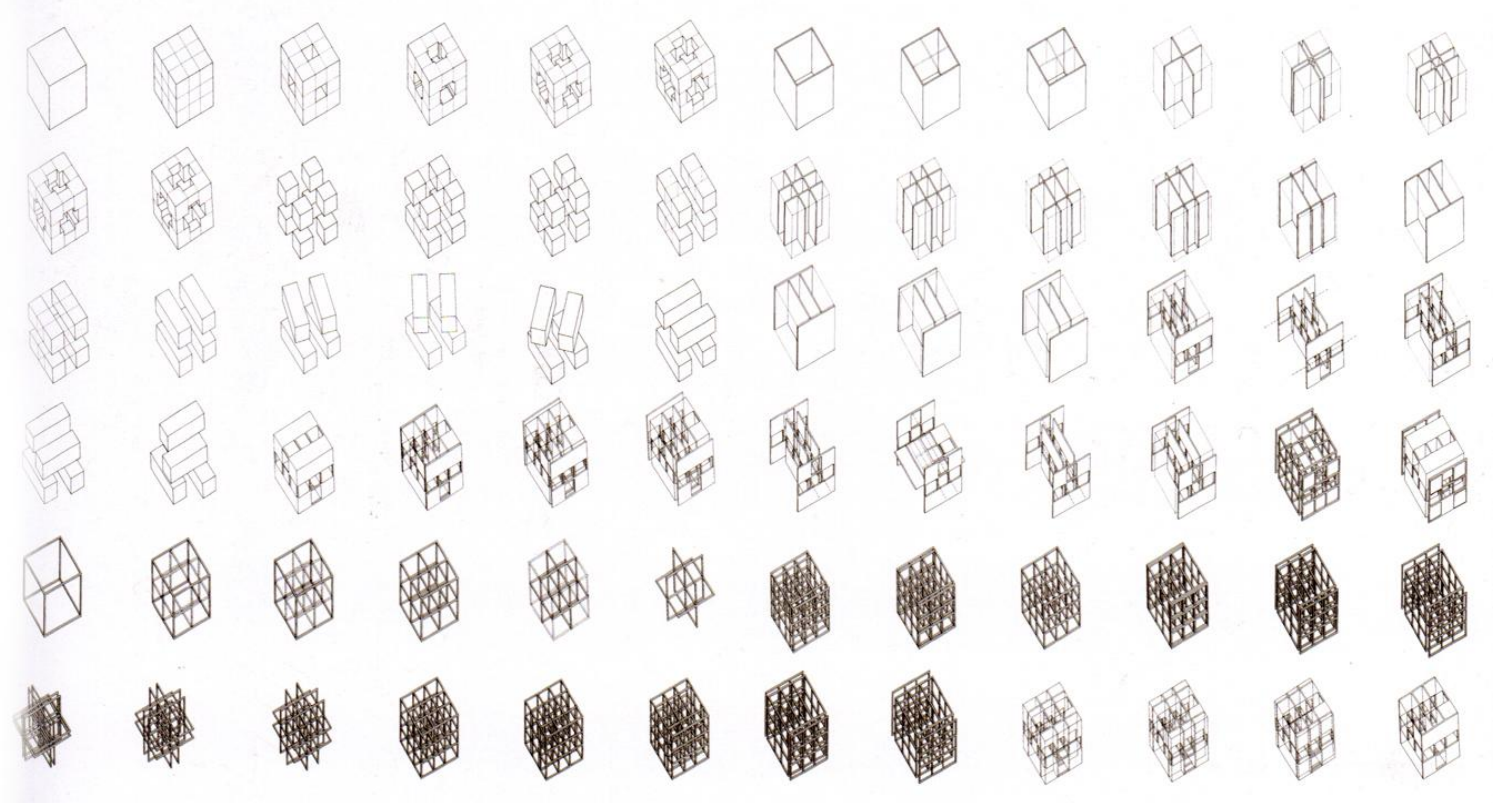

Figura 4.6 Casa IV

Mas, diferente de um filme normal onde os quadros são mostrados em uma rápida seqüencia, aqui as imagens não foram seqüenciadas nem foram deixadas imediatamente próximas umas das outras para evitar que houvesse um entendimento lógico linear e a criação de uma seqüencia que, segundo Eisenman, a especulação de uma ordem em um ambiente caótico é um procedimento natural ao ser humano. O processo de diagramação é necessário para reduzir esta tendência porque "quando os diagramas são dispostos para serem vistos de apenas uma

${ }^{35}$ EISENMAN, 1999, p. 74, 76. 
maneira, eles podem ser entendidos como uma narrativa". ${ }^{36}$ Ora, vemos aqui a emergência do conceito de "texto-duplo" de Derrida. O livro é um texto com uma narrativa a ser seguida e obedecida, mas que um texto duplo (dois textos paralelos ou sobrepostos na mesma página) poderia dissolver.

Assim, Eisenman cria, a partir da Casa IV, o processo que chama de diagramático, mas com o nome de decomposição. ${ }^{37}$

Com essa nova idéia, não seria mais necessário entender a interioridade da arquitetura como um cubo, um cubo duplo ou meio cubo e transformá-los, mas ao invés de começar de uma forma a priori, ele começa de uma condição a priori que seria a percepção de um estado de complexidade. O que ele buscaria agora seria uma "palpabilidade" que não deveria ser entendida como uma origem deste estado complexo, mas uma base para o pensamento que permita fugir do estado de caos. Assim o diagrama não mais evidencia uma origem de onde tudo parte, mas deve conter uma matéria não formada (unformed matter) que coloca o material em suspensão, numa condição congelada no tempo e no espaço a fim de alterá-lo. Interioridade, então, não seria mais conceituada como formada, mas de fato, vista como uma condição bem próxima de uma questão complexa ${ }^{38}$.

A interioridade que antes era vista como possuidora de uma origem definida, parte a ser concebida como uma dupla origem. Se as casas iniciais partiam de cubos, esta parte tanto de um cubo como de uma forma em "L".

A interioridade sugerida na Casa $X$ não poderia ser algo estável e já conhecida. Porque não admitia uma única origem como pensado nos projetos anteriores.

Eisenman afirma que a partir do momento que desenvolve a idéia da interioridade, quando ela passa a se tornar uma preocupação constante e diferente no seu trabalho, ela remete a outro tipo de metodologia que usa o(s) diagrama(s) não mais como uma narrativa, mas como processo construtivo, generativo. Ora, se existe uma alteração da linguagem projetual, se o ferramental é alterado, espera-se

\footnotetext{
36 "When the diagrams were arranged to be seen in a single view, they could be understood as a narrative". EISENMAN, 1999. p. 75.

${ }^{37}$ Ibid., p. 81.

${ }^{38}$ Ibid., p. 82.
} 
que o processo e o produto possam ser alterados. Um novo entendimento emerge, neste caso, através dos diagramas generativos onde acontece a alteração da relação entre sujeito e autor, uma dissolução da autoridade do arquiteto sobre o projeto de arquitetura.

Apesar de terem sido identificados através de sua percepção de um novo meio de pesquisa sobre a interioridade, os diagramas se mostraram como um mecanismo que possibilitou duas outras percepções sobre o tema: a interioridade não uma é uma condição a priori e a arquitetura não é mera transformação geométrica, "paredes têm espessura e espaço tem densidade" 39.

Neste momento acontece uma alteração significativa no entendimento de Eisenman e toda sua teoria. Ele parte de uma questão inicial de que, se a arquitetura não é meramente uma transformação geométrica, ou seja, se uma geometria não depende de um diagrama ou alguma transformação formal para se tornar arquitetura, então o valor depositado nela sob a condição da existência de interioridade é incerto. A alteração promovida pelos diagramas no trabalho com geometria euclidiana ou topológica (Casas VI, El even Odd, Fin D’Ou T Hou S) nada faz além deslocar o valor dado à geometria euclidiana sem realmente deslocá-la em sua essência. A interioridade poderia estar numa condição (ao contrário de estar presente na forma) instável. Se a interioridade é instável na arquitetura, existiriam outros processos além dos transformativos (que se baseavam na alteração de uma forma) a fim de revelar esta interioridade?

A primeira resposta achada foi outro processo diagramático iniciado neste momento, o de decomposição, realizado na Casa X e na El Even Odd.

Tal processo sugeria que a interioridade da arquitetura poderia ser vista como um fenômeno complexo do qual outra complexidade menor, mais simples, poderia ser destilada. Assim, interioridade não necessariamente seria vista com pura, estável ou derivada de uma geometria. Mas mesmo assim Eisenman percebe que a forma, seu foco como objeto de sua pesquisa anterior, na verdade, desfocava sua busca porque a arquitetura sempre está baseada em geometria e vinculada a um universo formal que a materializa.

${ }^{39}$ EISENMAN, 1999. p. 170. 
A hipótese de Eisenman pára no pensamento que elimina a forma como variável, como grade que o impede de buscar a interioridade. Assim, como meio de avançar sua pesquisa sem passar pelo filtro da forma, ou seja, evitar a materialização de algum valor, ele faz uso dos diagramas de exterioridade.

Sua teoria é que, para evitar esta materialização de valores, um elemento externo deve ser trazido - outra imagem conceitual, ou outro diagrama - e que não esteja baseado em geometria, porém distanciado e ao mesmo tempo relacionado a uma interioridade, mas sem defini-la.

Os diagramas anteriores, quando trazidos à arquitetura poderiam trazer uma materialização (motivação) junto deles. Eles seriam, como Eisenman diz, "diagramas motivados" ${ }^{40}$

Então ele traz ao processo textos externos, diagramas "aparentemente aleatórios ou arbitrários", a fim de evitar a "imanência da materialização arquitetônica ou a motivação de seus signos", ou seja, diagramas arquitetonicamente imotivados.

Como representação dessa exterioridade Eisenman cita dois projetos iniciais, o de Cannaregio e a Casa 11a.

A prefeitura de Veneza convoca um concurso para o projeto de Cannaregio, o maio espaço público na cidade. Neste projeto, Eisenman usa uma malha característica do sistema estrutural do projeto do Hospital de Veneza (1940) de Le Corbusier como uma projeção sobre o terreno da praça com o intuito de marcar os nós correspondentes ao projeto registrando, desta forma, uma anterioridade singular neste terreno.

\footnotetext{
${ }^{40}$ Aqui Eisenman retoma a semiologia saussureana quando menciona motivação. Saussure traz o conceito de signo motivado para definir o signo que não possui referência com seu objeto, "ele é arbitrário em relação ao significado com o qual não tem nenhum laço natural na realidade". SAUSSURE, 2006, p 81-83.
} 


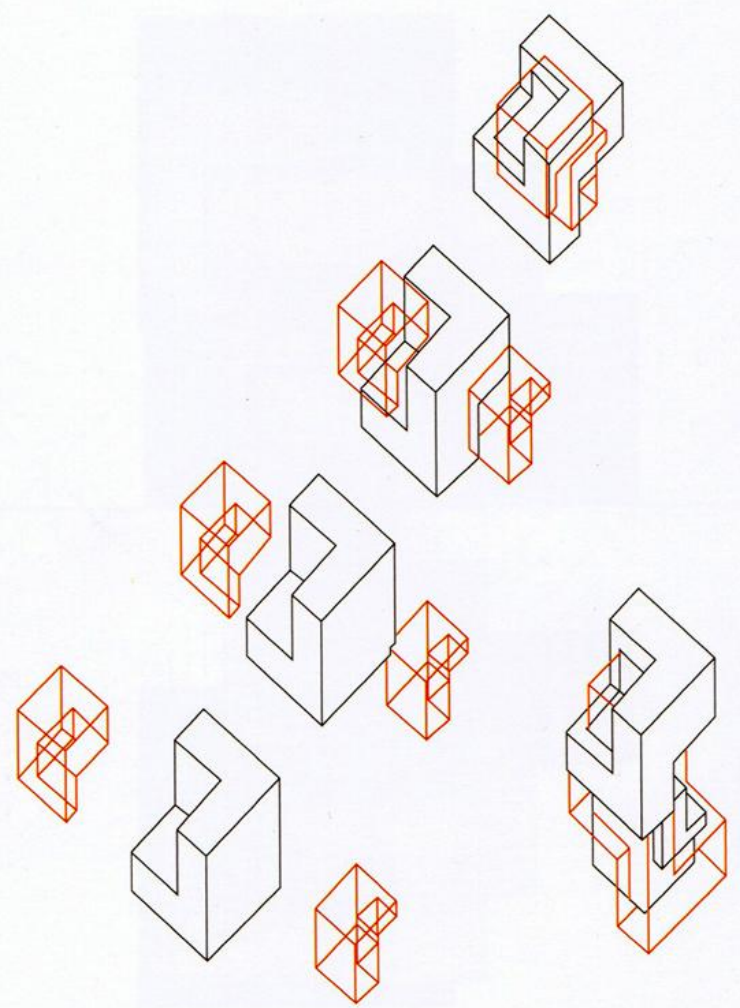

Figura 4. 7

Casa 11a

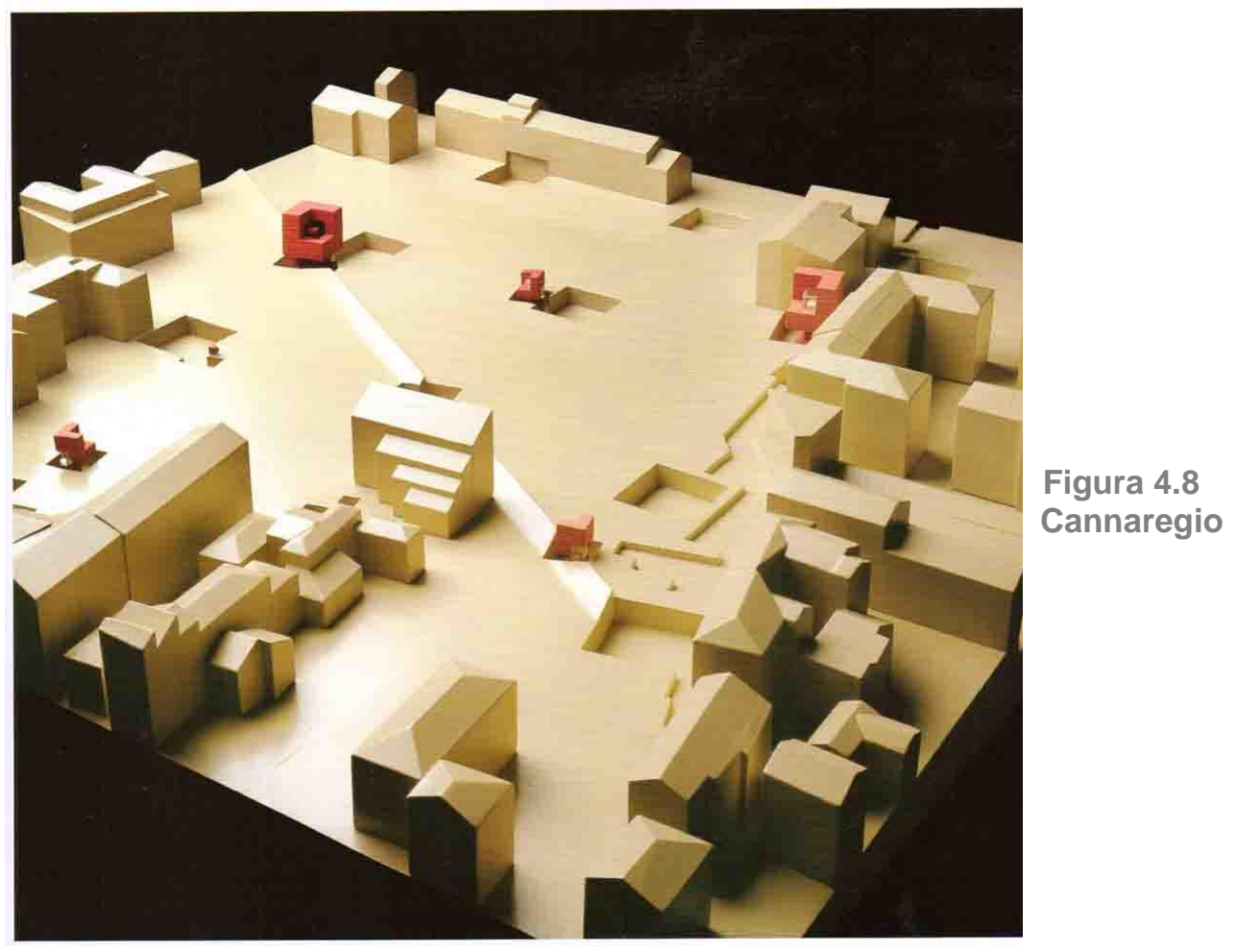


Eisenman diz trabalhar com o terreno não como um plano, mas uma superfície topológica, uma vez que o terreno, tema característico da arquitetura, deveria ser questionado, assim como ele questionou a estabilidade da interioridade da arquitetura.

Propositalmente ele pensa o terreno não como um plano estático, puro e sobre o qual a arquitetura se constrói, mas cria vazios, escavações orientadas pelo projeto de Le Corbusier que acabam por criar a idéia de uma superfície ao invés de um plano euclidiano devido às interferências, furos neste plano bi-dimensional criando a impressão de rupturas, e um espaço tridimensional, aberto, rompido e elevado ao grau de topologia.

No espaço da praça são dispostas versões de diferentes escalas da Casa 11a que são inseridas na malha do projeto de Le Corbusier. Cada uma das versões da casa continha outras internamente, em menor escala, de modo que, assim como as bonecas russas, uma casa estava dentro de outra. A primeira era semelhante a uma maquete, a segunda seria do tamanho original e a terceira, que comportava as outras duas poderia ser portar como um museu das anteriores.

A Casa 11a foi um projeto realizado a pedido de Kurt Foster que no momento lecionava na Stanford University no momento que soube do projeto de Cannaregio. Ele fez o pedido a Eisenman na qual, quando ele estivesse dentro, se sentisse olhando para fora e, quando ele estivesse de fora, ele deveria se sentir como se estivesse dentro da casa. 


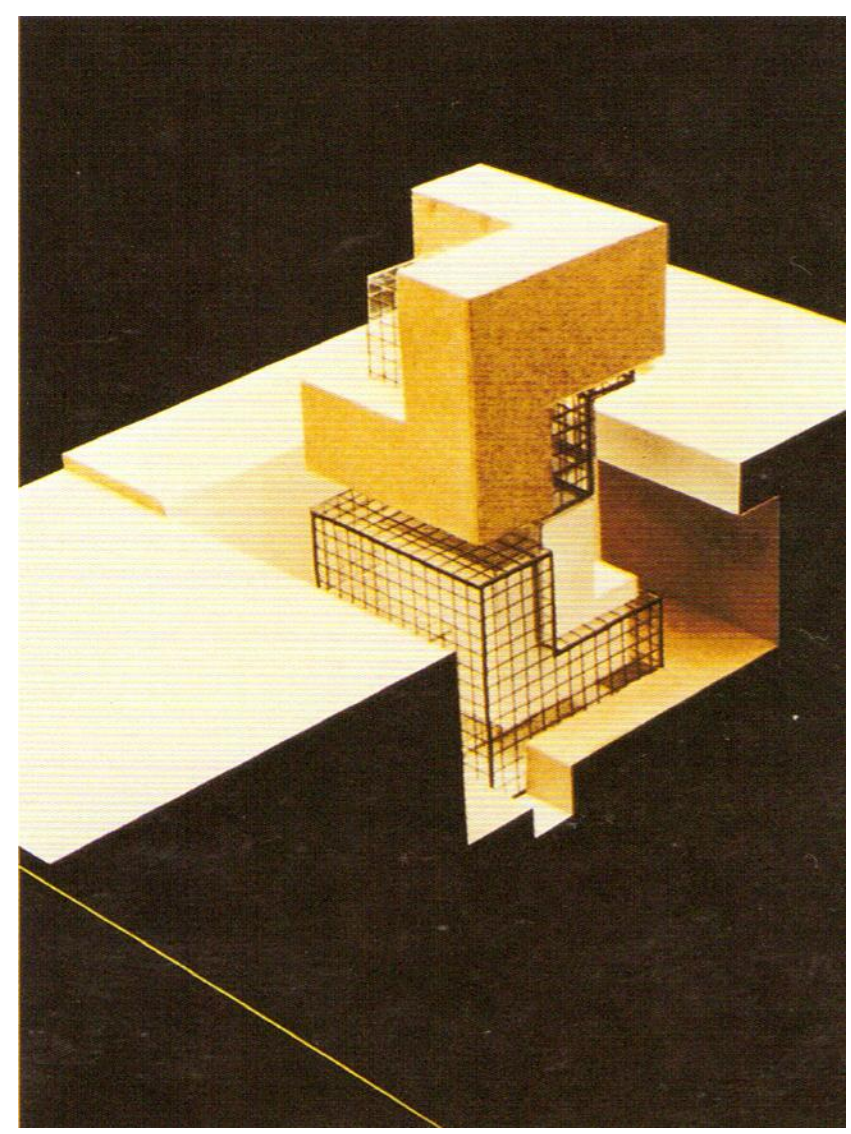

Figura 4.9 Casa 11a

A solução para este programa foi a criação de um vazio no espaço interno da casa de modo que ele nunca pudesse ser acessado. De acordo com Eisenman, uma vez dentro da casa observando este vazio inacessível, teria a impressão de ser algo externo porque não poderia ser acessado, mas ao mesmo tempo esta área "externa" seria o centro da casa, a parte mais interna. O usuário poderia caminhar por toda casa, subir e descer, mas nunca acessar este "vazio inacessível". Este tema interior/exterior acabou por sugerir a Eisenman uma imagem ${ }^{41}$ para o projeto, a fita de Möebius que possui uma superfície contínua sem definição do externo e interno.

"Diagramaticamente, a Casa 11a foi conceituada como uma fita de Möebius que poderia ser colocada metade subterrânea e metade acima do solo" ${ }^{42}$.

Eisenman menciona que no programa da casa, os andares inferiores correspondiam aos dormitórios enquanto nos superiores aparecia o vazio. Neste contexto, inferior e superior têm a mesma significação que dentro e fora do terreno, tema tal aproveitado no Cannaregio a fim de alimentar o conceito topológico do projeto.

\footnotetext{
${ }^{41}$ Eisenman a nomeou como diagrama.

42 "Diagrammatically, House 11 a was conceptualized as a Möebius strip that would be placed half underground and half above ground". EISENMAN, 1999, p. 176.
} 
Do mesmo modo que Eisenman utilizou a malha do hospital de Le Corbusier no projeto de Cannaregio, acontece semelhante no projeto "Berlin IBA Housing", com a superposição (diferente de sobreposição) de malhas urbanas históricas, uma malha moderna e a projeção de Mercartor (cartografia criada com o intuito de representar o globo terrestre). Neste projeto acontece a impressão destas malhas nos edifícios do programa, e do mesmo modo é feita com a altura do muro de Berlin, três metros de altura que foram marcadas na base do edifício sugerindo que haveria um novo terreno na cidade e este começaria aos três metros de altura. Eisenman afirma que este projeto foi o primeiro a tratar do tema de "escavação artificial" por criar este solo elevado, um novo plano de relações que aconteceria aos três metros de altura, ou seja, era a invenção de um terreno diagramaticamente ${ }^{43}$.

Eisenman ainda esclarece que apesar destes três projetos - Cannaregio, IBA tal como Wexner Center - trabalharem com diagramas exteriores e o conceito de escavação artificial, eles utilizavam diagramas bi-dimensionais e (ainda que permitissem serem extrudados) 'textos' que eram imanentes ao terreno/arquitetura construída. Os outros projetos que seguiram estavam mais próximos da crítica antes mencionada sobre a interioridade e sem a utilização de diagramas externos imanentes, mas transcendentes ${ }^{44}$ ao projeto, a possibilidade de desfocar a relação entre forma e função seria mais fácil.

Essa transcendência é criada na tentativa de retirar dos textos, dos diagramas usados, qualidades, características que possam relacioná-los à arquitetura e dificultar o desfoque da relação arquitetônica entre forma e função ${ }^{45}$. Neste sentido, malhas e eixos, por exemplo, não poderiam ser usados. Outro elemento asignificante deveria suprir o projeto

Neste momento seria apropriado diferenciar dois conceitos, o de traço e o de superposição.

\footnotetext{
${ }^{43}$ EISENMAN, 1999, p. 179.

${ }^{44} \mathrm{~A}$ independência de consciência. Um objeto que transcende $\mathrm{O}$ ato cognitivo contrapõe-se a ele como algo independente, não como algo só posto pelo ato.

${ }^{45}$ Não deve ser entendido como a dicotomia modernista, mas como a interpretação que Eisenman dá no início de suas casas - a de retirar significado da função da arquitetura como, por exemplo, uma coluna a-significante.
} 
"O diagrama arquitetônico, como o Bloco Mágico ${ }^{46}$, pode ser concebido como uma série de superfícies e ao mesmo tempo capaz de reter múltiplas séries de registros". ${ }^{47}$

Originalmente, em Freud, o bloco mágico ou Wunderblock, em alemão, é uma metáfora que tenta exemplificar as propriedades da memória, de como o tecido nervoso se altera por efeito de um fato.

"'mas, se olharmos mais de perto, descobriremos na sua construção [do bloco] uma notável analogia com o que supus ser a estrutura do nosso aparelho de percepção'. [....'Uma superfície de recepção sempre disponível e marcas duradouras das inscrições recebidas'"

Atualmente reconhecemos este bloco mágico como um brinquedo infantil que possui um conjunto de duas camadas. A primeira camada é uma superfície plástica (anteriormente era um folha de celulóide transparente) que fica repousada sobre uma camada de cera que é a segunda camada. Quando a superfície do plástico é riscada com algum lápis ou qualquer outro objeto pontiagudo, é possível elaborar desenhos ou escrever no bloco porque os sulcos do objeto pontiagudo, no contato da cera com o plástico, formam linhas escuras. Caso queira limpar o que foi escrito, apagar os desenhos, simplesmente levantamos a camada plástica e os desenhos registrados desaparecem. Ao repousar novamente a superfície plástica sobre a cera, o bloco está pronto para receber outro desenho.

\footnotetext{
"Desprezando as 'pequenas imperfeições' do dispositivo, interessando-se apenas pela analogia, Freud insiste no caráter essencialmente protetor da folha de celulóide. Sem ela, o papel de cera fina seria riscado ou rasgado. (...) 'A folha de celulóide é, portanto um véu protetor para o papel de cera'. Mantém-no ao abrigo das 'influências ameaçadoras provenientes do exterior'. (...) Se retirarmos da tabuinha toda a folha de cobertura - celulóide e papel de cera - o escrito apaga-se e, como fiz notar, não mais se reconstitui em seguida. A superfície do bloco mágico está virgem e de novo receptora. Mas é fácil constatar que o traço duradouro do escrito se mantém na tabuinha de cera e permanece legível com uma iluminação adequada". ${ }^{48}$
}

O diagrama, como um bloco mágico, contém a simultaneidade de aparência em sua superfície, que seria semelhante às linhas pretas na camada superior do bloco, assim como as marcações na cera abaixo. Deste raciocínio Eisenman defende a não linearidade do diagrama uma vez que, como o bloco mágico, ele imprime dados, mas não em uma ordem cronológica. Os dados que são aparentes

\footnotetext{
${ }^{46}$ Mystic Writing Pad, em inglês.

${ }^{47}$ Ibid.. p. 33.

${ }^{48}$ DERRIDA, 2005. p. 216-218.
} 
são os mesmos que as impressões profundas na cera (percebidas ao inclinar a tábua com a cera e olhando-a próxima à luz).

Deste conceito de sobrepor uma camada sobre a outra, sendo uma um filtro e a outra um registro, chegamos ao conceito chave para entender os diagramas recentes de Eisenman.

“'De um diagrama ao próximo, novos mapas são desenhados; então não existe diagrama que, apesar disso, não inclua também os pontos, que conectam (ou seja, para além de sua componente estrutural) pontos relativamente livres ou pontos desconectados, pontos de criatividade, mudança e resistência ao edifício existente ${ }^{, 49}$. Neste sentido, diagramas são aquelas forças que aparecem em toda relação de um ponto a outro, como mapas superpostos". 50

Eisenman segue explicando a diferença do conceito de superposição do de Deleuze e de seu conceito de sobreposição. Para Eisenman, Superposição refere-se a uma estratificação, diferenciando figura e fundo. Já o seu termo de sobreposição é vinculado a um modo de relacionamento entre os estratos de modo horizontal, coextensivo não existe fundo estável ou percebido, uma origem. Figura e fundo flutuam na mesma camada e entre si. ${ }^{51}$

Este conceito de traços e superposição é o fundamento sobre o qual apóia a arquitetura e o processo de Eisenman exposto. Iniciado no projeto de Cannaregio, ele é desenvolvido como superposição de textos externos a partir do projeto do Biocentro de Frankfut em 1986-87 apesar de o autor mencionar que foi no projeto Moving Arrows, Eros, and Other Erros (Romeo + Juliet Castles) para a Terceira Bienal Internacional de Arquitetura de 1985.

\footnotetext{
49 Podemos encontrar em DELEUZE, 2006. p. 53: "De um diagrama a outro novos mapas são traçados. Por isso não existe diagrama que comporte, ao lado dos pontos que conecta, pontos relativamente livres ou desligados, pontos de criatividade, de mutação, de resistência; e é deles, talvez, que será preciso partir para se compreender o conjunto".

${ }^{50}$ EISENMAN, 1999. p. 29.

${ }^{51}$ Ibid.. p. 29.
} 


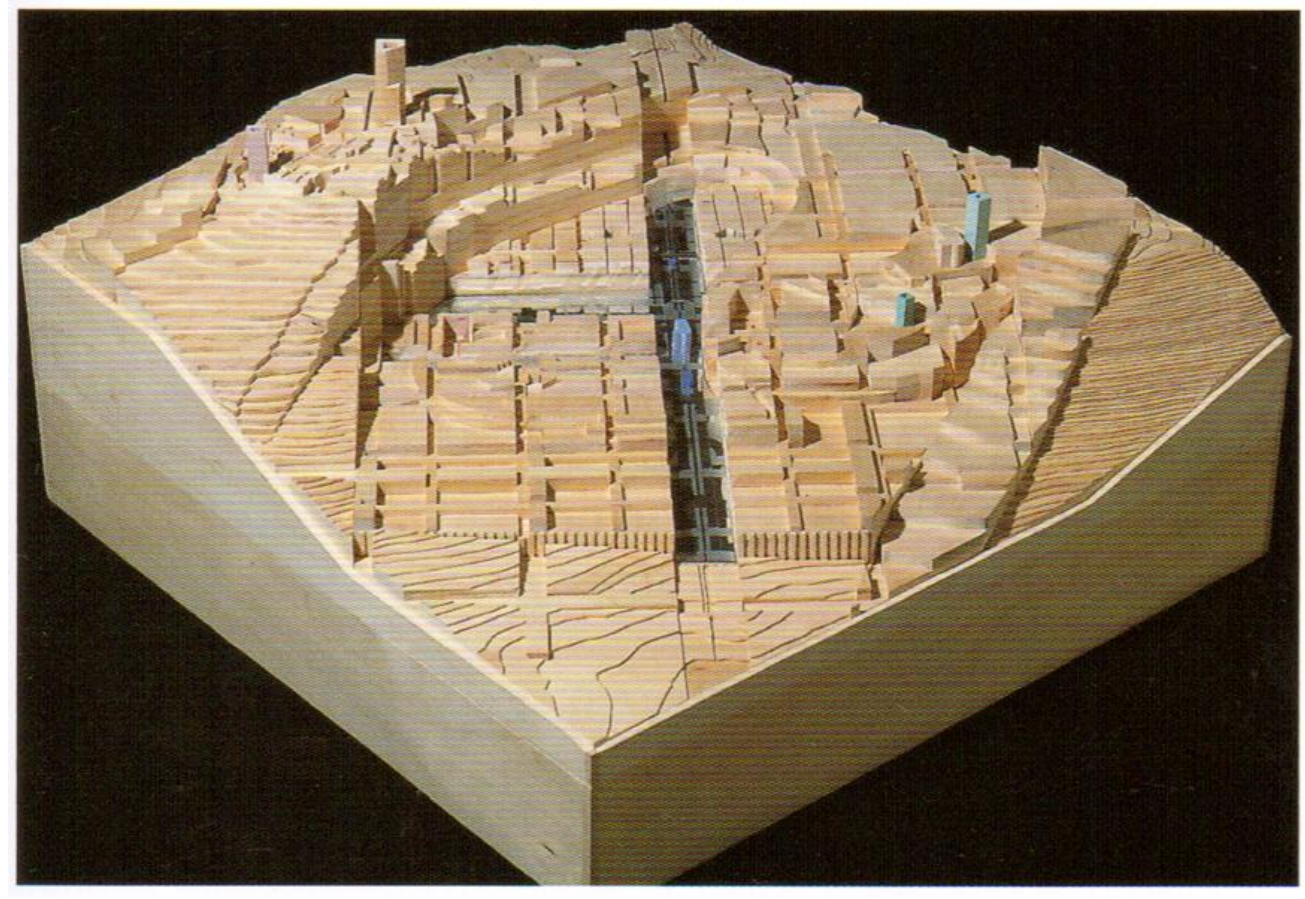

Figura 4.10 Romeo + Juliete
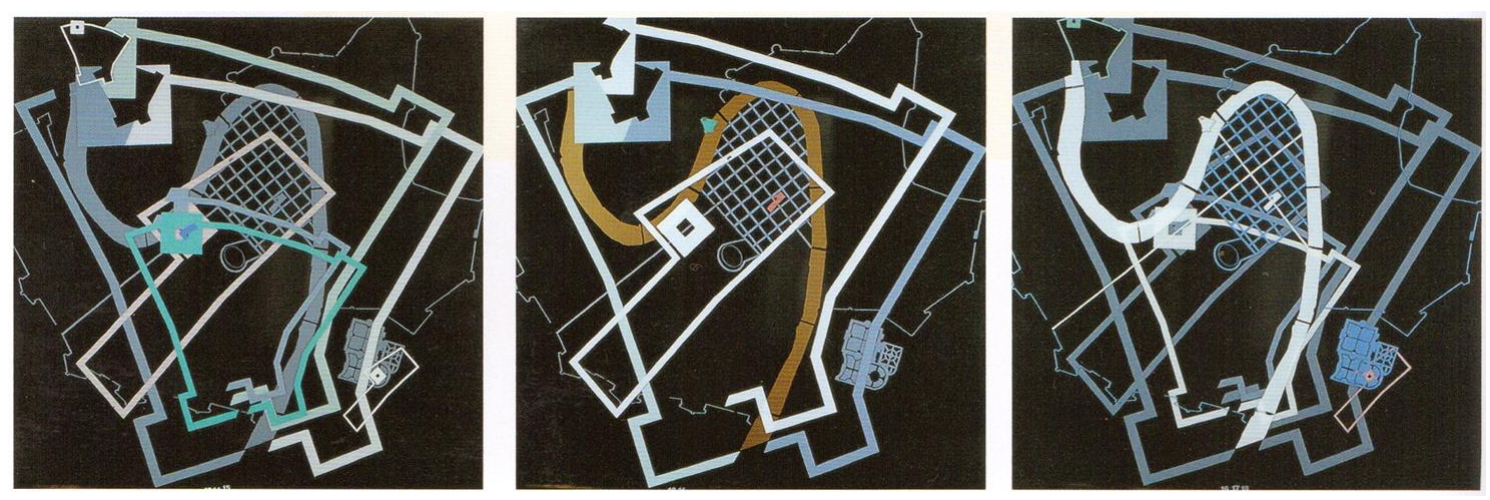

Figura 4.11 Sobreposição de plantas. Castelos de Romeo e Juliete

Este projeto foi composto por duas sobreposições: a casa de Julieta sobreposta ao seu castelo assim como a casa e o castelo de Romeo. Mas como o autor mencionou que os diagramas tentavam transcender o tema arquitetônico, consideramos que o projeto seguinte, do Biocentro de Frankfurt é que instaura esta passagem de um estágio de diagramas imanentes a diagramas transcendentes. 


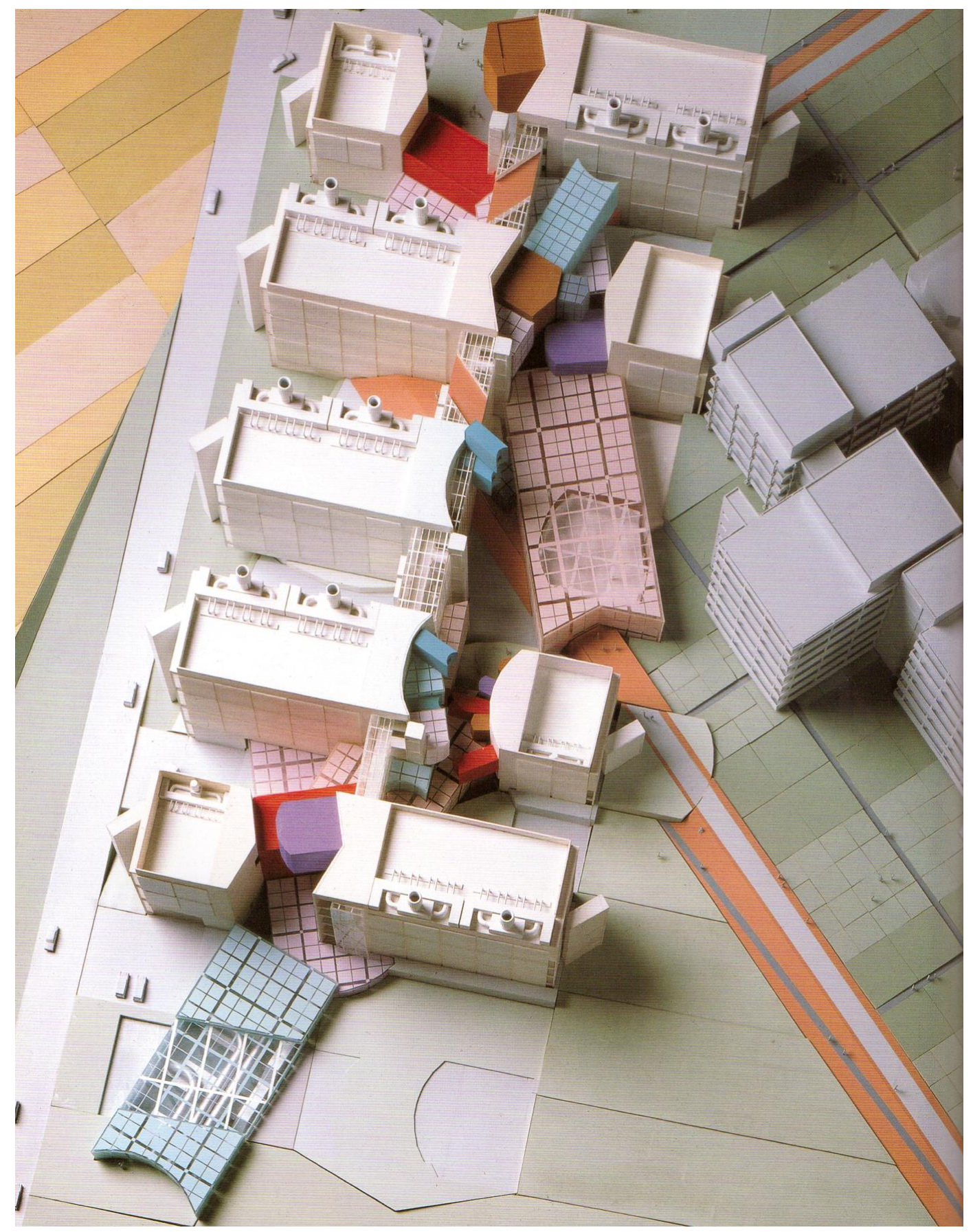

Figura 4.12 Biocentro

Neste projeto Eisenman utiliza da imagem da molécula de DNA correspondente à proteína "colágeno" que produz a estrutura tênsil necessária para ossos e músculos. Cada processo biológico foi representado neste projeto e utilizado como ferramenta metodológica: replicação, transcrição e tradução com as formas que, a princípio, como na cadeia de DNA, se combinam em pares. 
Apesar de caracterizarmos este projeto do Biocentro como detentor de um diagrama totalmente externo, Eisenman afirma que não, uma vez que a imagem da molécula de DNA está implícita na função para a qual o edifício é destinado.

Assim podemos citar outro projeto que utiliza diagramas menos imanentes possíveis, que é o projeto para o Parque La Villette de 1987. Aqui Eisenman traz o projeto antes elaborado, o Cannaregio e o imprime sobre o terreno de La Villette. Eisenman justifica sua escolha por ambos os projetos dizendo que os terrenos tiveram grandes açougues em sua história. $O$ processo de impressão e uma posterior retirada da imagem de Cannaregio fez com que registros deste processo ficassem presentes no terreno do La Villette ${ }^{52}$.

Mas até agora o que Eisenman tem visto como diagrama ainda percorre o tema da sobreposição que é uma variação do tema de figura-fundo. Esta sobreposição ainda mantém a percepção de uma relação direta entre os mapas utilizados. Como no IBA ainda podemos destacar, mesmo que sobrepostos, os diagramas históricos do moderno e a presença do muro de Berlin. Mas no ano de 1990 Eisenman traz outra metodologia derivada desta sobreposição que é o tema da dobra

Não verificamos a princípio alguma relação do tema dobra de Eisenman com o de Deleuze e Guattari tal como percebemos com Derrida. Tal processo, afirma Eisenman, permite uma interação mais intensa entre os diagramas no momento que uma distorção é feita na estrutura de tais mapas criando outros mapas. Tal processo foi chamado de morphing e foi utilizado nos seus projetos seguintes, tal como a Igreja do Ano 2000.

52 Sabemos que Jacques Derrida efetua parceria com Eisenman e Tschumi neste projeto. É perceptível uma interferência de Derrida em Eisenman neste momento. É clara, nas descrições de Eisenman sobre La Villette, a similaridade de raciocínio desta sobreposição/remoção do projeto de Cannaregio com a descrição do Bloco Mágico de Freud (usada por Derrida) feita nesta dissertação. 


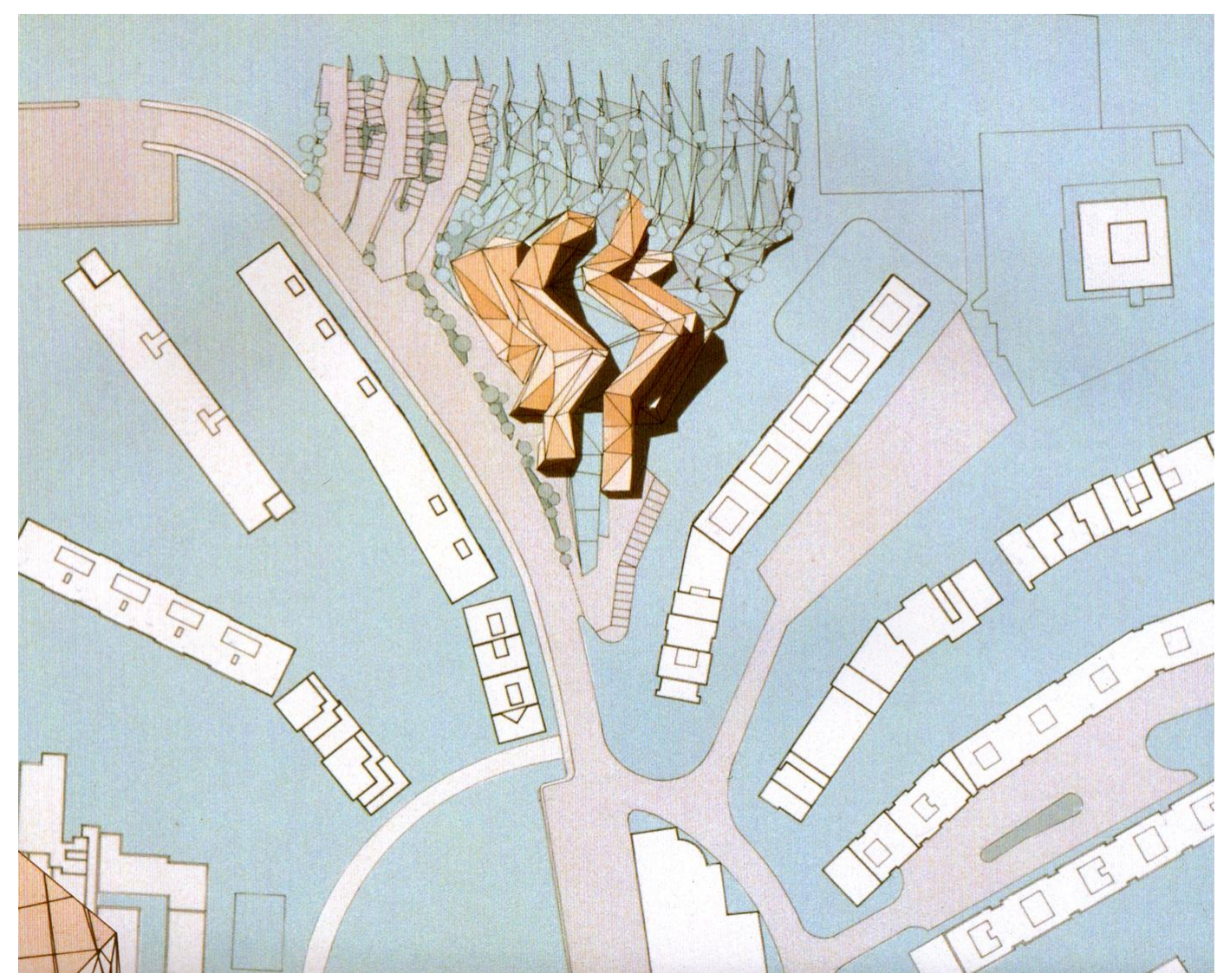

Figura 4.13 Implantação do projeto Igreja do ano 2000 - 1996

Neste projeto Eisenman utiliza de um diagrama externo, uma imagem das moléculas do cristal líquido, utilizando, neste processo, o comportamento das moléculas do cristal como padrão de transformação do diagrama molecular inicial. Quando um conjunto de moléculas de cristais está em estado sólido, elas são ordenadas paralelamente, ao passo que quando aquecidas em direção a um estado líquido elas alteram sua disposição de modo "desordenado". Esta lógica transformacional é utilizada em Eisenman no intuito desse diagrama do cristal alterar também o terreno onde é projetado o edifício. Neste processo são identificadas as possibilidades volumétricas que deram forma ao edifício. 


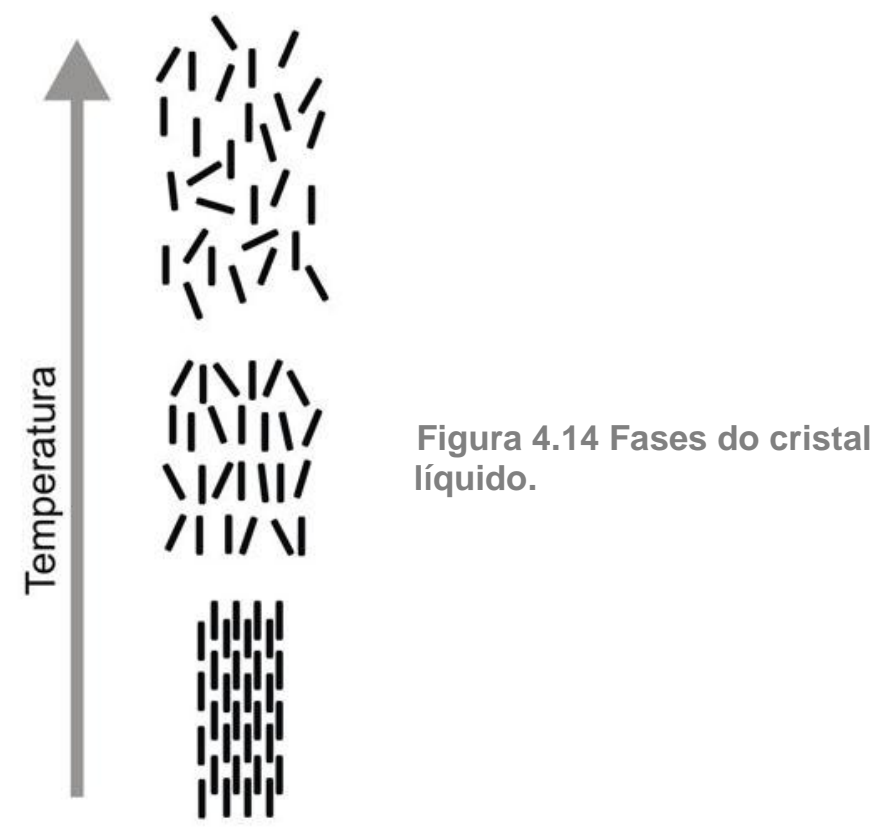

Mas existe uma questão que vem à tona em todos estes procedimentos de sobreposição que é como acontece a passagem do diagrama, do amálgama instável a consolidação do projeto?

Eisenman, na sua entrevista com Zaera-Polo na revista El Croquis ${ }^{53}$ lança o tema do arbitrário e intencionalidade em suas arquiteturas. Questionado sobre a existência de uma intencionalidade necessária em toda obra, Eisenman menciona que até o momento suas obras não têm uma intencionalidade a priori porque isso direcionaria o projeto no caminho inverso de sua pesquisa que é de romper paradigmas significantes tradicionais na arquitetura. Assim, existe uma arbitrariedade tal como ocorre em um processo científico, ou seja, em seu primeiro movimento em direção a uma descoberta, existe uma decisão arbitrária, um "ato de fé", mas que nos momentos seguintes sempre haverá uma intencionalidade. ${ }^{54}$

Sobre sua interpretação do programa do edifício no processo, já demonstramos que não é o ponto focal, ele deve ser omitido como premissa e às vezes questionado, mas ele traz uma nova informação. Em sua entrevista, afirma que o programa é deixado em suspensão, entre o mecanismo de projeto e as próprias respostas subjetivas que 0 arquiteto desenvolve. ${ }^{55} \mathrm{O}$ controle de suas

\footnotetext{
${ }^{53}$ El Croquis, número 83 ano 1997, p, 6-20.

${ }^{54}$ Ibid., p. 10.

${ }^{55}$ Ibid., p. 13.
} 
ações sobre um projeto, estabelecendo uma crítica constante é carregado de uma intencionalidade, uma vez que "não se pode ter controle sem intencionalidade. Precisa haver uma meta-intencionalidade". ${ }^{56}$

Se nos direcionarmos para o estudo do processo de projeto de Eisenman como um deus ex machina, imaginando que não existe uma intencionalidade ou que os projetos são desenvolvidos de maneira aleatória e que o diagrama se instaura pela orientação de Eisenman como um mecanismo praticamente autônomo, iremos ter uma leitura errônea e perigosa do arquiteto, de suas teorias, das obras, assim como do processo. O que ele afirma claramente é:

"não interessa o meta-processo, e sim a possibilidade de uma metaescritura que surja do processo. (...) Estou interessado na noção de poder criar a partir de vazios iniciais, ao invés de partir de sólidos(...). Nenhum de meus trabalhos nascem da metodologia ou da teoria, mas da evolução de meu trabalho tal e como tenho experimentado". ${ }^{57}$

E ainda:

"[meu trabalho] não representa um progresso, mas o perambular de uma mente inquieta. Não acredito na idéia de um progresso mais do que acredito nos outros ismos do passado. O 'Zeitgeist' é pra mim uma atitude moral de estar no presente...Talvez isto venha de uma atitude judia. Os judeus crêem que não existe um estado futuro, só existe o presente..." ${ }^{58}$

Já que a arquitetura de Eisenman é uma arquitetura crítica, um meio pelo qual ele explora os tropos da arquitetura $^{59}$ e desvincula o sujeito de um ambiente já significante (tal como retirar um quadro do museu e apresentá-lo em outra ocasião), podemos ver que o processo a ser estudado se dá no momento inicial de seus projetos. O que acontece nos momentos seguintes, se satisfeito pela produção crítica inicial, tem uma importância secundária nesta crítica. Tal como mencionou, sua preocupação não se dá pelo processo, mas pelo que ele cria através de sua meta-escritura.

Uma imagem retirada do livro Tracing Eisenman nos traz novos questionamentos.

\footnotetext{
${ }^{56}$ EISENMAN, in El Croquis, 1997, p. 17.

57 lbid., p. 20.

58 lbid., p. 13.

59 lbid., p. 20.
} 

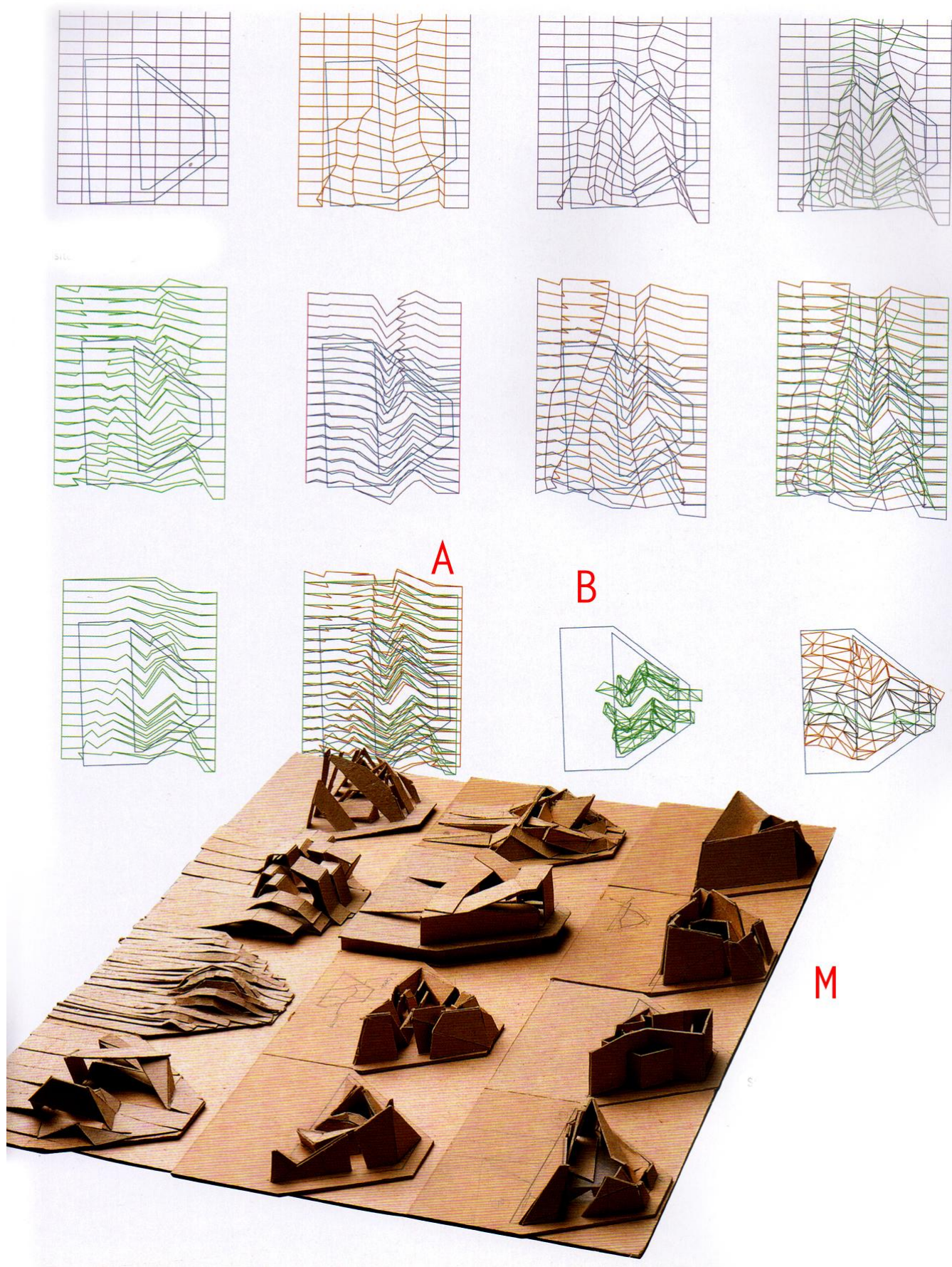

Figura 4.15 Igreja do ano 2000 - 1996 


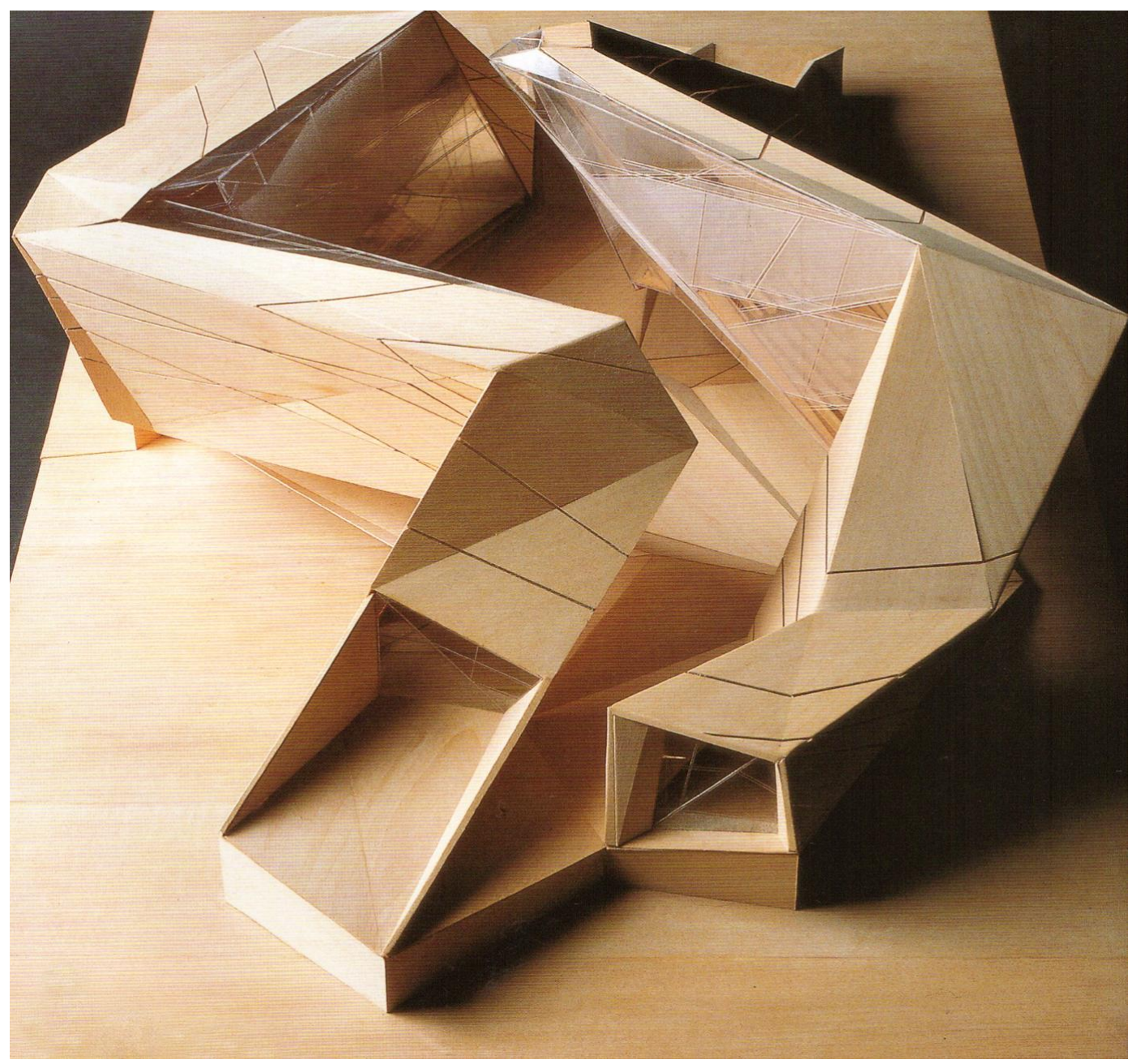

Figura 4.16 Modelo final

O modelo que aparece na imagem 4.15 entra em um momento onde 0 diagrama já ativou uma série de relações que foram percebidas e coordenadas (momento A). A partir da informação gerada pelos diagramas sobrepostos e fundidos, Eisenman parte ao uso de maquetes (M) para definição de outra problemática- seja programa, adaptação a uma espacialização sugerida pelo diagrama ou qualquer outra que esteja no escopo do trabalho. A partir desta pesquisa no modelo físico, neste projeto, ele parece retomar (momento B) ao diagrama para conformar o projeto a outra geometria que esteja relacionada tanto com os diagramas anteriores como àquelas decisões tomadas no modelo.

Para Eisenman os diagramas não podem ter uma dimensão estruturada, nem informal. Eles têm um funcionamento abstraído de qualquer uso específico. O diagrama não é mais, como anteriormente usado em arquitetura, um arquivo visual, mas um mapa, uma cartografia ou uma escrita que é uma máquina abstrata cujo 
funcionamento é através da operação de séries de processos que alargam a forma e a matéria, (abstratamente) de modo a abrir as lacunas existentes para outras funções e outras questões a serem formadas ${ }^{60}$.

"[uma nova geração de arquitetos] está propondo uma nova teoria do diagrama baseada parcialmente na interpretação de Gilles Deleuze da reformulação de Foucault sobre diagrama como 'uma série de forças maquínicas', e parcialmente em suas próprias alucinações cibernéticas. Em suas polêmicas o diagrama tornou-se uma palavra-chave na interpretação do novo. Esta questão desafia tanto as bases geométricas tradicionais do diagrama e da história sedimentada da arquitetura, e, ao fazê-lo, elas questionam qualquer relação do diagrama com a anterioridade ou interioridade da arquitetura". ${ }^{61}$

Neste sentido ele aponta Greg Lynn ${ }^{62}$ e faz referência às arquiteturas paramétricas e algorítmicas desenvolvidas recentemente de onde trazemos 0 escritório holandês UN Studio, de Ben van Berkel e Caroline Bos, como meio de nos informar de outra visão diagramática da arquitetura.

\footnotetext{
${ }^{60}$ Diagramas, então, formam questões visíveis e formalizam funções articuláveis" . EISENMAN, 1999, p. 30.

61 EISENMAN, 1999, p. 29.

62 Também pode ser considerado representante do método diagramático de projeto, como apontou SPERLING, 2003.
} 
[Análise do conceito de diagrama em UNStudio] 


\title{
CAPÍTULO 5 - UNStudio e a potência diagramática
}

Durante a década de 90 acontece uma radical transformação tanto no âmbito físico como espacial na Holanda, promovida por meio de uma democracia baseada em sistemas experimentais e expansão do envolvimento dos cidadãos que acabou por criar uma nova reorientação política, econômica, social e ideológica em um novo tipo de relação com o ambiente construído através de novas formas de redes de comunicação.

Constanzo ${ }^{1}$ nos descreve que a Holanda passava por uma condição "inicial de modernidade" baseada na idéia de nação-estado, de uma sociedade voltada para relações interpessoais, redes de comunicação, progresso, uma alta taxa de empregabilidade e, sobretudo, baseada em modelos de vida coletivos dentro de uma "segunda modernidade" que levou à uma profunda reformulação de conceitos em arquitetura, planejamento urbano e paisagem.

\begin{abstract}
"Enquanto esta nova visão teoricamente trouxe com ela a necessidade de redefinir noções como espaço, distância, lugar e ambiente habitável, em termos concretos isto causou mudanças notáveis na cidade e na imagem da paisagem urbana". ${ }^{2}$
\end{abstract}

Neste momento, através do simpósio "Quão moderna é a arquitetura Holandesa" ${ }^{3}$ organizado por Rem Koolhaas em 1990 e da Bienal de Veneza em 1991, é explicitado um grupo de arquitetos holandeses ${ }^{4}$ que, de acordo com Constanzo, traziam uma liberdade projetiva baseando-se desde Jan Duiker(18901935) a Álvaro Siza (1933) como suas fontes de inspiração.

No ano de 1999 Ben van Berkel e Caroline Bos fundam o escritório UNStudio com a idéia de formação de um ambiente colaborativo (daí vem o nome UN - United Network). Talvez movidos por seus laços acadêmicos, os fundadores formaram um

\footnotetext{
${ }^{1}$ CONSTANZO, 2006.

2 "While this new vision theoretically brought with it the need to redefine such notions as space, distance, place, and habitable environment, in concrete terms it caused noticeable changes in the city and in the image of the urban landscape". Ibid., p. 9.

3 "Hoe modern is de Nederlandse architectuur?"

${ }^{4}$ Incluídos neste grupo ainda estão o escritório MVRDV, NOX, Kas Oosterhuis, Wiel Arets, Erick van Egeraat, Mecanoo, Willen Jan Neutelings, Claus en Kaan, Koen van Velsen e West 8.
} 
escritório que trabalha com projetos em uma ação dinâmica e inclusiva que se concluía em contribuições práticas e teóricas na crítica da arquitetura.

"Com nosso livro Mobile Forces(1995), nós tomamos a iniciativa de articular arquitetura como uma prática material após o campo, durante décadas, ter sido dominado por uma aproximação lingüística, conceitual." 5

Os arquitetos defendem a idéia de abolição de modelos como método de ensino de arquitetura. Eles apresentam-se favoráveis a um novo paradigma de ensino em arquitetura que, se antes eram baseado em modelos de ensino, hoje deve ser focada em questões reais e atuais, vistas e pensadas através de pesquisas e experimentações.

Percebe-se que não se trata de mudar a tecnologia ou a sociedade, a alteração não está no ferramental nem nas condições em que ela realiza, mas em quem as realiza. Trata-se, enfim, de mudar o arquiteto e, para isso, deve mudar o quê ele apreende e como ele aprende, ou seja, seu ensino.

"Move introduz inclusividade na abordagem do projeto; (...) Inclusividade permite fragmentação e diferença a serem absorvidos em uma aproximação contínua e coerente, abandonando as estratégias de fragmentação e colagem".

O livro "Move" analisa como os arquitetos estão se comportando com a constante mudança de padrões e como suas imaginações, suas criatividades respondem a estas mudanças. Os autores afirmam que processos difusos e fluidos possuem uma dimensão política que deve ser assimilada pelos arquitetos a fim de trabalharem com os grandes projetos dessa época que pede por processos fluidos, dinâmicos e interativos. A mudança do arquiteto anterior para o atual deve levar em conta a compreensão e entendimento da reunião entre construção, programa e circulação.

Assim, o quadro em que a arquitetura se encontra é esse:

"Hoje, a imaginação arquitetônica é influenciada pelas dinâmicas da sociedade, a simultaneidade da diferença local e homogeneidade global que têm alterado profundamente nosso pensamento sobre estruturas. Os caminhos nos quais o mundo está organizado têm se liquefeito em diversos

\footnotetext{
5 "With our book Mobile Forces (1995), we took the initiative to articulate architecture as a material practice, after the field had for some decades been dominated by a conceptual, linguistic approach" BERKEL; BOS, 2006, p. 11.

6 "Move introduces inclusiveness in the design approach; (...) Inclusiveness allows fragmentation and difference to be absorbed into a coherent, continuous approach, abandoning the strategies of fragmentation and collage". Ibid., 1999, v. 1, p. 15.
} 
níveis. [...] Como diferentes sistemas de pensamento infiltram um ao outro, ordens presumidas e estratificadas desapareceram em vários níveis. Forças energéticas inerentes moldam todas as estruturas organizacionais. Estruturas não mais representam sistemas homogêneos, lineares, mas campos em processo de materialização. Estes estão baseados em mecanismos espaciais e materiais e suas naturezas dissipativas fornecem energias incorporando genética, química, economia, cultura e informação política dentro e fora do fluxo". ${ }^{7}$

Ben van Berkel e Caroline Bos ressaltam que apenas a arquitetura e o urbanismo estariam atrasados ao incorporar novas mídias. De acordo com os arquitetos, a disciplina possui uma dificuldade imediatamente percebida ao apropriar-se de novas mídias porque é um produto real, físico, um espaço a ser vivenciado. Mas de outro modo também é instável porque recebe o suporte de novas tecnologias construtivas continuamente e como dever, os arquitetos têm que procurar relevância nas novas práticas, eventos e tecnologias.

Van Berkel afirma que não acredita em um modelo tradicional formado por um arquiteto que comanda uma equipe subordinada a ele ${ }^{8}$. O trabalho deve ser homogêneo e as novas práticas e tecnologias ajudam este relacionamento.

A expressão usada "toda tecnologia é social antes de se tornar técnica" traz consigo o sentido de que as tecnologias devem ser incorporadas na prática de arquitetura e serem mais bem compreendidas e suportadas antes de serem completamente exploradas como ferramenta, assim, para van Berkel e Bos, existem três potenciais arquitetônicos trazidos através de mediação tecnológica: o potencial de expansão da imaginação espacial, o de um rompimento radical na hierarquia do projeto e o potencial de introdução de novas disciplinas no processo de projeto, que remete a interpretação de uma disciplina não mais autônoma, mas multidisciplinar.

O primeiro potencial evocado refere-se à possibilidade de explorar condições espaciais, uma possibilidade de experimentação multidimensional e de novas conceituações espaciais. Já o segundo, trás um novo entendimento de projeto onde a condição da existência de uma planta térrea não é mais necessária para o

\footnotetext{
7 "Today, the architectural imagination is influenced by the dynamics of society and the simultaneity of local difference and global homogeneity, which have profoundly changed our thinking about structures. The ways in which the world is organized have liquefied on many levels. [...] As different thought systems infiltrate each other, presumed stratified orders disappear on many levels. Inherent energetic forces shape all organizational structures. Structures no longer represent homogeneous, linear systems, but process fields of materialization. These are based on spatial and material devices and their dissipative nature allows energies incorporating genetic, chemical, economic, cultural and political information to flow in and out'. VAN BERKEL; BOS, 1999, v. 1, p. 21-23.

${ }^{8}$ VAN BERKEL, BOS, 2009.
} 
desenvolvimento de um projeto. Este processo não é mais dependente de uma hierarquia desenvolvida a partir da planta térrea de onde se desenvolvem os outros andares. Além desta, outra quebra acontece quando as relações entre as partes do objeto também podem ser pensadas e planejadas (as relações entre as partes podem ser estudadas e definidas). Por sua vez, o terceiro potencial é o corrente em arquitetura, e se fizermos um estudo histórico iremos perceber que, desde a ldade Média, outras disciplinas são incorporadas à arquitetura. ${ }^{9} \mathrm{~A}$ arquitetura se abre a intervenção e suporte de outras disciplinas no processo de projeto.

Por meio destes potenciais retratados, van Berkel e Bos apontam quatro aproximações tecnológicas através das quais as tecnologias digitais podem ser generalizadas como virtualização e interação. A primeira dentre as quatro aproximações é a realidade virtual. A criação de um espaço (cyberespaço) virtual ${ }^{10}$ onde a materialidade do objeto real (e do espaço) é apenas representada, mas permite intervenções conceituais, fantásticas, econômicas e sociais. Deste modo explora-se o inventivo e utópico potencial das novas mídias expandindo fronteiras. ${ }^{11}$

Na virtualização de um objeto implica-se virtualização das relações, que é a segunda aproximação tecnológica.

Tradicionalmente os arquitetos e outros participantes do projeto e construção do edifício estavam em relativo isolamento, mas com as tecnologias em projeto, eles podem participar ativamente de um ambiente conjunto com outros membros em processos colaborativos e efetuar cálculos complexos através de simulações matemáticas em softwares. Detalhes podem ser pensados e, através de cortes em máquinas a laser, as peças podem ser produzidas rompendo com uma possibilidade única de geometria.

Outro ponto levantado remete à crítica do Modernismo como uma lógica de linguagem padronizada que perdeu seu imperativo. ${ }^{12}$ Esta terceira aproximação se mescla à quarta e traz à tona o conceito de parametrização em arquitetura. Como discutem os autores:

\footnotetext{
${ }^{9}$ Podemos interpretar que nas catedrais góticas havia uma realização tanto arquitetônico-estrutural como escolástica.

${ }^{10}$ Diferente do conceito de virtual de Deleuze e Guattari mostrado no capítulo três, este virtual remete à digitalização das relações, à imaterialidade.

11 BERKEL; BOS, 1999, v. 2, p. 162.

${ }^{12}$ Op. cit., p. 164.
} 
"Se qualquer forma é possível e são igualmente funcionais em termos econômicos (...) um simples, auto-evidente pensamento não mais justifica uma forma específica". ${ }^{13}$

Este raciocínio expõe um processo de projeto que possui a tentativa de reduzir a dependência da personalidade do arquiteto ou convenções estéticas ${ }^{14}$. Van Berkel e Bos atentam para a animação como um passo adiante que envolve uma modelagem e pensamento de um percurso onde o processo se gera. $O$ projeto é o resultado do processo, solidificação de energias que atuam umas sobre (e nas) outras. A animação abandona toda rede de pontos que geram um objeto e trabalha com inter-relações de parâmetros e forças ${ }^{15}$ e esta técnica, a animação, é um processo que não poderia ser desenvolvido sem a virtualização da arquitetura.

\begin{abstract}
"Do ponto de vista prático, o avanço de novas técnicas é uma parte essencial de conceituação, mais do que responder a mudança; os efeitos concretos e visuais gerados pelo desenvolvimento de novas técnicas que, por si só, são instrumentais em formar o conceito. Você pode já ter visto novos efeitos e novos modos de organização em uma tecnologia recente". ${ }^{16}$
\end{abstract}

Van Berkel e Bos esclarecem sua preferência e uso dos computadores no projeto afirmando que, juntamente com técnicas de mediação, o computador representa um invento extremamente importante no século $X X$ devido à sua capacidade de armazenamento, combinação e manipulação de informação além de fazer com que o tempo seja visível e calculável. ${ }^{17}$ Esta ferramenta revela e trabalha em âmbitos múltiplos, em um mundo de comunicações multiplicadas no qual tudo e todos estão conectados através de tecnologias que são baseadas em flexibilidade, mobilidade e sistemas operacionais dentro de uma rede invisível. ${ }^{18}$

Tais tecnologias nos fornecem a informação que recebemos e enviamos, fornecendo uma imagem e uma reorganização do mundo que conhece(re)mos.

Nesse sentido, cientes do potencial multiplicador e conectivo do computador e das técnicas de mediação, lançam a questão: Quais seriam as técnicas apropriadas

\footnotetext{
${ }^{13}$ BERKEL; BOS, 1999, v. 2, p. 164.

${ }^{14}$ Ibid., p. 165.

${ }^{15}$ Ibid., p. 166

16 "From the practitioner's viewpoint, the advancement of new techniques is an essential part of conceptualizing, rather than responding to change; the concret, visual effects generated by the development of new techniques themselves are instrumental in shaping the concept. You can already see new effects and new models of organization in a new technology". Ibid., p. 16

${ }^{17}$ lbid., loc. cit.

${ }^{18}$ Ibid., p. 17.
} 
para a arquitetura instrumentalizar esta nova cosmologia para seus próprios fins? Logo expõem a sugestão: diagramação, hibridação e mediação.

O uso de diagramação, de acordo com os autores, possibilita um ponto estável, dentro de um fluxo de informação da era midiática. Esse fluxo gera uma repetição constante de signos acabando por gerar um excesso de significação e, devida a esta sobrecarga, uma a-significância.

Assim, o diagrama se apresenta como um mecanismo instrumentalizador, organizador, que gera sentidos e conduz a arquitetura além de uma fixação tipológica.

\begin{abstract}
"De modo geral, diagramas são mais bem conhecidos e entendidos como ferramentas visuais usadas para compressão de informação. Um diagrama especialista, tal como um gráfico estatístico ou uma imagem esquemática, pode conter muito mais informação em poucas linhas tal como páginas cheias de textos". ${ }^{19}$
\end{abstract}

De um modo geral o diagrama pode ser entendido desta forma, como um mapa de relações entre objetos, tal como desenvolvido por Peirce. Mas em arquitetura, de acordo com van Berkel e Bos, diagramas têm sido introduzidos nos últimos anos como parte de uma técnica que promove uma proliferante, geradora e instrumentalizadora aproximação ao projeto.

\begin{abstract}
"A essência da técnica diagramática é que ela introduz no trabalho qualidades que não são faladas, desconectadas de um ideal ou uma ideologia, aleatória, intuitiva, subjetiva, desvinculada da lógica linear qualidades que podem ser físicas, estruturais, espaciais ou técnicas" ${ }^{20}$
\end{abstract}

Van Berkel e Bos remetem ao exemplo do panóptico para uma interpretação do conceito de diagrama. Para eles, a disposição da planta do Panóptico, do século XVIII "incorpora inúmeros níveis de significância e não pode ser reduzido a uma leitura singular; como todos os diagramas, o Panóptico é uma diversidade" ${ }^{21}$. Ele é a expressão de situações culturais e políticas em uma manifestação de vigilância.

Este é um ponto chave na conceituação do escritório sobre o tema de diagrama.

\footnotetext{
${ }^{19}$ VAN BERKEL; BOS, 1999, v. 2, p 19.

${ }^{20}$ Ibid., loc. cit.

${ }^{21}$ Ibid., p. 20.
} 
"Leituras críticas de interpretações prévias não são diagramáticas. Colocando nos termos mais simples possíveis, uma imagem é um diagrama quando ela é mais forte que suas interpretações". ${ }^{22}$

O diagrama, tal como um conceito, possui uma força geradora, possui uma síntese relacional de imagens, textos e linhas; ele é rico em significado.

Talvez possamos compará-lo, neste momento, à definição de monumento de Argan como um edifício que conserva seu valor e o transmite além de sua própria amplitude histórica ${ }^{23}$. Assim, o diagrama, inicialmente é entendido como uma forma significante, potencial.

No momento que um diagrama cria novos significados, ele relaciona novos entendimentos, mas van Berkel e Bos afirmam que estes significados ainda estão relacionados à sua substância, sua manifestação tangível. A assimilação de um conceito na arquitetura deve passar por uma mediação, ele não pode ser aplicado diretamente.

A correspondência entre uma situação e um produto gerado através dela deve ser permeada por um diagrama.

Um conceito observado não pode ser aplicado diretamente, deve haver um mediador que Van Berkel e Bos definem como papel do diagrama. Não uma planta ou um projeto executivo de algo; ele não é uma representação, e sim, uma geração.

A mediação gerada pelo diagrama em traduzir um conceito não deriva da forma que ele é criado, ou seja, pelas informações que são estabelecidas nele, mas de sua configuração, do modo que tais informações estão se relacionando.

Assim:

"o diagrama não é uma metáfora ou um paradigma, mas uma 'máquina abstrata' que é tanto conceito como expressão. Isto distingue diagramas de índices, ícones e símbolos. Os significados do diagrama não são fixados. A máquina diagramática ou máquina abstrata não é representacional. Ela não representa um objeto ou situação, mas é instrumental na produção de novos". ${ }^{24}$

\footnotetext{
${ }^{22}$ VAN BERKEL; BOS, 1999, v. 2, p 20.

${ }^{23}$ ARGAN, Giulio Carlo (1966 apud BRANDÃO, 1999, p. 25).

${ }^{24}$ Op. cit., p. 21.
} 
Esta máquina retarda a aparição de signos significantes no processo, permitindo à arquitetura, através deste diagrama, articular uma alternativa diferente da técnica representacional tradicional de projeto, tipológica.

Uma técnica representacional implica, segundo os arquitetos, em uma convergência de concepções conceituais na realidade, acabando por fixar a relação entre idéia e forma, entre conteúdo e estrutura. "Quando forma e conteúdo são sobrepostos, um tipo emerge" 25 .

Assim, uma arquitetura baseada na técnica representacional não conseguiria escapar de tipologias existentes. Já o diagrama, por estar em uma instância além dos signos (ele não é índice, ícone ou símbolo, de acordo com os autores), retardaria esta fixação do tipo no processo.

Como este tipo de mecanismo funciona nos diagramas? Como uma imagem ou qualquer outra referência atua como um diagrama no sentido de eliminar a fixação tipológica?

Os autores mencionam que são buscados conceitos externos à arquitetura a fim de serem introduzidos no processo. Estes conceitos não podem ser apenas sobrepostos no projeto, mas devem ser instâncias de interpretação, utilização, percepção, dentre outras, que "desdobram e trazem à tona aplicações em vários níveis de abstração". ${ }^{26} \mathrm{O}$ conceito trazido ao projeto deve-se ao uso do diagrama como mediador entre o que é abstraído de um campo externo e o que é aplicado ao projeto. Neste ponto existe um limiar sutil entre o que é um conceito e o que é diagrama. Se uma imagem possui uma informação percebida pelos arquitetos de tal modo que possa ser repetida dentro do projeto, de certo modo ela já se apresenta como diagramática, como figura, não imagem ou signo. Ela figura uma relação percebida em um dado momento sob a mobilização do arquiteto. Mas também pode ser nomeada como um conceito percebido.

Por exemplo, a fita de Möebius já se apresenta como uma figura fértil por que, além de representar uma série de signos, possui uma relação interna que, no caso dos arquitetos, foi usada como princípio organizador de um projeto. Mas em outros

\footnotetext{
${ }^{25}$ VAN BERKEL; BOS, 1999, v. 2, p 21.

${ }^{26}$ Ibid, p. 21-22
} 
casos, em projetos mais complexos, outras informações podem ser trazidas, tal como taxa de ocupação de um terreno, freqüência de uso ou movimentos de pessoas sobre uma superfície. Neste caso, estes conceitos são reunidos por um diagrama, um mapa que tem a função de agenciar estes qualidades e, dali fazer emergir outro(s) conceito(s).

\begin{abstract}
"A seleção e aplicação de um diagrama envolve a inserção de um elemento que contenha em sua densa informação algo que nossos pensamentos podem se interessar, algo que é sugestivo, para nos distrair de uma espiralação em direção ao clichê". ${ }^{27}$
\end{abstract}

Porém o diagrama não é selecionado nas bases de uma informação representacional específica, ele não é uma imagem aleatória. A procura pelo diagrama é instigada por questões específicas relacionadas ao projeto em questão, por exemplo, sua localização, programa e construção.

Particularmente no escritório UNStudio, o diagrama é usado constantemente para relacionar efeitos organizacionais. Os diagramas têm um caráter infraestrutural, "sempre podem ser lidos como mapas de movimentos ${ }^{28}$, independentes de suas origens". Na casa Möebius (figura 5.1 e 5.2), por exemplo, o diagrama aparece fundamentalmente como um mecanismo relacional conectando áreas diversas de modos distintos e, portanto, criando conceitos.

\begin{abstract}
"O diagrama da fita dupla traz a organização de dois caminhos entrelaçados que registra como duas pessoas podem viver juntas, ainda que separadas, encontrando em certos pontos, que se tornam espaços compartilhados. A idéia de duas entidades percorrendo suas próprias trajetórias, mas compartilhando certos momentos, possivelmente também revertendo papéis em certos pontos, é ampliada a incluir a materialização do edifício e sua construção". ${ }^{29}$
\end{abstract}

No escritório UNStudio, o movimento que ocorre no processo e que ativa o diagrama em direção a um processo de transformação de conceitos é feito através de duas variáveis: o tempo e a ação. São questões relacionadas a períodos de tempo, tal como quanto tempo os holandeses gastam em diversas atividades durante certo período do dia (usado no projeto UCP Mainport, figura 5.3 e 5.5) ou como se locomovem em um espaço, ações.

\footnotetext{
${ }^{27}$ VAN BERKEL; BOS, 1999, v. 2, p. 22.

${ }^{28}$ Movimento, aqui, deve ser lido de forma mais ampla. Não apenas movimentos físicos, mas abstratos entre o objeto e o projeto - o diagrama faz a mediação deste movimento, desta passagem.

${ }^{29}$ Op. cit. p. 40.
} 


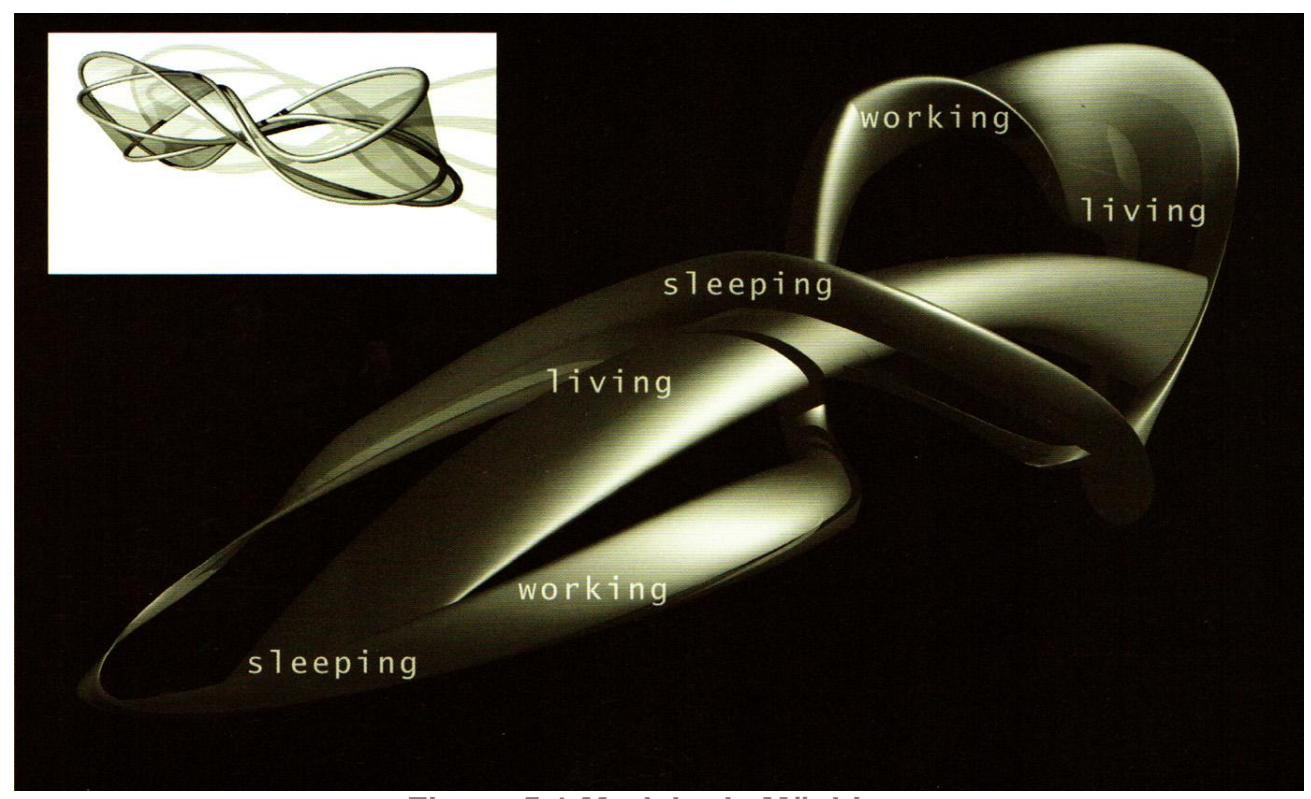

Figura 5.1 Modelo de Möebius.

Dinâmica da casa disposta segundo o diagrama da fita dupla.

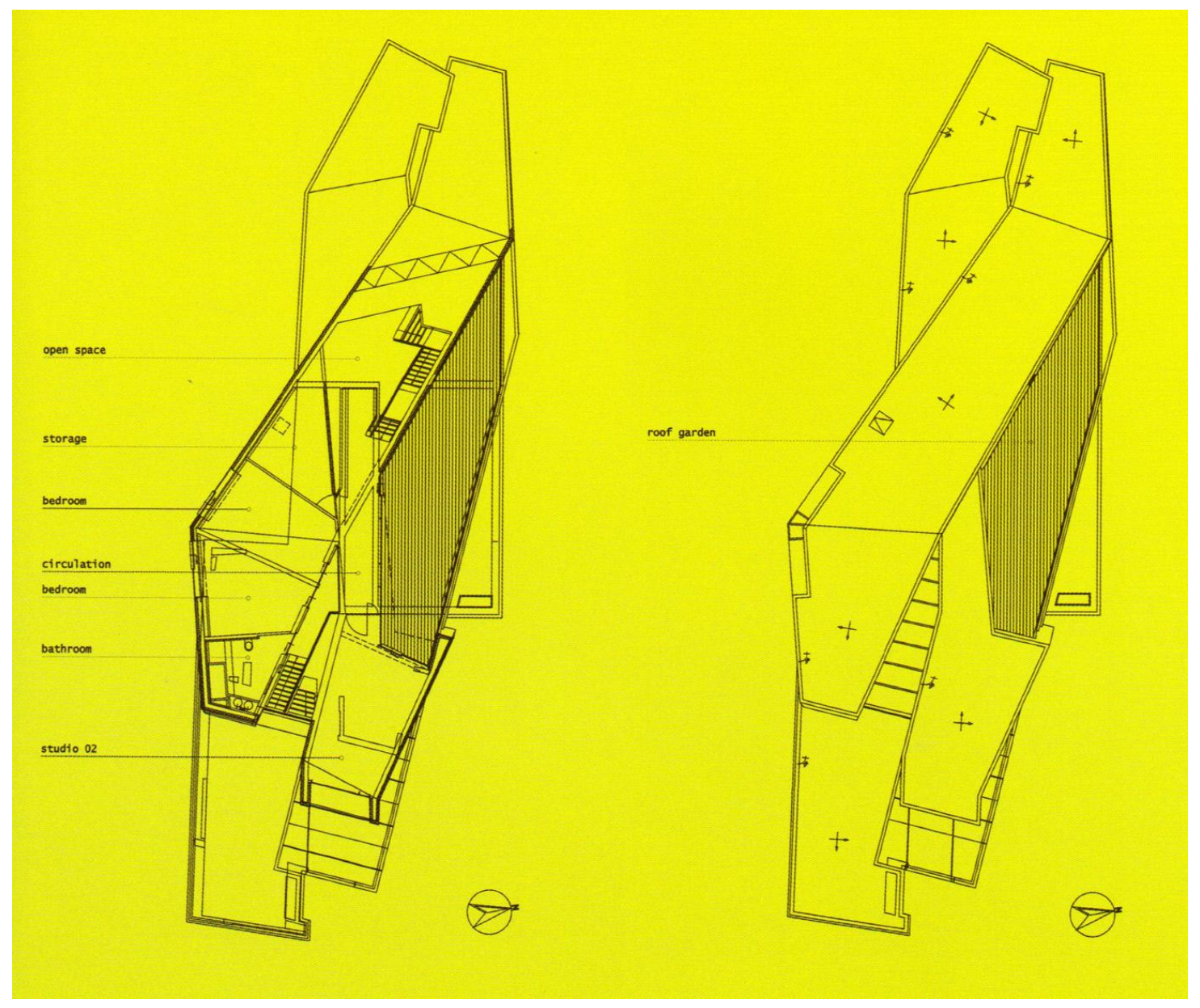

Figura 5.2 Plantas

O percurso que obedece ao diagrama é efetuado pelas duas escadas mostradas, uma acima e outra mais abaixo na planta. 


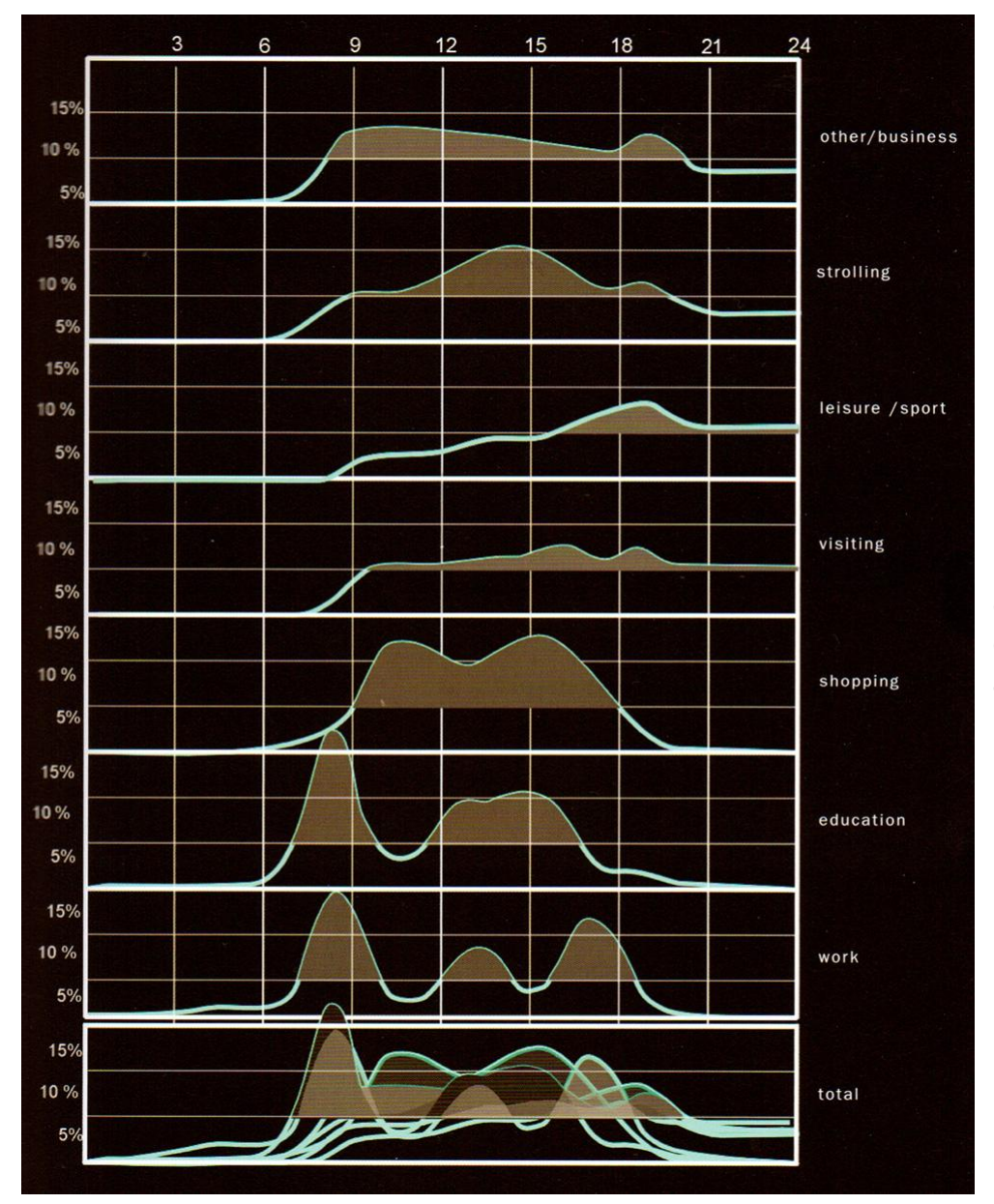

Figura 5.3 UCP Mainport:

"Como os holandeses ocupam seu tempo" durante um dia. Tempo $x$ atividade.

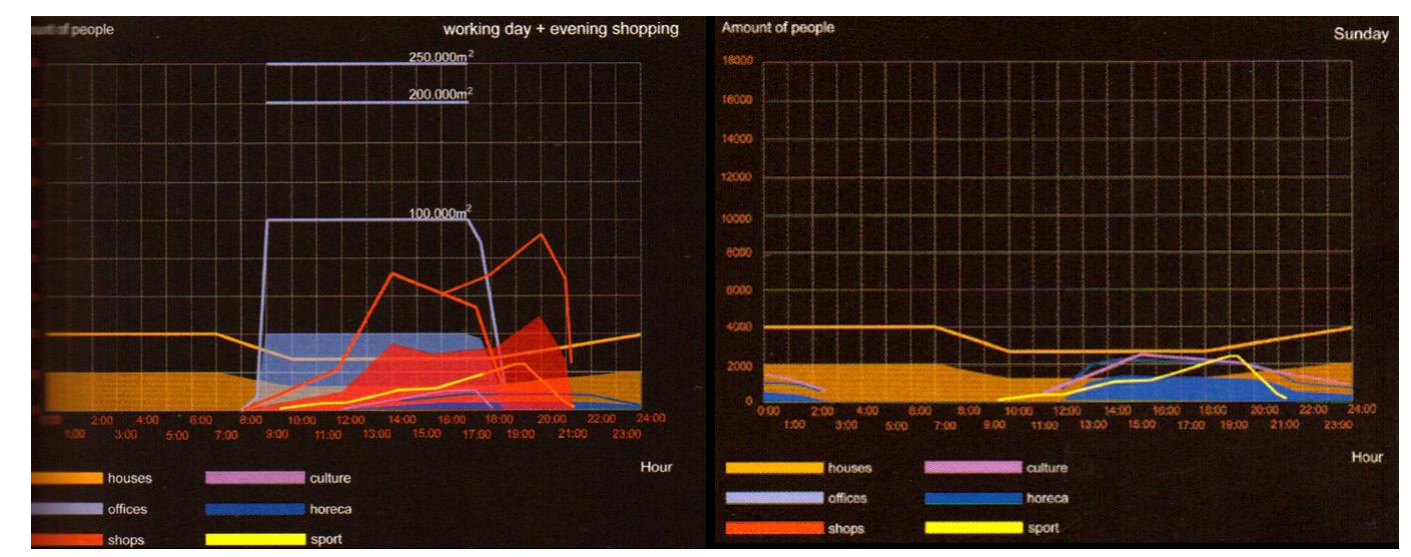

Figura 5.4 Planejamento Urbano em Nieuwegein, 1997-1998.

Quantidade de pessoa/ hora na região durante uma semana (dias úteis e domingo)

Antes do trabalho se transformar em tipologia, um diagrama, rico em sentido, repleto de movimento potencial e carregado com estrutura, que conecta a alguns aspectos importantes do projeto, é encontrado. As propriedades específicas deste diagrama lançam uma nova luz ao trabalho. 

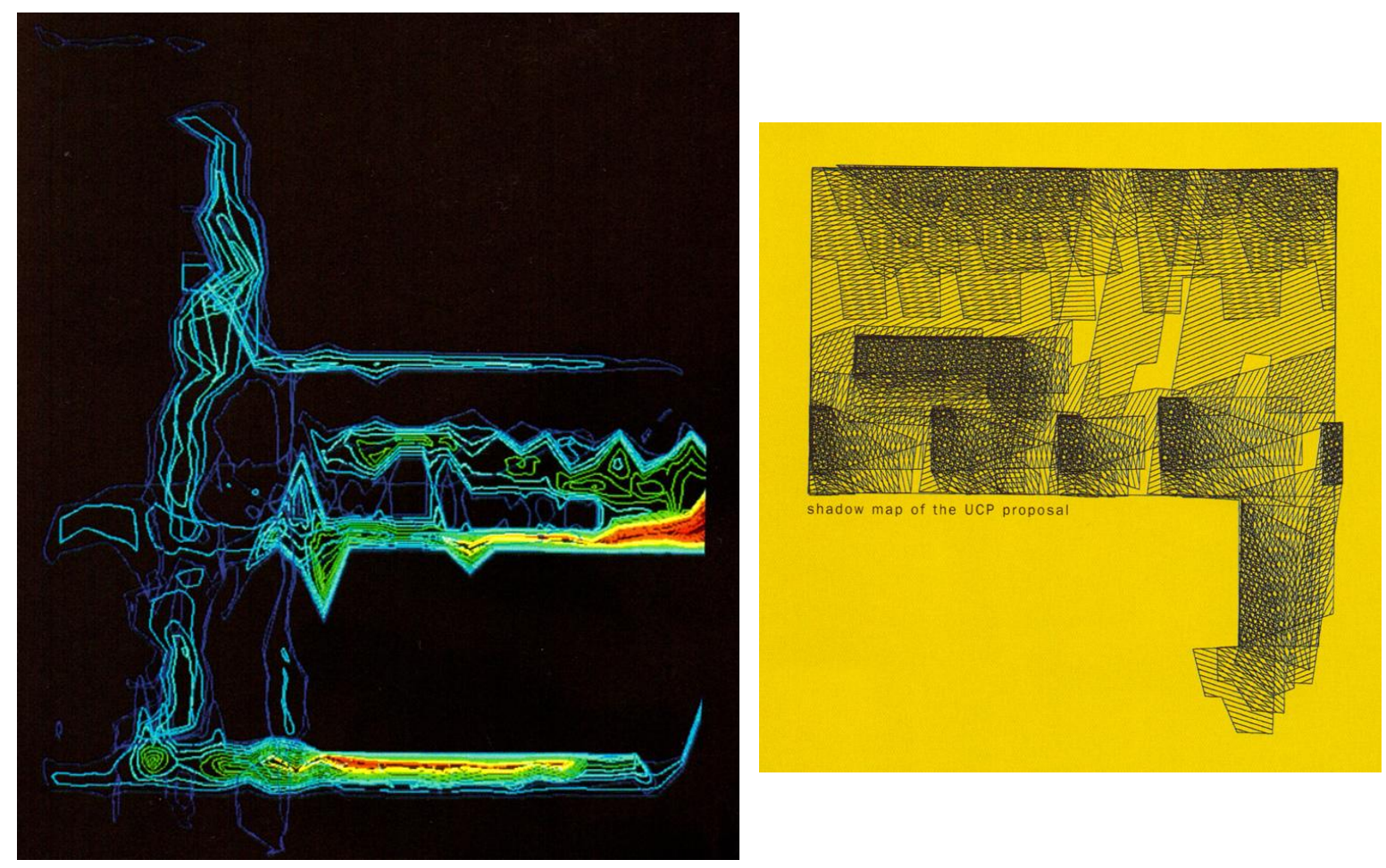

Figura 5.5 UCP Mainport, Utrecht, 1997.

Estudo de fluxo de pessoas e mapa de sombras

Então, a imagem significante que o escritório define como diagrama deve ser entendida diferentemente do conceito de "monumento" Argan. O diagrama, nesta nova arquitetura é visto como um "buraco negro ${ }^{30 "}$. Assim como a astrofísica afirma, um buraco negro converte tudo em volta de si em direção ao seu interior em velocidades imensas de tal modo que atém mesmo a luz é trazida. Do mesmo modo faz o diagrama com o tema. Ele é trazido ao diagrama, converge e mantém uma unidade essencial no projeto, de modo a manter a relação diagrama-conceitopragmática. O diagrama se torna onipresente no processo de projeto. Como resultado, ao contrário do que se parece, o trabalho se torna não-fixado; novas direções e novos sentidos são despertados porque os signos são desestruturados pelos mecanismos ou comportamentos sugeridos pelo diagrama. Ele opera como um ardil, que radicalmente altera o curso do projeto, transformando e liberando a arquitetura. ${ }^{31}$

\footnotetext{
${ }^{30}$ Este tema é desenvolvido por Deleuze e Guattari em torno dos romances de Marcel Proust. Cf. DELEUZE, Gilles; GUATTARI, Félix. Mil Platôs. v. 3. São Paulo: Editora 34: 1996.

${ }^{31}$ Sobre transformações diagramáticas, Cf. DELEUZE; GUATTARI, 1995b, p. 93
} 
Van Berkel e Bos ainda apresentam seus modelos projetivos ${ }^{32}$ como $^{2}$ mecanismos que contém informações (como as de um terreno) em um nível abstrato para serem usadas durante o processo, ajudando a verificação dos passos seguintes aos princípios e propostas do modelo. Diferente dos modelos discutidos no início deste capítulo, estes são gerados por informações trazidas ao projeto e não contém, a priori, significado definido. Eles são o resultado do agenciamento diagramático.

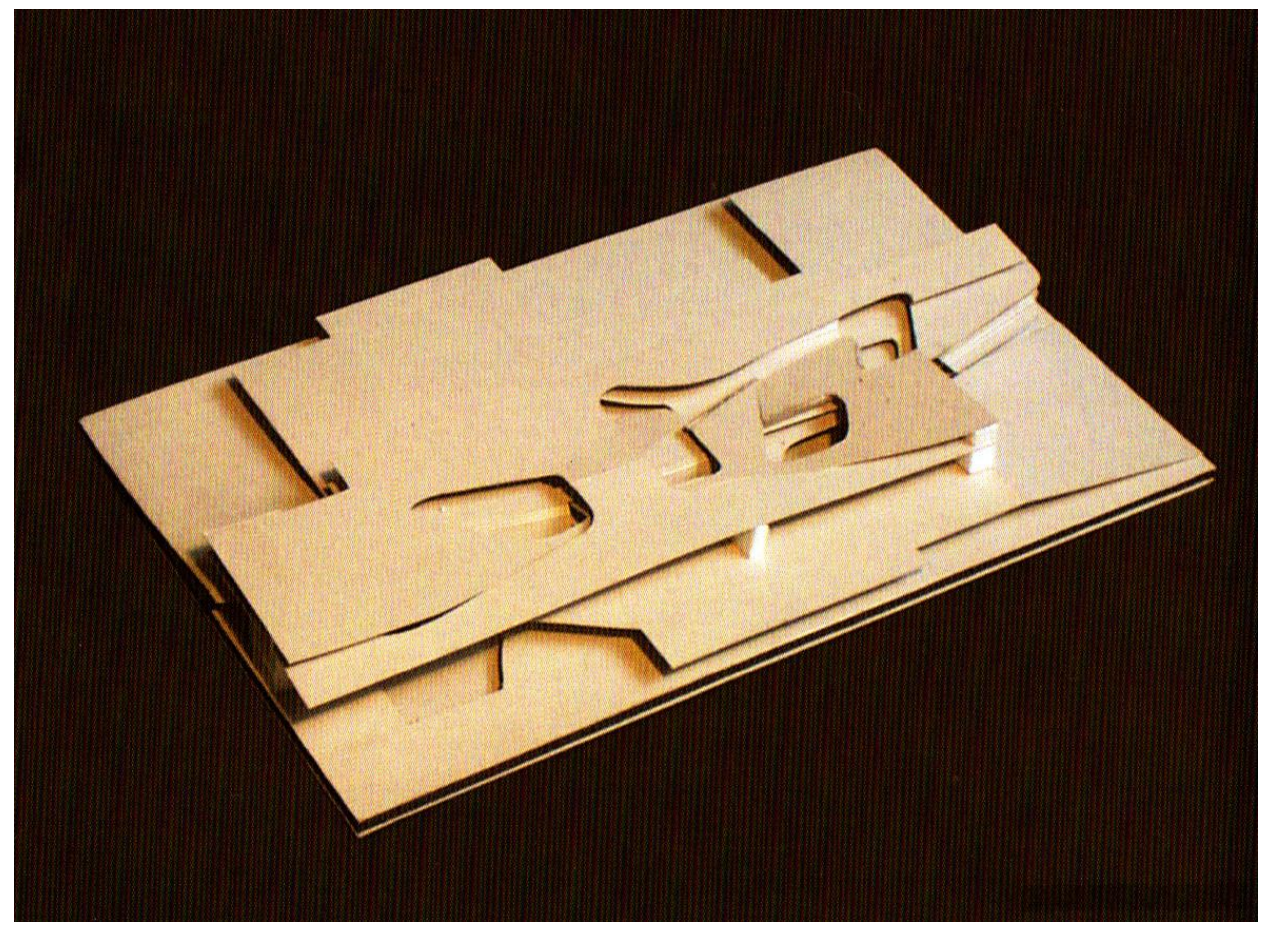

Figura 5.6 Modelo do UCP Mainport

"em arquitetura, nós nos esforçamos em manter a parte textual do modelo projetual mínima e também em desenvolver um modelo baseado em imagens, o qual estabelece que as instruções que normalmente formam 0 corpo do modelo projetual estão implícitas, mais do que explícitas". ${ }^{33}$

Ben van Berkel e Caroline Bos publicaram no ano de 2006 o livro "Design Models" que aparece como uma releitura de seus processos anteriores, mas ainda movidos pelo questionamento que envolve arquitetura, sociedade e tecnologia. Sobre o processo diagramático, os autores mencionam que o ano de 1990 foi o auge de seu interesse sobre diagrama e este era um meio pelo qual eles poderiam fugir da tipologia, mas não para evitar formas já conhecidas, mas porque as tipologias até então realizadas não davam conta das novas questões da sociedade.

\footnotetext{
32 "Design Models"

${ }^{33}$ VAN BERKEL, BOS, 2006, p. 19.
} 
"A regra do diagrama era gerar idéias e encontrar inspiração em alguma coisa puramente organizacional ao invés de iconográfico ou metafórico, e representar um pensamento forte, ainda não completamente racionalizado, um potencial conceitual. Até onde entendemos, o principal requerimento era escapar de tipologias pré-existentes, não por causa da necessidade de ser 'original', mas porque nós sentíamos que tais tipologias já não providenciavam soluções às situações e demandas contemporâneas" . ${ }^{34}$

"Diagramas tipicamente condensam informação, e quando diagramas apropriados pré-existentes não eram encontrados prontamente, nós tínhamos que aprender a encontrar o nosso próprio. Então nós começamos a construir diagramas que (re)definiram estruturas urbanas como territórios de mobilidade e programas como locais de acesso popular. Estes diagramas estavam intencionados a mostrar o que estava de fato acontecendo em um local[...]".

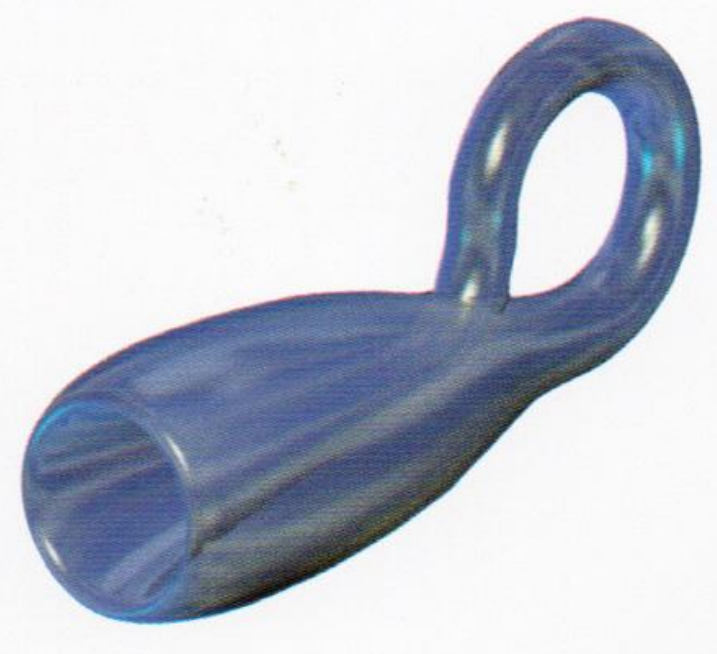

Figura 5.7 Garrafa de Klein

Apesar de mencionarem o diagrama com o caráter "de inspiração", os arquitetos descrevem sua metodologia diagramática de outra maneira:

"[A fim de] desenvolver seu próprio diagrama, nós verificamos, começa com a definição de seus parâmetros. Definindo categorias de usuário, por exemplo, em relação a parâmetros territoriais e temporais, nós gerenciamos a construção de parâmetros complexos, ingredientes arquitetônicos reais, trabalháveis, fora da leve noção de fluxo. Os diagramas que construímos tendiam a acentuar os efeitos da interação entre diferentes atores. Esta aproximação relacional à diagramação gerou novas percepções no potencial de desenvolvimento de locais de uma maneira completa".

Ora, a fim de compreender e gerar outros significados além de uma mera tipologia, o processo de alimentação de um mapa de relações recai no conceito de máquina abstrata, o processo de diagramação tratado pela filosofia de Deleuze e Guattari. Talvez o processo seja movido, em alguns projetos, por este caráter de

\footnotetext{
${ }^{34}$ VAN BERKEL; BOS, 2006, p. 15.

${ }^{35}$ Ibid., loc. cit.
} 
inspiração, mas poderemos rele-lo como uma motivação interna do arquiteto na percepção de linhas de ação de uma figura, uma imagem fértil.

O que acaba por acontecer no processo de van Berkel e Bos é uma definição de diagramas-modelos que foram selecionados como elementos-chave em seus projetos. Assim eles afirmam que, depois de anos de estudo sobre o que e quando é um diagrama, chegaram a alguns modelos de diagramas que foram usados em seus projetos. Porém, como estes diagramas estão em um campo abstrato, são conceitos puros e, deste modo, não caem no problema de repetição tipológica.

\begin{abstract}
"nós começamos a descobrir uma maneira de usar repetição no projeto arquitetônico de um modo abstrato e significativo. Durante os últimos três anos, nós usamos e re-usamos um número de diagramas, e encontramos certos diagramas que podem ser manipulados e aplicados de diferentes maneiras. Assim, a fita de Möebius, sua variante tridimensional a garrafa de Klein, e o trevo, são variações do mesmo modelo matemático, usado de modos diferentes em projetos diferentes". ${ }^{36}$
\end{abstract}

Van Berkel e Bos afirmam que a escolha feita pela topologia, por estes modelos topológicos, deriva do interesse do grupo na infra-estrutura da arquitetura, mais precisamente no modo que um edifício pode ser pensado através do percurso que se faz dentro dele. As imagens de hoje se constroem como bidimensionalidades através de uma signagem ${ }^{37}$ penetrante, criando uma acomodação indevida no espectador.

Assim, tanto a fita de Möebius como a garrafa de Klein (e outros modelos diagramas) que usaram, foi uma maneira de realizar espaços caleidoscópicos, ativar o olho e o cérebro enquanto, ao mesmo tempo, os ajudava a fundir espaços de diferentes usos e durações. ${ }^{38}$

Os edifícios devem criar uma "imagem posterior" ${ }^{39}$ aquilo que é observado e repercute.

\footnotetext{
${ }^{36}$ VAN BERKEL, BOS, 2006. p.15-16.

${ }^{37}$ Ao invés de se criar signos através de uma imagem, um signo cria imagens, não por uma linguagem, mas por uma signagem. Cf PIGNATARI, Décio. Semiótica da Arquitetura. Cotia, Ateliê Editorial: 2004. 3 ed.

${ }^{38}$ Op. cit., p. 377.

39 "After Image" Cf. VAN BERKEL; BOS, 2006, p. 370-379.
} 
[Considerações Finais] 


\section{Considerações Finais}

"Edifícios já foram construídos sem desenhos, mas a arquitetura nela mesma vai além do mero processo de edificação. As complexas demandas culturais, sociais e filosóficas desenvolvidas ao longo dos séculos fizeram da arquitetura uma forma de conhecimento em si e por si. Da mesma maneira que cada forma de conhecimento usa modos diferentes de discurso, há também importantes expressões arquitetônicas que, apesar de não necessariamente construídas, nos informam com muito mais exatidão sobre a situação da arquitetura, suas preocupações e suas polêmicas, que os próprios edifícios de seu tempo". Bernard Tschumi - Arquitetura e Limites I

O diagrama é um signo relacional e na arquitetura aparece como a primeira instância a operar precisamente entre a forma e a palavra ${ }^{1}$.

Percebemos que os autores tratados aqui, como Deleuze, Foucault, Derrida, Lacan, Eisenman e Ben Van Berkel poderiam ser reunidos, além de outras coisas, pelos relacionamentos, pela analogia. Lacan com topologia, Freud em Derrida através do bloco místico de escrita, Peirce e Deleuze com suas referências matemáticas.

A princípio, a relação de uma ciência com outra através de metáforas, analogias, aplicação direta de conceitos nos lembra a questão da autonomia das disciplinas. No nosso caso, uma condição completamente autônoma do processo criativo seria semelhante ao desenvolvido por Eisenman na decomposição de cubos. Ali, de acordo com sua tentativa de emancipação da arquitetura, a linguagem arquitetônica era auto-referente e hermética, instaurada sobre si mesma.

Sabemos que a arquitetura é múltipla e um hermetismo deste modo cria apenas a aparência de uma condição autônoma, uma vez que a arquitetura é múltipla e está inserida em um diagrama que a religa constantemente em outros pontos além do seu próprio.

A arquitetura diagramática contemporânea, por outro lado, é extremamente dependente. É na elevação de temas externos e supressão do desejo do arquiteto

\footnotetext{
1 SOMOL, R. E. Dummy Text, or The Diagrammatic Basis of Contemporary Architecture. In EISENMAN, 1999, p. 8.
} 
que ela instaura. Não diremos em uma dependência ou autonomia de significação, mas de autonomia para ser gerada.

O que acontece na implementação de um diagrama não é somente uma ligação entre o que é pensado e o que é feito, mas uma alteração no próprio discurso da obra. Ao observarmos a casa Möebius do UNStudio, podemos ver o momento que a interferência do diagrama matemático é também uma alteração espacial no edifício.

Assim, diremos que existe um diagrama no Pantheon e provavelmente perceberemos um na basílica de São Pedro de Michelangelo. O que acontece nesta basílica, por exemplo, é a alteração de um diagrama gótico, de Bramante, para um diagrama maneirista de Michelangelo. Tal diagrama é invisível, mas está impregnado na arquitetura. O que se sente estando em uma cela ou na torre do panóptico são afetos, sentimentos de um diagrama propiciado pela expressões.

No Guggenheim de Nova York, de Frank Lloyd Wright, podemos estabelecer um, espiralado, assim como na Biblioteca de Babel de Borges poderemos encontrar outro.

Tal como Braham defende ${ }^{2}$, "arquitetos produzem diagramas, não edifícios". O que entendemos nessa dissertação é existência do diagrama como essência de um processo de pensamento. Assim, o hipoícone trazido por Peirce ainda pode ser entendido nestes procedimentos contemporâneos, mas de modo abstrato. Este é o momento que Deleuze e Guattari aparecem definindo essa abstração nas relações como uma máquina abstrata. Mas ambos os conceitos operam sob o tema da relação ${ }^{3}$.

Relacionar é diagramar. O que sugerimos nessa dissertação é a distinção entre essa essência relacional e sua semântica, ou melhor, seu conteúdo e a expressão. O que essa dissertação trouxe, foi o entendimento de que mecanismo relacional do diagrama é operado na arquitetura de distintas formas.

\footnotetext{
${ }^{2}$ After Typology, the suffering of diagrams. In Architectural Design: Contemporary Processes in Architecture. 70.3 p 9-11

${ }^{3}$ BRANDÃO, 2001, ainda vai além e menciona que os dois sistemas são semióticas.
} 
Quando falamos de panóptico, não falamos do edifício, mas da máquina abstrata que o constitui e que pode ser observada em outras instituições. ${ }^{4}$

Assim, seria mais familiar falarmos em panopticismo - a expressão diagramática que compõe a arquitetura junto com uma matéria não-formada: observação, vigilância, reclusão, controle, etc.

Uma imagem se converte em diagrama a partir do momento em que a instrumentalizamos ${ }^{5}$, ou seja, acionamos o mecanismo no momento que a dotamos de força expressiva.

Quando Berkel e Bos mencionam o uso da fita de Möebius como diagrama, estão dizendo que daquela imagem retiram um comportamento ou uma essência que é transferida ao projeto. Do mesmo modo com o diagrama que Deleuze menciona em Bacon (talvez este discurso seja mais apropriado para nós porque também transita no âmbito de criação artística).

Por sua vez, Eisenman adota um diagrama distinto. Ele cria seu próprio diagrama através de sobreposição de imagens.

Enquanto Berkel utiliza uma ou mais criando uma arquitetura icônica, Eisenman, na junção de mapas, imagens, informações históricas ou o que mais for apropriado, cria um diagrama que significa por rastros de outros mapas e fornece novos vestígios a serem assimilados pelo arquiteto em direção a definições no projeto. Podemos falar que ambos os conceitos são máquinas no momento em que acionam um mecanismo perceptivo no arquiteto e no usuário.

Poderíamos considerar que os diagramas apresentados neste trabalho, assim como os termos relacionados (adjetivos, advérbios e verbos - diagramático, diagramaticamente, diagramar) estão sob o conceito de diagrama que Peirce levanta no século XIX. O diagrama como ícone, um signo relacional.

Por vezes tivemos Eisenman falando sobre seus diagramas de casas, ou seja, imagens; tivemos van Berkel \& Bos do UNStudio falando de imagens com carga significante infinita (relações icônicas geradas) e Foucault citando Bentham como uma arquitetura-diagrama de vigilância. Até mesmo Deleuze, o filósofo da

\footnotetext{
${ }_{5}^{4}$ Cf. D\&G, 1997, p 228.

${ }^{5}$ Berkel, quaderns $p 75$.
} 
diferença, com um conceito aparentemente distinto de diagrama, mas que repete um conceito de um mapa de relações.

Poderíamos dizer que essa qualidade do diagrama, de relacionar é pura função. $O$ modo que esta função relacional opera é sua dramatizaçao ${ }^{6}$. A expressão do diagrama varia em cada caso, mesmo se orientada sob um objetivo.

O que temos em comum tanto em Deleuze, Derrida, Guattari, Eisenman e van Berkel+Bos é um manifesto contra a tipologia. A filosofia traz uma critica à dualidade signo-significado da lingüística estrutural (o que os nomeou como pós-estruturalistas pelos americanos). Eisenman aparece contra a forma moderna de pensar a arquitetura através de um formalismo autoral e van Berkel+Bos trazem consigo a insatisfação de cânones projetuais repetentes.

Um diagrama, no entendimento de Berkel e Eisenman (filtrados de toda argumento secundário para fins dessa observação) poderia ser resumido em uma vontade de significância. Tal como a imagem posterior ${ }^{7}$ de van Berkel ou a presentidade (a figuração parcial de Eisenman), o conceito de diagrama provavelmente teria duração restrita em seus discursos se não estivesse sempre conectado ao conceito de significância além de signos, além de um conceito de interpretação sígnica explícita ${ }^{8}$.

Assim, podemos dizer que o diagrama, fundamentalmente, é um mecanismo de geração de conceitos.

\begin{abstract}
"Um conceito não é um mero ajuntamento de particulares - isto ocorre apenas com suas espécies mais cruas. Um conceito é a influência viva sobre nós de um diagrama, ou ícone, com cujas várias partes entre em conexão, no pensamento, um número igual de sentimentos ou idéias". ${ }^{9}$
\end{abstract}

Talvez possa ser dito que essa dissertação nada fez além de criar um mapa sobre o qual foram expostos os conceitos. Se esse mapa os desloca e os transforma em outros conhecimentos futuros, não sabemos, mas se o fizer, agradaria os franceses.

\footnotetext{
${ }^{6}$ Cf. Capítulo 3 dessa dissertação.

${ }^{7}$ After Image em van Berkel. Presentiness em Eisenman.

${ }^{8}$ Poderíamos desenvolver o tema da hermenêutica neste momento, mas, por precaução, iremos guardá-lo para discussões futuras.

${ }_{9}^{9}$ PEIRCE, Charles S. CP 7.467
} 
[Bibliografia] 
Bibliografia

Architectural Record, volume 81, junho 1937.

BECHMANN, Roland. Villard de Honnecourt: la penseé technique au XIII siècle et sa communication. Paris, Picard Éditeur: 1993.

BORGES, Jorge Luis. A História da Eternidade. São Paulo, Editora Globo: 2001a. . O Elogio da Sombra. São Paulo, Editora Globo: 2001b.

BOSI, Alfredo. História concisa da literatura brasileira. São Paulo: Cultrix, 1999.

BRANDÃO, Carlos Antônio Leite. A formação do homem moderno vista através da arquitetura. Belo Horizonte: Editora UFMG, 1999. - Os modos do discurso da teoria da arquitetura. Cadernos de Arquitetura Ritter do Reis. v. 3, p. 17-43, Porto Alegre, Ritter do Reis: 2001.

CAMPOS, Haroldo. Ideograma: lógica, poesia, linguagem. São Paulo, EdUSP: 2000.

CRAIA, Eladio. O VIRTUAL: destino da ontologia de Gilles Deleuze. Revista de Filosofia, Curitiba, v. 21 n. 28, p. 107-123, 2009.

DAVIDSON, Cyntia. Tracing Eisenman: Complete Works. New York, Rizzoli: 2006.

DELEUZE, Gilles. Diferença e Repetição. São Paulo, Graal Editora: 2006a. . Foucault. São Paulo, Editora Brasiliense: 2006b.

. Francis Bacon: A Lógica da Sensação. Rio de Janeiro, Jorge Zahar Ed., 2007.

; GUATTARI, Félix. Mil Platôs: capitalismo e esquizofrenia. Vol.1, Rio de Janeiro, Editora 34: 1995a.

. Mil Platôs: capitalismo e esquizofrenia. Vol.2, Rio de Janeiro, Editora 34: 1995b. 
. Mil Platôs: capitalismo e esquizofrenia. Vol.5, Rio de Janeiro, Editora 34: 1997.

. O que é Filosofia?. Rio de Janeiro, Editora 34: 1992.

EISENMAN, Peter. Cardboard Architecture, castelli di carte. in: Casabella ํㅜ 386, fev. 1974 p 17-29

. Dall'oggetto alla relazionalità: la casa del Fascio di Terragni. Casabella. n. 344, . p. 38-41, 1979.

. Diagram Diaries. London, Tames \& Hudson: 1999.

. The Formal Basis of Modern Architecture. Lars Müller Publishers: 2006.

El Croquis; Ben van Berkel, 1990 -1995. Número 72, Madrid: 1995.

; Peter Eisenman, 1990 -1997. Número 83, Madrid: 1997.

FLÓRIO, Wilson. $O$ uso de ferramentas de modelagem vetorial na concepção de uma arquitetura de formas complexas. Tese de Doutorado, São Paulo, FAUUSP: 2005.

FRAMPTON, Kenneth. Historia Crítica da Arquitetura Moderna. São Paulo, Martins Fontes: 2008

GANDELSONAS, Mario. "Linguistics in Architecture", in Casabella, fev/1973.

GUATELLI, Igor Guatelli: A Desconstrução em Arquitetura: 1960 ou 1990?., São Paulo, FAU USP: 1998. Dissertação de mestrado.

GUATELLI, Igor. O(s) lugar(es) do Entre na Arquitetura Contemporânea., São Paulo, FFLCH USP: 2005. Tese de Doutorado.

GUATTARI, Felix, On Machines. Journal Of Philosophy And The Visual Arts, n. 6, p. 8-12,1995.

HABERMAS, Jürgen. O Discurso Filosófico da Modernidade. Martins Fontes, São Paulo: 2002.

HARVEY, David. Condição Pós-moderna. São Paulo, Ediçoes Loyola: 1996. 
JORGE, Ana Maria Guimarães. Heurística da Introvisão: Prolegômenos ao Conceito de Diagrama na Obra de Charles Sanders Peirce. Dissertação de Mestrado. São Paulo, Pontifíca Universidade Católica de São Paulo: 1999.

LACOMBE, Octavio L. M. Diagramas Digitais: pensamento e gênese da arquitetura mediada por tecnologias numéricas. Tese de doutorado, São Paulo, FAU-USP: 2006.

LEVI-STRAUSS, Claude. Antropologia Estrutural. Rio de Janeiro, Tempo Brasileiro: 1985. $2^{\mathrm{a}}$ edição. Tradução Chaim Samuel Katz e Eginardo Pires.

LOTUS International, número 127. Milan, Lotus Editorale: 2006.

NESBIT, Kate. Uma nova agenda para a arquitetura: antologia teórica (19651995). São Paulo, Cosac Naify: 2006

MEZAN, Renato. Freud: pensador da cultura. São Paulo, Companhia das Letras: 2006.

MONEO, Rafael. Theoretical Anxiety and Design Strategies in the work of eight contemporary architects. Barcelona, ACTAR Editorial: 2004.

OCKMAN, Joan (ed.) EIGEN, Edward (col.). Architecture Culture 1943 -1968: A Documentary Anthology. New York: Rizzoli International Publications: 1993.

OPPOSITIONS READER. New York, Princeton Architectural Press: 1998.

PAl, Hyungmin. The Portifolio and the Diagram: Architecture, discourse and modernity in America. Cambridge, MIT press: 2002.

PALLADIO, Andrea. Quattro libri dell'architettura; riproduzione in fac-simile dell'edizione de 1570 a cura di ulrico hoepli. Milano, Hoepli: 1945

PEIRCE, Charles S. Semiótica. São Paulo, Perspectiva: 2008.

Collected Papers of Charles Sanders Peirce. 8 volumes., Cambridge, Harvard University Press: 1978 
. New Elements of Mathematics, ed. by Carolyn Eisele, 4 volumes., Mouton, The Hague, 1976.

PERICÁS, Bernardo. A batalha de Chigado. Revista Cult, São Paulo, n 126, p. 4446, 2008.

ROBERTS, Don D. Existential Graphs of Charles S. Peirce. Mouton de Gruyter, The Hague: 1973.

ROWE, Colin. The Mathematics of the Ideal Villa and Other Essays. Cambridge, MIT Press: 1987.

SANTAELLA, Lúcia. A teoria geral dos signos - semiose e autogeração. São Paulo, Atica: 1995

SAUSSURE, Ferdinand de. Curso de lingüística geral. São Paulo, Editora Cultrix: 2006.

SOLÀ-MORALES. Diferencias. Barcelona, Editorial Gustavo Gili: 2003.

SOMOL, R.E. Texto sonso, ou a base diagramática da arquitetura contemporânea. In Risco: Revista de Pesquisa em Arquitetura e Urbanismo. Número 5, São Paulo, EESC-USP: 2007. Tradução Octavio Lacombe.

SPERLING, David M. Arquiteturas contínuas e topologia: similaridades em processo. Dissertação de mestrado, São Carlos, EESC-USP: 2003.

VAN BERKEL, Ben van. Entre el ideograma y la imagen-diagrama. Quaderns d'Arquitectura i Urbanisme, Barcelona, Espirales: 1999. ; BOS, Caroline (ed.). MOVE. Amsterdam, UN Studio \& Goose Press: 1999. . UN Studio Design Models - Architecture Urbanism Infraestructure. New York, Rizzoli: 2006.

Dicionários:

DUBOIS, et. all. Dicionário de Lingüística. Cultrix, São Paulo: 1997. 11ํㅡㄹ ed. 
http://michaelis.uol.com.br/moderno/ingles/index.php

http://dictionary.babylon.com/

http://www.wordreference.com/

http://dictionary.reference.com/

\section{Websites:}

EISENMAN, Peter

<http://www.cca.qc.ca/en/education-events/71-urgency-2007-rem-koolhaas-andpeter-eisenman>. Urgency. Montreal: 2007. Acessado em: 02/01/10

BERKEL, Ben; BOS, Caroline.

<http://www.unstudio.com/nl/unstudio/media/video/unstudio-documentary>. Acessado em: 20 dez. 2009. 
"Os modos de vida inspiram maneiras de pensar, os modos de pensamento criam maneiras de viver. A vida ativa o pensamento, e o pensamento por sua vez afirma a vida".

Gilles Deleuze 